\title{
PRÊMIO DE EXPORTAÇÃO DA SOJA BRASILEIRA
}

\author{
MAURICIO DE MORAES
}

Dissertação apresentada à Escola Superior de Agricultura "Luiz de Queiroz", Universidade de São Paulo, para obtenção do título de Mestre em Ciências, Área de Concentração: Economia Aplicada

PIRA CIC A B A

Estado de São Paulo - Brasil

Dezembro - 2002 


\title{
PRÊMIO DE EXPORTAÇÃO DA SOJA BRASILEIRA
}

\author{
MAURICIO DE MORAES
}

Engenheiro Agrônomo

\section{Orientador: Prof. GERALDO SANT'ANA DE CAMARGO BARROS}

\author{
Dissertação apresentada à Escola Superior de \\ Agricultura "Luiz de Queiroz", Universidade de São \\ Paulo, para obtenção do título de Mestre em \\ Ciências, Área de Concentração: Economia \\ Aplicada
}

PIRA CIC A B A

Estado de São Paulo - Brasil

Dezembro - 2002 


\title{
Dados Internacionais de Catalogação na Publicação (CIP)
} DIVISÃO DE BIBLIOTECA E DOCUMENTAÇÃO - ESALQ/USP

\author{
Moraes, Mauricio de \\ Prêmio de exportação da soja brasileira / Mauricio de Moraes. - - \\ Piracicaba, 2002. \\ $90 \mathrm{p.}$ \\ Dissertação (mestrado) - - Escola Superior de Agricultura Luiz de \\ Queiroz, 2002. \\ Bibliografia. \\ 1. Bolsa de mercadorias 2. Exportação 3. Grãos 4. Investimentos 5. \\ Negociação 6. Preço a gríc ola 7. Prêmio 8. Soja 9. Variável estatística I . \\ Título
}

CDD 633.34

"Permitida a cópia total ou parcial deste documento, desde que citada a fonte - $\mathrm{O}$ autor" 
À minha esposa,

Denise,

DEDICO 


\section{AGRADECIMENTOS}

A Deus, pela direção e auxílio em todas as decisões.

Ao professor Geraldo Sant'Ana de Camargo Barros, pela confiança, orientação e amizade. À professora Vania Di Addario Guimarães pelo companheirismo, ajuda e sugestões oferecidas durante o desenvolvimento deste trabalho.

À professora Miriam R. P. Bacchi pela ajuda e sugestões na realização dos testes econométricos. Aos professores do Departamento de Economia Administração e Sociologia (DEAS) da ESALQ/USP pelas oportunidades de aprendizado e amizade.

Aos amigos e colegas do CEPEA pelo suporte e compreensão, especialmente ao Sergio De Zen, pelas sugestões oferecidas no exame de qualificação. Aos colegas de curso de mestrado, pelo apoio e companheirismo. A CAPES, pelo apoio financeiro no início do curso.

A Ademir Honório, SEAB/DERAL, SIMEPAR, entre outros, pelos dados fornecidos e pela atenção dispensada.

À Denise R. de Moraes por todo apoio e amizade, além da correção gramatical

dos textos. A todos que direta ou indiretamente contribuíram para realização deste trabalho. 


\section{SUMÁRIO}

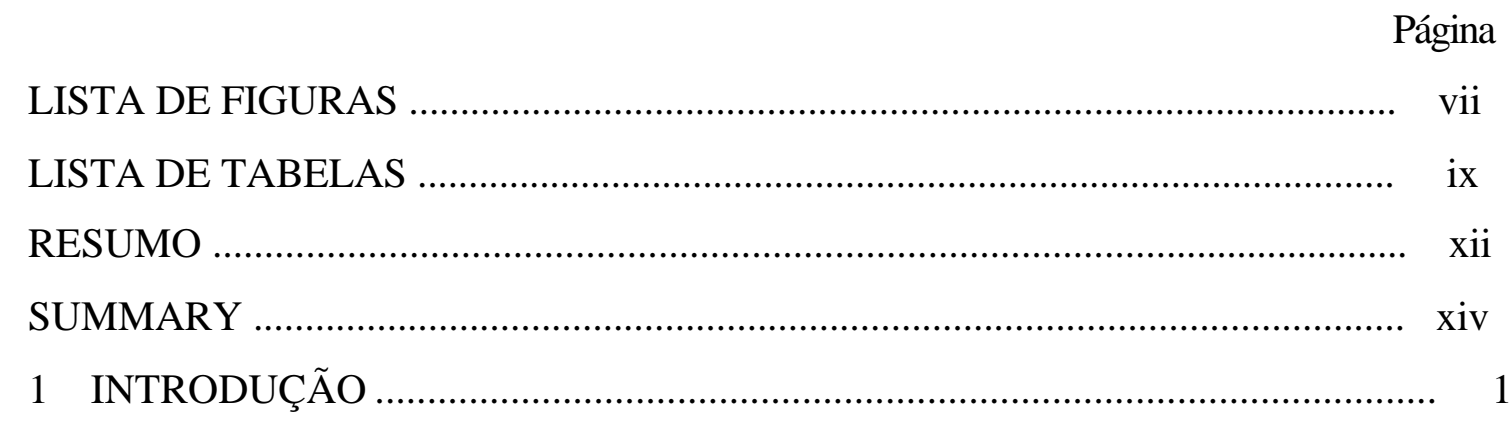

1.1 Problema e sua importância .................................................................... 1

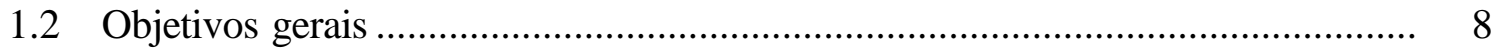

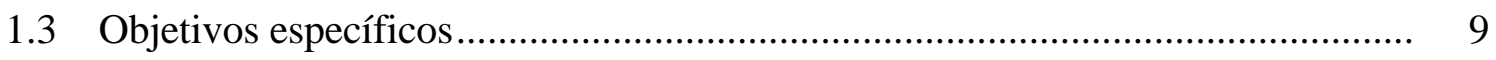

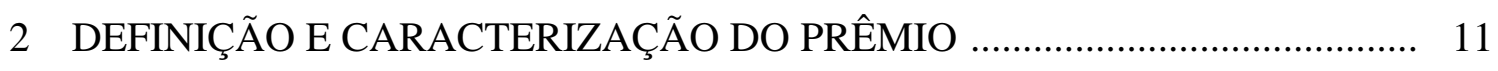

2.1 Definiç̧ão do prêmio ........................................................................... 11

2.2 Agentes que atuam no mercado de prêmio ................................................ 15

2.3 Dimensões do prêmio ........................................................................... 16

2.4 Períodos de negociação do prêmio ................................................................ 17

2.5 Hedge perfeito do prêmio..................................................................... 19

2.6 Prêmio em outros portos brasileiros........................................................ 20

2.7 Operações de Flat Price ............................................................................ 20

2.8 Mecanismo de formação do prêmio .............................................................. 20

2.8.1 Determinação do valor do prêmio pela ótica do exportador .......................... 21

2.8.2 Determinação do valor do prêmio pela ótica do importador ............................ 27

2.8.3 A soja transgênica e o prêmio .................................................................... 33

2.8.4 Determinação do prêmio: exportador versus importador .............................. 34

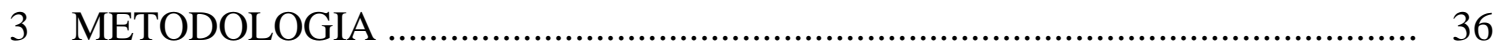

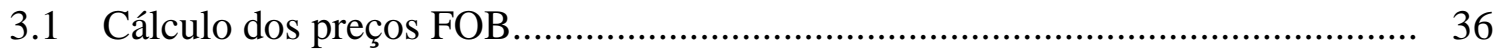




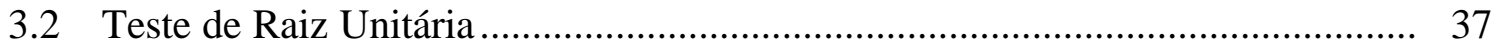

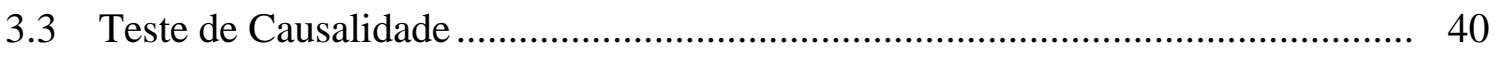

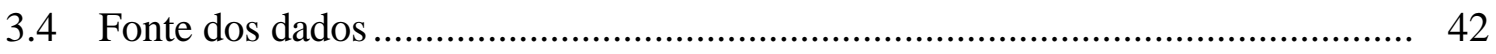

4 RESULTADOS E DISCUSSÃO .............................................................. 43

4.1 O mercado de prêmio .......................................................................... 43

4.1.1 O preço FOB Paranaguá ........................................................................... 43

4.1.2 Padrão sazonal do prêmio ................................................................... 50

4.1.3 Importância relativa do prêmio ................................................................ 53

4.1.4 Comportamento do prêmio para os principais meses de embarque da soja

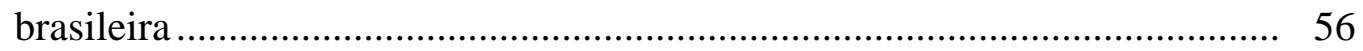

4.2 Modelo teórico na determinação do prêmio..................................................... 59

4.3 Testes de Raiz Unitária .............................................................................. 60

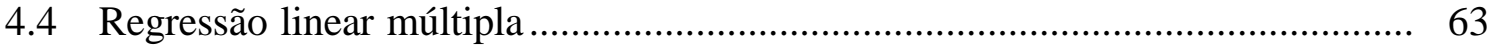

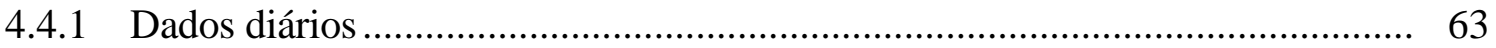

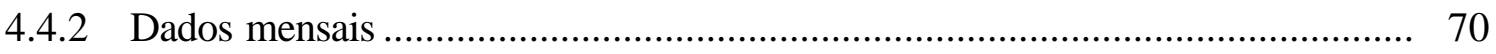

4.5 Teste de causalidade entre as séries FOB e preços da soja em Maringá.............. 78

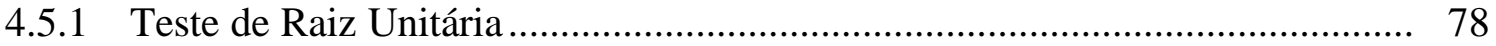

4.5.2 Elasticidade de transmissão de preços ....................................................... 80

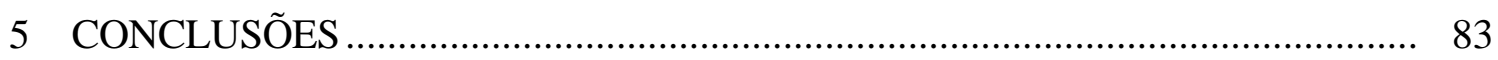

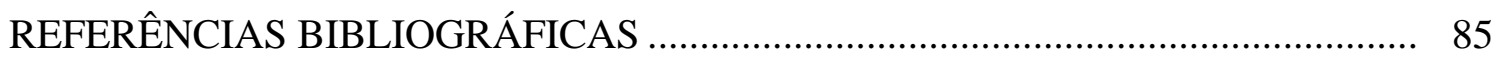

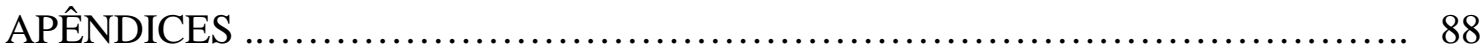




\section{LISTA DE FIGURAS}

Página

1 Participação relativa dos principais países produtores na produção mundial

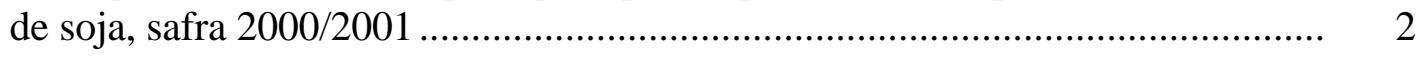

2 Produção e comércio mundial de oleaginosas. Média das safras 2000/01 e 2001/02. Valores em mil toneladas.................................................................

3 Produção e comércio mundial de farelos vegetais. Média das safras 2000/01 e 2001/02. Valores em mil toneladas

4 Produção e comércio mundial de óleos vegetais. Média das safras 2000/01 e 2001/02. Valores em mil toneladas.

5 Evolução do preço FOB Paranaguá (série 1) entre 1996 e 2001. Valores em dólar por saca de $60 \mathrm{Kg}$

6 Evolução do preço FOB Paranaguá (série 2) entre 1996 e 2001. Valores em dólar por saca de $60 \mathrm{Kg}$.

7 Evolução do preço FOB Paranaguá (série 3) entre 1996 e 2001. Valores em dólar por saca de $60 \mathrm{Kg}$.

8 Evolução do preço FOB Paranaguá (série 4) entre 1996 e 2001. Valores em dólar por saca de $60 \mathrm{Kg}$.

9 Evolução do prêmio de exportação da soja em Paranaguá - série 1. Valores em dólar por saca de $60 \mathrm{Kg}$.

10 Evolução do prêmio de exportação da soja em Paranaguá - série 2. Valores em dólar por saca de $60 \mathrm{Kg}$.

11 Evolução do prêmio de exportação da soja em Paranaguá - série 3. Valores em dólar por saca de $60 \mathrm{Kg}$. 
12 Evolução do prêmio de exportação da soja em Paranaguá - série 4. Valores em dólar por saca de $60 \mathrm{Kg}$.

13 Padrão sazonal do prêmio de exportação da soja em grão pelo porto de Paranaguá, Paraná, 1993 a 2001........................................................................ 50

14 Variação percentual do preço FOB devido ao prêmio para série 1 ...................... 54

15 Variação percentual do preço FOB devido ao prêmio para série 2..................... 54

16 Variação percentual do preço FOB devido ao prêmio para série $3 \ldots \ldots \ldots \ldots \ldots \ldots \ldots \ldots . . . . . . .55$

17 Variação percentual do preço FOB devido ao prêmio para série 4 ..................... 55

18 Volume de soja embarcado em mil toneladas............................................ 56

19 Média mensal e desvio padrão do prêmio de exportação da soja em grão pelo porto de Paranaguá, de 1993 a 2002, para embarque em abril

20 Média mensal e desvio padrão do prêmio de exportação da soja em grão pelo porto de Paranaguá, de 1993 a 2002, para embarque em maio.

21 Média mensal e desvio padrão do prêmio de exportação da soja em grão pelo porto de Paranaguá, de 1993 a 2002, para embarque em junho.

22 Média mensal e desvio padrão do prêmio de exportação da soja em grão pelo porto de Paranaguá, de 1993 a 2002, para embarque em julho.

23 Média mensal e desvio padrão do prêmio de exportação da soja em grão pelo porto de Paranaguá, de 1993 a 2002, para embarque em agosto.

24 Representação das relações causais entre as variáveis determinantes do prêmio de exportação da soja (dados diários).

25 Representação das relações causais entre os dados mensais determinantes do prêmio de exportação da soja.

26 Representação das relações causais entre os preços de exportação (séries FOB) e o preço da soja em dolar em Maringá. 


\section{LISTA DE TABELAS}

Página

1 Exportação de soja em grão dos principais países exportadores, média das safras 96/97 a 00/01 e estimativa para a safra 2001/02, em mil toneladas.

2 Importação de soja em grão dos principais países importadores, média das safras 96/97 a 00/01 e estimativa para a safra 2001/2002, em mil toneladas.

3 Cálculo do preço de paridade de exportação da soja em grão para a região de Maringá, Paraná em 18 de março de 2002........

$4 \quad$ Capacidade instalada de processamento de oleaginosas no Brasil em 2001.........

5 Cálculo da rentabilidade das operações de exportação de soja em grão e do esmagamento e exportação de óleo e farelo de soja para uma indústria localizada em Cascavel, Paraná, na segunda quinzena de outubro de 2001.

6 Cálculo da rentabilidade das operações de esmagamento e venda no mercado interno do óleo e farelo de soja para uma indústria localizada em Cascavel, Paraná, na primeira quinzena de outubro de 2001

7 Cálculo da rentabilidade das operações de esmagamento e venda no mercado interno do óleo e farelo de soja para uma indústria localizada em Cascavel, Paraná, em abril de 2001

8 Cálculo da rentabilidade das operações de esmagamento e venda no mercado interno do óleo e farelo de soja para uma indústria localizada em Cascavel, Paraná, em abril de 2001

9 Principais países produtores, consumidores, exportadores e importadores de oleaginosas, média das safras 2000/01 e 2001/02, valores em mil toneladas.......

10 Principais países produtores, consumidores, exportadores e importadores de farelos e farinhas protéicos. Valores em mil toneladas. 
11 Principais países produtores, consumidores, exportadores e importadores de óleos vegetais, média das safras 2000/01 e 2001/02, valores em mil toneladas.

12 Cálculo do valor do prêmio da soja em grão para um importador em Roterdã, abastecendo-se no porto de Paranaguá, Paraná, na segunda quinzena de Março de 2002.

13 Cálculo do valor do prêmio da soja em grão para um importador em Roterdã, abastecendo-se no Golfo do México, EUA, na segunda quinzena de Março de 2002.

14 Cálculo do valor do prêmio da soja em grão para um importador em Roterdã, abastecendo-se no porto de Buenos Aires, Argentina, na segunda quinzena de Março de 2002.

15 Séries diárias de preços FOB: meses de referência para o valor do prêmio de exportação da soja e do vencimento futuro da Bolsa de Chicago.

16 Calendário agrícola da soja nos Estados Unidos, Argentina e Brasil, média dos últimos cinco anos safra.

17 Análise da significância do padrão sazonal do prêmio utilizando-se variáveis binárias.

18 Variáveis importantes na determinação do prêmio de exportação da soja em grão pelo porto de Paranaguá, Paraná.

19 Testes de raiz unitária para as séries com dados diários: prêmio (PREMIO); dias de chuva (CHUVA); taxa cambial (DOLAR); preço interno em dólar do farelo (FARELO); preço interno em dólar do óleo (OLEO); prêmio do farelo (PFARELO); prêmio do óleo (POLEO), cotações do primeiro vencimento da Bolsa de Chicago (CBOT) e cotação do petróleo tipo Brent (PETRO), em nível e na diferença, quando necessário.

20 Testes de raiz unitária para as variáveis com dados mensais: prêmio (PREMIO); precipitação mensal (CHUVA); taxa de câmbio (DOLAR); preço interno em dólar do farelo (FARELO); preço interno em dólar do óleo (OLEO); prêmio do farelo (PFARELO); prêmio do óleo (POLEO); estoque mensal no Brasil (EBRA); estoque mensal na Argentina (EARG); estoque mensal nos Estados Unidos (EEUA); exportações brasileiras (EXBRA); exportações argentinas (EXAR), cotações do primeiro vencimento da Bolsa de Chicago (CBOT) e cotação do petróleo tipo Brent (PETRO), em nível e na diferença, quando necessário. 
21 Relações causais entre o prêmio e suas variáveis determinantes utilizando-se dados diários.

22 Estimativa do prêmio em função das variáveis com dados diários, com o número de defasagens determinadas no teste de causalidade e teste da soma dos coeficientes.

23 Estimativa do prêmio em função das variáveis com dados diários, com cinco defasagens e teste da soma dos coeficientes.

24 Relações causais entre o prêmio e suas variáveis determinantes com dados mensais.

25 Estimativa do prêmio em função das séries com dados mensais (com as defasagens determinadas no teste de causalidade) e teste da soma dos coeficientes. .

26 Estimativa do prêmio em função das séries com dados mensais com cinco defasagens e teste da soma dos coeficientes.

27 Resultado dos testes de Raiz Unitária para o preço da soja em Maringá, PR, e para as séries FOB.

28 Resultado dos testes de Raiz Unitária para o preço da soja em Maringá, PR, e para as séries FOB, na forma logarítmica.

29 Elasticidades de transmissão de preços da soja entre o preço de exportação (séries FOB) e o preço em Maringá, Paraná. 


\section{PRÊMIO DE EXPORTAÇÃO DA SOJA BRASILEIRA}

Autor: MAURICIO DE MORAES

Orientador: Prof. Dr. GERALDO SANT'ANA DE CAMARGO BARROS

\section{RESUMO}

Este trabalho buscou entender o prêmio de exportação da soja em grão no porto de Paranaguá, seu mecanismo de formação, padrão sazonal, as principais variáveis responsáveis pelas oscilações diárias e mensais, bem como determinar qual contrato futuro da bolsa de Chicago e prêmio (preços FOB) estão mais relacionados com os preços internos. Para tanto, foram levantadas através da literatura e entrevistas as variáveis potencialmente significativas para explicar as variações do prêmio de exportação da soja em grão. Adicionalmente foram calculadas séries de preços FOB, que foram posteriormente relacionadas com os preços da soja no mercado interno. Através de testes de causalidade foram definidas as principais variáveis explicativas do prêmio. Estas variáveis foram relacionadas ao prêmio através de regressões lineares, utilizandose dados diários e mensais. O nesmo procedimento foi utilizado para definir a série de preço de exportação mais relacionada com o preço doméstico da soja. Para cada série foi realizado o teste de raiz unitária, objetivando-se verificar a estacionariedade das séries. As variáveis que apresentaram relação causal com o prêmio da soja em grão são: o prêmio do grão defasado, o prêmio do óleo, o prêmio do farelo e o percentual exportado 
através do porto de Paranaguá para a Europa e Ásia. Estas variáveis apresentaram-se positivamente relacionadas com o prêmio, isto é, uma elevação nas variáveis explicativas tende a elevar a variável dependente (prêmio do grão). Por outro lado, o preço interno do farelo, chuva no porto, estoques no Brasil, na Argentina e nos Estados Unidos são negativamente relacionados ao prêmio, isto é, a elevação dessas variáveis tende a reduzir o prêmio. Os fretes internacionais, tendo como proxy o preço internacional do petróleo, a taxa de câmbio e as cotações da bolsa de Chicago não apresentaram relação causal com o prêmio de exportação da soja em grão. Os resultados mostram também que a relação entre as séries de preços de exportação (FOB) e o preço interno da soja é unicausal, com sentido do preço de exportação para o preço interno. Os preços FOB referenciados nos contratos para o primeiro vencimento da bolsa de Chicago apresentaram a maior elasticidade de transmissão de preços, sendo estes os preços de exportação mais bem relacionados com o preço interno da soja. 


\section{BRAZILIAM SOYBEANS EXPORT PREMIUMS}

Author: MAURICIO DE MORAES

Adviser: Prof. Dr. GERALDO SANT'ANA DE CAMARGO BARROS

\section{SUMMARY}

This research analyzed the formation process of the Brazilian soybeans export premiums at Paranaguá port, Paraná, including its seasonal behavior and effects of the main related variables. This study determined which future contract in the Chicago Board of Trade and export premium (which results in the price received by exporters Free on Board Price) is closest to domestic prices. The analysis was accomplished with daily data from 1996 o 2002 and monthly data from 1993 to 2002. Variables potentially relevant were raised through literature review and interviews with exporters, importers and brokers. The effects of these variables were submitted to causality tests, being related to export premiums through linear regression models, using daily and monthly data. The same procedure was used to determine the FOB price most related to internal ones. In order to verify whether the variables are stationary, the series were submitted to Unit Root Tests. The variables that presented causal relationship with the export premium are: soybeans premiums lags, soy-oil premiums, soy-meal premiums and the percentage of exports to Europe and Asia through Paranaguá Port. These variables are positively related to the soybeans premiums, that is, an increase in these independent 
variables led the premium to rise. Soy-meal domestic price, rain intensity in Paranaguá port, inventories in Brazil, Argentina and United States are all negatively related to the soybeans premiums. On the other hand, international petroleum prices (as a proxy to international freights), exchange rate and $\mathrm{CBOT}$ prices did not present causal relationships with soybeans premiums. Results show that export (FOB) prices cause domestics prices. FOB prices referred to first contracts at CBOT showed the largest elasticity of price transmission and, therefore, the strongest relationship with soybeans Brazilian prices. 


\section{INTRODUÇÃ̃O}

\subsection{Problema e sua importância}

Inúmeros trabalhos mostram que os preços domésticos da soja são diretamente afetados pelo comportamento das suas cotações internacionais. Porém, dentre os estudos relacionados ao processo de formação do preço interno da soja, poucos citam a existência do prêmio de exportação. Através deste estudo exploratório e inicial, pretende-se entender o mercado de prêmio de exportação da soja em grão, seu mecanismo de formação e sua relação com os preços praticados no Brasil.

Tosto (1996) e Mafiolleti (2000) mencionam o prêmio na formação dos preços sem, no entanto, inseri-lo como variável explicativa em seus modelos. Aguiar (1990) analisando a formação de preços da soja na indústria brasileira entre 1982 e 1989, utiliza preço $\mathrm{FOB}^{1}$ Porto de Paranaguá, que é dado pela cotação da Bolsa de Chicago (CBOT) somada ao prêmio de exportação ${ }^{2}$. No entanto, esse autor analisa o preço FOB sem desagregá-lo em seus componentes, impossibilitando a análise do efeito do prêmio em separado e também não deixa claro como o preço FOB utilizado foi calculado a partir de uma série de cotações da CBOT e de diversos prêmios disponíveis para uma mesma data. Margarido \& Souza (1998), Margarido \& Machado (2000), Freitas et al (2000) e

\footnotetext{
${ }^{1}$ Free On Board (livre a bordo)

${ }^{2} \mathrm{O}$ prêmio é um fator que pode assumir valores positivos, caso o preço FOB esteja acima da cotação de Chicago ou negativo se estiver abaixo.
} 
Câmara et al (2000) buscam definir as relações entre os preços internacionais e os domésticos sem mencionar a existência do prêmio. Parcell \& Stiegert (1999) e Murova et al (1998) concentram-se em explicar o prêmio a partir da hipótese de que diferenciais de qualidade são responsáveis pela sua existência no mercado interno norte americano.

O fato é que, ainda hoje, o prêmio é uma variável pouco conhecida, mesmo sabendo-se que pode reduzir o preço recebido pelo exportador (FOB) em mais de 5\% e aumentá-lo em mais de $20 \%$, o que pode alterar significativamente a rentabilidade do exportador e do produtor, num mercado que apresenta margens de comercialização relativamente baixas.

É em geral aceito que a formação de preços de várias commodities agrícolas ocorre nas bolsas de mercadorias e futuros internacionais e, através da dedução dos custos de transporte, portuários, armazenamento, impostos e outros, chega-se aos preços nas várias regiões de comercialização. No caso da soja, os preços futuros são formados na Chicago Board of Trade (CBOT). O efeito dos preços internacionais sobre os domésticos se dá também no Brasil, apesar de ser o segundo maior produtor e exportador mundial de soja, responsável por cerca de $20 \%$ da produção do grão, ficando atrás apenas dos EUA, como visto na Figura 1.

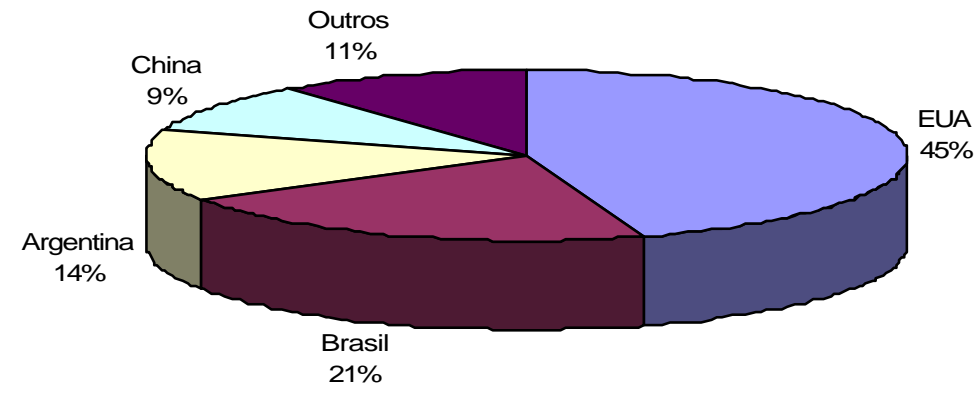

Figura 1 - Participação relativa dos principais países produtores na produção mundial de soja, safra 2000/2001.

Fonte: USDA (2001) 
Embora haja grande número de estudos relacionados à formação dos preços da soja no mercado interno, todos aqueles citados neste trabalho convergem para o fato de os preços domésticos serem função dos preços internacionais.

Segundo Mafioletti (2000), a formação dos preços no mercado interno acontece em dois níveis: i) preços recebidos pelos exportadores e ii) preços recebidos pelos produtores. No primeiro caso, segundo Aguiar (1990), os preços recebidos pelos exportadores brasileiros baseiam-se nas cotações da Bolsa de Chicago (CBOT), às quais são somados prêmios (positivos ou negativos) específicos para os produtos brasileiros. Barros et al (1997) afirmam que, no caso particular do preço da soja no Brasil, estudos econométricos têm mostrado que a formação do seu preço dá-se de fora para dentro.

Barros et al (1997) ainda mostram que os preços da soja se formariam em mercados internacionais e os produtores seriam bem informados e passariam a reivindicar internamente preços compatíveis com os praticados no mercado externo. Dessa forma, as forças de oferta e demanda dos principais países produtores e consumidores refletem-se nas cotações da Bolsa de Chicago (CBOT) e, conseqüentemente, nos preços de comercialização entre países exportadores (Tabela 1) e importadores (Tabela 2). Os preços dos produtos do complexo soja no Brasil seriam baseados nas cotações da Bolsa de Chicago, às quais se acrescenta um ágio ou deságio (prêmio), chegando-se aos preços nos portos brasileiros. Deste preço no porto seriam deduzidos custos portuários, fretes, etc., chegando-se ao preço na processadora. Deste preço, deduzindo-se os custos de frete, operacionais, entre outros, obtém-se o preço que, juntamente com a concorrência em cada região, se chega ao preço a ser pago ao produtor. 
Tabela 1. Exportação de soja em grão dos principais países exportadores, média das safras 96/97 a 00/01 e estimativa para a safra 2001/02, em mil toneladas.

\begin{tabular}{lrr}
\hline País & Média 5 anos & 2001/02* \\
\hline EUA & 24.696 & 27.760 \\
Brasil & 10.551 & 18.400 \\
Argentina & 3.709 & 8.200 \\
Paraguai & 2.306 & 2.520 \\
Canadá & 724 & 700 \\
Outros & 1.420 & 1.906 \\
Mundo & 43.648 & 59.486 \\
\hline
\end{tabular}

Fonte: USDA (2002)

* Estimativa de abril de 2002

Tabela 2. Importação de soja em grão dos principais países importadores, média das safras 96/97 a 00/01 e estimativa para a safra 2001/2002, em mil toneladas.

\begin{tabular}{lrr}
\hline País & Média & $2001 / 02 *$ \\
\hline União Européia & 16.638 & 20.721 \\
China & 6.473 & 12.000 \\
Japão & 4.893 & 4.950 \\
México & 3.263 & 4.550 \\
Taiwan & 2.423 & 2.400 \\
Outros & 9.100 & 18.518 \\
Mundo & 43.985 & 58.589 \\
\hline
\end{tabular}

Fonte: USDA (2002)

*Estimativa de abril de 2002

Assim, o preço ao produtor dependerá também da necessidade da processadora obter o produto, repor estoques, etc. Este mecanismo é ilustrado na Tabela 3. 
Tabela 3. Cálculo do preço de paridade de exportação da soja em grão para a região de Maringá, Paraná em 18 de março de 2002.

\begin{tabular}{ll}
\hline Descrição & Valor \\
\hline $\begin{array}{l}\text { 1. Cotação do contrato da bolsa de Chicago,com } \\
\text { vencimento em maio de 2002 }\end{array}$ & 460,50 centavos de dólar por Bushel \\
2. Prêmio ${ }^{1 /}$ & -7 centavos de dólar por Bushel \\
3. Subtotal (1+2) & 435,50 centavos de dólar por Bushel \\
4. Fator de conversão para tonelada ${ }^{2 /}$ & 0,3674541 \\
5. FOB porto (3 x 4) & $\mathrm{US} \$ 166,64 / \mathrm{t}$ \\
6. Taxa de câmbio & 2,3410 \\
8. FOB porto em real $(5 \times 2,3410)$ & $\mathrm{R} \$ 390,10 / \mathrm{t}$ \\
9. Despesas de exportação & \\
9.1 Comissão do corretor de físico (R $\$ / \mathrm{t})$ & $\mathrm{R} \$ 1,1705 / \mathrm{t}$ \\
9.2 Corretagem de câmbio $(0,1875 \%$ de 8$)$ & $\mathrm{R} \$ 0,73 / \mathrm{t}$ \\
9.3 Despesas portuárias $(\mathrm{R} \$ / \mathrm{t})$ & $\mathrm{R} \$ 14,046 / \mathrm{t}$ \\
10 Valor no porto & $\mathrm{R} \$ 373,17 / \mathrm{t}$ \\
11. Quebra de transporte $(0,25 \%$ de 8$)$ & $\mathrm{R} \$ 0,98$ \\
12. Frete para o porto & $\mathrm{R} \$ 40,00 / \mathrm{t}$ \\
13. Paridade Maringá & $\mathrm{R} \$ 333,17 / \mathrm{t}$ ou $\mathrm{R} \$ 19,99 / \mathrm{saca}$ \\
\hline
\end{tabular}

Fonte: Atualizado a partir de Barros et al. (1997)

1/ Prêmio para embarque entre 15/03 e 15/04 no porto de Paranaguá, Paraná.

2/ Fator de conversão de centavos de dólar por bushel (de 60 libras) para dólar por tonelada.

Barros et al (1997) afirmam que entre os meses de outubro e novembro, quando se dá a colheita norte-americana, o preço no Brasil tende a ficar igual ou acima da paridade de exportação, o que inviabiliza a exportação. A partir do momento em que a soja norteamericana entra no mercado internacional, período esse de entressafra brasileira, o volume de exportação nacional decresce drasticamente, e a formação do preço é dada pelo mercado interno. No entanto, nos últimos anos, tem-se observado que, apesar de os preços no mercado interno no período de entressafra brasileira estarem acima da paridade de exportação, eles ainda são influenciados pelas cotações da soja no mercado internacional, como concluiu Mafioletti (2000). 
É interessante notar a localização geográfica dos países exportadores, na América, e dos principais países importadores, principalmente na Europa e na Ásia. Um país importador tem algumas alternativas de compra da soja, principalmente dos EUA, do Brasil e da Argentina e, para cada um desses pontos, existe um prêmio de exportação específico, que é maior quanto maiores forem as vantagens relativas de cada ponto, incluindo a distância relativa. Assim, para um importador europeu, a menor distância para compra da soja brasileira em relação à argentina tende a fazer com que o prêmio na Argentina seja menor que no Brasil, ou seja, o preço recebido pelos exportadores na Argentina seja menor que no Brasil.

Conforme descrito por Aguiar (1990), o prêmio, aparentemente, depende da combinação de uma série de condições ou critérios, alguns tendendo a aumentá-lo e outros a diminuí-lo. Contudo, esse autor não apresenta dados que comprovem as proposições e importância de cada variável.

Segundo Aguiar (1990), os principais critérios são:

1) Condições locais de oferta e demanda

Nesse caso, se a exportação for feita numa época em que o País tenha grande quantidade a oferecer (logo após uma boa safra), a tendência será de se pagar um prêmio menor (e até mesmo negativo). Se a exportação for feita na entressafra brasileira ou num ano de baixa produção, o prêmio tenderá a ser maior.

\section{2) Diferenças de qualidade}

Para exemplificar este efeito pode-se citar o caso do Rio Grande do Sul. O farelo proveniente deste estado apresenta menor teor de proteína que os farelos produzidos com soja do Paraná, Estados do Sudeste e Estados do Centro-Oeste. Assim, há uma tendência de serem oferecidos prêmios menores pelo farelo sul-rio-grandense. Com 
relação a qualidade física da soja, há relatos de que os produtores de frango nas Filipinas, que evitam importar soja da Argentina em função da qualidade inferior a dos outros países exportadores.

\section{3) Eficiência do porto exportador}

Como as despesas de transporte marítimo normalmente correm por conta dos importadores, esses estarão dispostos a pagar prêmios maiores se o produto for colocado num porto mais eficiente, que possibilite uma menor despesa de transporte. Como exemplo da influência dos portos sobre o prêmio, tem-se a situação das exportações argentinas. Os portos daquele País não oferecem condições para que os navios saiam com carga total, o que faz com que esses cargueiros tenham de parar no Brasil para completar a carga. Devido a essa deficiência portuária, há tendência de se pagar prêmio menor pelo produto argentino.

4) Condições de pagamento

Esse fator afeta particularmente o mercado de óleo, já que entre os países importadores há um predomínio de países pobres. Por exemplo, como os Estados Unidos financiam as compras de seus produtos (a juros relativamente baixos), e o Brasil e a Argentina só vendem à vista, muitos importadores aceitam pagar prêmios mais altos pelo produto norte-americano para desfrutar das vantagens creditícias oferecidas por aquele país.

Aguiar (1990) afirma ainda que, além dessas condições, quaisquer outras que representem vantagens para o importador potencial tenderão a elevar o valor do prêmio, enquanto que aquelas que representem desvantagens tenderão a depreciar o prêmio. 
Embora estas variáveis sejam importantes na formação do prêmio, elas só podem explicar diferentes valores observados para o prêmio em diferentes regiões, isto é, variáveis como diferenças de qualidade, eficiência do porto exportador, condições de pagamento, etc, tendem a não se alterar em um período relativamente longo de tempo, e assim não são capazes de explicar variações diárias nos valores observados para o prêmio em um mesmo porto exportador.

De fato, a transparência na formação do preço da soja tem como obstáculo o prêmio, cujo mecanismo de formação não é claramente conhecido. Isto se deve ao fato de o prêmio ser negociado entre poucas empresas, em um mercado fortemente oligopolizado. Mafioletti (2000) afirma que grandes empresas controlam o comércio mundial do grão, a industrialização e o comércio dos derivados no mercado mundial, como Cargill (EUA), Archer Daniels Midland Company - ADM - (EUA), Coinbra Louis Dreyfus (França) e Ceval-Bunge (Argentina).

O estudo e determinação do mecanismo de formação do prêmio de exportação da soja representam um ponto fundamental para compreensão da diferença entre o preço internacional e o recebido pelo produtor. Estes diferenciais são de grande importância e compõem um ponto que deve ser avançado em pesquisas futuras. Produtores interessados em negociar a soja com base nas cotações da CBOT precisam conhecer os diferenciais entre os preços recebidos pelo produtor e as cotações internacionais, com o que teriam maior poder de negociação na venda antecipada da soja.

\subsection{Objetivos gerais}

Este estudo busca entender o mercado de prêmio de exportação da soja em grão, seu mecanismo de formação, padrão sazonal, bem como as principais variáveis responsáveis pelas oscilações diárias e mensais, bem como determinar qual ou quais contratos futuros da bolsa de Chicago e prêmios (preços FOB) estão mais relacionados com os preços internos. 


\subsection{Objetivos específicos}

Especificamente, pretende-se:

1) descrever detalhadamente o mecanismo de formação do prêmio de exportação da soja em grão para o porto de Paranaguá, Paraná, definindo o que é o prêmio, por quais agentes ele é negociado, como é feita a negociação e quais as variáveis que o influenciam.

2) determinar qual vencimento futuro da CBOT somado ao prêmio (preço FOB) tem a relação mais significativa com os preços no mercado interno (Maringá, Paraná), a partir do fato de os trabalhos anteriores não rejeitarem a hipótese de que o preço interno da soja é formado a partir do preço internacional e que a inserção da variável prêmio deva aumentar o grau de ajustamento desses modelos.

Apesar da possibilidade de deslocamento ou construção de novas unidades de esmagamento no Centro-Oeste ou outras regiões onde a produção da soja tem expandido, optou-se por Maringá, Paraná, como ponto de referência para comparação entre os preços internos e as séries FOB. Esta escolha merece algumas considerações.

Segundo a Associação Brasileira das Industrias de Óleos Vegetais ( $\mathrm{ABIOVE}^{3}$ ), conforme observado na Tabela 4, o Paraná é o estado com maior capacidade instalada de

processamento de oleaginosas, isto é, 31.500 toneladas ao dia, o que corresponde a 29,2\% da capacidade total brasileira. Cerca de $80 \%$ das suas unidades de esmagamento (indústria e das cooperativas) localizam-se no interior (ABIOVE, 1997), próximo às zonas de produção, sendo que $34,72 \%$ da capacidade estática de esmagamento total

\footnotetext{
${ }^{3}$ ABIOVE. Banco de dados. São Paulo, 1997 a 2001.
} 
estão na região Norte do Estado. Como foco nesta região, destaca-se Maringá, importante centro produtor, processador e ponto estratégico no transporte da soja. Os preços aí observados, tanto nos negócios entre empresas como aqueles envolvendo produtores, serão a referência para as comparações que serão feitas entre mercado interno e externo. Analisadas as séries para a base entre as cotações da CBOT e os preços pagos ao produtor em Maringá, haverá melhores subsídios para negociação na venda antecipada da soja e para formulações de contratos que tenham a base como objeto de negociação.

Tabela 4. Capacidade instalada de processamento de oleaginosas no Brasil em 2001.

\begin{tabular}{lrr}
\hline ESTADO & TONELADA/DIA & $2001 / 02$ \\
\hline Paraná & 31.500 & 29,2 \\
Rio Grande do Sul & 19.000 & 17,6 \\
São Paulo & 14.700 & 13,6 \\
Mato Grosso & 10.820 & 10,0 \\
Goiás & 8.660 & 8,0 \\
Mato Grosso do Sul & 7.330 & 6,8 \\
Minas Gerais & 5.750 & 5,3 \\
Bahia & 5.200 & 4,8 \\
Santa Catarina & 4.130 & 3,8 \\
Pernambuco & 400 & 0,4 \\
Piaú́ & 260 & 0,2 \\
Ceará & 200 & 0,2 \\
Brasil (total) & 107.950 & \\
\hline
\end{tabular}

Fonte: ABIOVE (2002) 


\section{DEFINIÇÃO E CARACTERIZAÇÃO DO PRÊMIO}

Para definição do prêmio e determinação do seu mecanismo de formação, foram identificados os principais agentes no mercado de prêmio de exportação de soja no porto de Paranaguá, isto é, importadores, exportadores e corretores.

Definidos os principais agentes, foram realizadas entrevistas, buscando-se subsídios para descrever detalhadamente o mecanismo de formação do prêmio, apresentar sua definição, a negociação e as variáveis que o influenciam. Este capítulo apresenta os resultados das entrevistas realizadas.

\subsection{Definição do prêmio}

O prêmio de exportação da soja brasileira é fator que deve ser somado à cotação de Chicago para se obter o preço recebido pelo exportador (FOB). Este valor pode ser positivo, representando um ágio, ou negativo, representando um deságio sobre as

cotações do produto na Bolsa de Chicago. É negociado entre importadores e exportadores de soja e representa um mecanismo para relacionar as cotações da CBOT e do mercado local. Conforme sugerido por alguns agentes desse mercado, as cotações nesta bolsa refletem, em grande medida, as condições de oferta e demanda dos EUA, principalmente no curto-prazo.

O prêmio é negociado praticamente durante o ano todo, independente do fato do Brasil estar no período de safra ou entressafra. Mesmo no período de safra dos EUA (e entressafra brasileira), esse país não é capaz de abastecer todos os países consumidores, sendo parte da demanda suprida pela produção brasileira. Note-se que mesmo nesse período negociam-se prêmios para a próxima safra brasileira. 
Vale notar que normalmente a negociação do prêmio está associada à fixação de contratos de exportação. Estes contratos são na maior parte de médio e longo prazos (Frame Contracts), isto é, determinados em meses ou até anos, estabelecendo apenas o volume a ser exportado.

As variáveis determinantes do prêmio podem ser divididas entre aquelas relacionadas à movimentação física da soja e aquelas relacionadas à disponibilidade de produto na origem, disponibilidade de produtos substitutos e valor relativo para o importador.

Uma hipótese básica a ser testada neste estudo é de que as variáveis responsáveis pela formação do prêmio são originárias de fatores externos e domésticos.

Fatores externos que alteram o prêmio:

1) Frete marítimo

Como o frete marítimo ocorre normalmente por conta do importador, valores de frete mais altos (pela elevação do preço do petróleo, por exemplo) reduzem o valor do prêmio para regiões mais distantes aos pontos consumidores.

2) País de destino

Os principais importadores mundiais de soja são a União Européia e países asiáticos. Estes países diferem no nível de renda. Assim, em períodos em que a soja é exportada para países de renda maior, onde o consumo de proteína de origem animal é maior, e há maior consumo de derivados de soja, principalmente farelo, espera-se que o prêmio pago por estes países também seja maior. Espera-se também que países onde há restrição ao consumo de soja geneticamente modificada estejam dispostos a pagar um prêmio maior pela soja não transgênica produzida no Brasil. 
3) Produção nos EUA e Argentina

Os Estados Unidos e a Argentina respondem por 59\% da produção mundial de soja. Em anos em que a produção nesses países é elevada, a oferta mundial de soja aumenta, gerando excedente do produto, reduzindo o prêmio pago na exportação da soja brasileira, em relação aos anos em que há redução da produção nesses dois países.

4) Época do ano

A disponibilidade de soja em um mesmo ano respeita os períodos de safra e entressafra dos países produtores (caráter sazonal da produção). Quando os EUA estão no período de entressafra, o Brasil e a Argentina estão no período de safra. Contudo, em agosto e setembro, a maior parte da soja produzida no Brasil e na Argentina já foi comercializada e a maior parte da soja produzida nos EUA ainda não foi colhida. Assim, espera-se que nesses meses o prêmio assuma valores mais elevados que no período de colheita nesses países.

Fatores domésticos que alteram o prêmio:

1) Excedente de soja no mercado interno

Se a exportação brasileira ocorrer em um período de baixa disponibilidade de produto no mercado interno, como período de entressafra ou em um ano de baixa produção, o prêmio exigido pelo exportador será maior.

2) Preços dos derivados

A maior parte da soja produzida é consumida m forma de derivados, óleo e farelo, oriundos do esmagamento da soja. Quando os preços dos derivados aumentam em relação ao grão, espera-se que maior parcela da produção doméstica seja esmagada e reduzida a parcela de grãos exportada. Neste caso há redução na quantidade disponível de soja para exportação e o prêmio deverá aumentar.

3) Qualidade 
O teor de proteína da soja produzida no Rio Grande do sul é menor que a produzida nos demais estados. A colheita brasileira não é simultânea para todos os estados, de forma que quando se inicia a colheita da soja do Rio Grande do Sul, esperase que os prêmios se reduzam.

\section{4) Câmbio}

A desvalorização do câmbio tende a favorecer a exportação por permitir ao produtor receber mais reais pelo mesmo produto. Assim, quando o preço da soja aumenta, há estímulo para ampliação da venda da soja por parte do produtor, o que pode resultar em maior disponibilidade do produto para embarque e possivelmente prêmios menores.

\section{5) Chuva}

A ocorrência de chuvas no porto gera atraso no carregamento de alguns navios, implicando em aumento no custo para o importador, em função da maior permanência do navio no porto. Segundo alguns traders, o custo estimado de cada dia de atraso excede US\$ 10.000 (em 2002). Parte da elevação do custo do importador tende a ser neutralizada pela redução no prêmio, que tende a cair pelo redirecionamento de navios para outros portos. Como exemplo, um período de dez dias de chuva em Paranaguá geraria atraso significativo no embarque, fazendo com que outros navios fossem desviados para o porto de Santos, elevando a diferença entre o prêmio de Santos e de Paranaguá. Um terceiro efeito, melhor compreendido após a leitura do item seguinte, corresponde à elevação do calado de pontos de estrangulamento no transporte de soja da Argentina, reduzindo a necessidade de completar com soja brasileira a carga dos navios que saem daquele país, reduzindo o prêmio nos portos do Sul do Brasil.

6) Necessidade de embarque

Os navios que partem da Argentina sem estar completamente carregados têm de completar a carga no Brasil. Contudo, ao se aproximarem do país, não estando os 
vendedores dispostos a realizar negócios nos preços vigentes, os compradores pagam prêmios mais elevados para adquirir o produto. Os portos argentinos estão localizados predominantemente no Rio Paraná, por onde os navios devem passar até o mar. Segundo informações obtidas através de entrevistas, o ponto de estrangulamento é o canal de Mitri, no rio Paraná, onde o calado não passa de 30 pés, impossibilitando o carregamento total de navios com mais de 45.000 toneladas.

Havendo disponibilidade de séries estatísticas, as variáveis acima, levantadas através de entrevistas junto aos agentes do mercado, bem como aquelas apresentadas por Aguiar (1990), serão testadas, buscando verificar quais delas são significativas na explicação do prêmio.

\subsection{Agentes que atuam no mercado de prêmio}

Todos os exportadores e importadores de soja e/ou derivados atuam no mercado de prêmio. Os principais agentes neste mercado são: 1) cooperativas exportadoras de grãos; 2) indústrias; 3) tradings; 4) corretoras de prêmio e; 5) empresas importadoras finais.

As tradings respondem por grande parte do volume exportado. Ao longo dos anos, algumas dessas empresas - Cargill, Ceval-Bunge, ADM (Archer Daniels Midland Company), entre outras - tornaram-se responsáveis também por parte do processamento e venda da soja nos países de destino.

Outra parte dos negócios de prêmio pode ser realizada diretamente entre as empresas exportadoras e as importadoras. Como exemplo, imagine-se o caso de uma cooperativa exportadora de grãos que negocia diretamente com uma fábrica de rações na Europa. Nesse caso, não há intermediação de corretores. Porém, estas empresas necessitam de uma estrutura especializada para a negociação. Dentro das empresas exportadoras, como grandes cooperativas, há um profissional especializado na comercialização de um determinado produto, tanto no mercado interno quanto no externo - o que inclui a negociação do prêmio, isto é, nessas empresas, há um 
profissional especializado na comercialização da soja em grão, outro para farelo e outro para óleo. Já nas corretoras, há uma especialização do corretor nos mercados distintos. Assim, há um profissional responsável pelo mercado interno e outro pelo mercado externo, incluindo o prêmio. Seja qual for o tipo de empresa, quanto maior sua participação no mercado, o nível de especialização dos profissionais tende a ser maior.

\subsection{Dimensões do prêmio}

A dimensão geográfica do prêmio é dada, entre outras coisas, pela distância relativa entre os diferentes locais de origem da soja. Como exemplo, tem-se o caso de um comprador em Roterdã, na Europa, que para comprar soja no Golfo do México tem de pagar um ágio sobre a cotação da CBOT de US\$ 3,00 por tonelada. Para adquirir o mesmo volume em Paranaguá, Paraná, o frete marítimo é US\$ 1,00/t maior. O prêmio em um porto brasileiro deve refletir a diferença do custo de transporte da soja dos EUA para a Europa e do Brasil para a Europa. Desta forma, o prêmio pago em Paranaguá deverá ser de US\$2,00/t, se o transporte for a única variável considerada.

Levando-se em conta a dimensão geográfica do prêmio, espera-se que sejam pagos prêmios menores (ou até deságios) para portos mais distantes do país de destino. Assim,

espera-se que o país importador da soja produzida no Brasil influencie o prêmio pago nos portos brasileiros.

Todas as variáveis que alteram o custo de transporte marítimo podem influenciar os prêmios. No caso de dois portos com mesma distância em relação ao comprador, o custo de transporte marítimo, pago pelo importador, tende a ser maior para aquele menos eficiente, o que tende a reduzir o prêmio pago naquele porto. Contudo, estas variáveis tendem a explicar de forma mais significativa as diferenças nos valores de prêmio em diferentes portos, mas não podem explicar de forma significativa as variações ao longo do tempo em um mesmo porto. 
A partir da definição de que o prêmio representa um mecanismo para relacionar as cotações da CBOT e o mercado local, parte das variações do prêmio corresponde a alterações em variáveis que determinam os preços no país de origem mas não alteram as cotações da CBOT. Como exemplo, em um mês de maior consumo de farelo de soja no mercado interno, causado, por exemplo, pelo maior alojamento de aves, os preços do produto no mercado interno tendem a se elevar. Contudo, o maior consumo do derivado no Brasil pode não alterar as cotações do farelo na CBOT, aumentando a rentabilidade das indústrias no esmagamento do grão e venda do derivado no mercado interno, reduzindo a quantidade disponível para exportação, aumentando o valor de prêmio.

A necessidade do importador também pode gerar alterações no prêmio. Imagine o caso de um navio que foi parcialmente carregado com soja originada na Argentina. O restante da carga deve ser completado com soja produzida no Brasil. Contudo, devido a uma indisponibilidade de venda dos produtores brasileiros, é provável que os prêmios subam, para que a carga se complete, evitando ficar com o navio atracado no porto por muito tempo.

\subsection{Períodos de negociação do prêmio}

Embora os prêmios sejam negociados durante $\mathrm{o}$ ano todo, sem que haja aparentemente um mês mais importante para a negociação do prêmio, a evolução das lavouras brasileiras condiciona o período de maior negociação. Como exemplo, antes do plantio da safra, que ocorre no Brasil entre setembro e dezembro, os negócios de prêmio ocorrem para os meses de embarque a partir de abril, quando é pequena a probabilidade de ainda não ter se iniciado a colheita, e conseqüentemente, não haver disponibilidade de produto no mercado interno. À medida que as lavouras vão se desenvolvendo e se define o período de colheita, são realizados negócios para embarque em março, quando aproximadamente 52\% da área plantada com soja no Brasil já deverão estar colhidos. As negociações de prêmio para embarque na próxima safra começam normalmente em junho, sendo março o primeiro mês de embarque. As negociações para embarque nesse mês são conhecidas como posições técnicas. Espera-se que neste mês o prêmio pago seja 
maior que os pagos nos meses seguintes, já que esta é a primeira soja vendida no mercado internacional, visto que os EUA estão na entressafra e a Argentina ainda não iniciou a colheita.

No caso específico do embarque em março, esse é o mês de embarque de maior risco para o importador pois em caso de atraso na colheita no Brasil (por excesso de chuva por exemplo), o exportador terá de elevar o preço de compra para obter parte da soja em estoque. Assim, quanto mais distante do período de embarque, maior o risco de a disponibilidade interna de produto ser pequena, aumentando o risco do exportador, que cobra um prêmio maior para correr este risco.

Existem diversos tipos de contratos, sendo os mais comuns aqueles em que o importador tem o direito de fixar o valor do prêmio no momento mais favorável, usualmente até dez dias antes do período de embarque. Da mesma forma, em outros contratos, o exportador é quem define o melhor momento para fixar o prêmio. Qualquer que seja o contrato, após ser determinado o volume a ser exportado e o período de embarque, tanto o importador quanto o exportador podem assumir posições nos mercados futuros (CBOT) para se protegerem contra oscilações nos preços.

Pelo lado do importador, o risco dele é que o preço suba e tenha que comprar a soja a um valor acima daquele observado no momento do fechamento do contrato de exportação. Para se proteger, o importador assume posição comprada na CBOT. Pelo lado exportador, são duas as alternativas. A primeira se refere ao exportador que não detém o produto. Seu risco está associado à possibilidade dos preços subirem até o período de embarque, o que resultaria em uma rentabilidade da operação de exportação menor que a esperada. Neste caso, o agente assume posição comprada na bolsa de Chicago, fixando o preço para o contrato mais próximo do mês de embarque. A segunda possibilidade refere-se ao caso do exportador que detém o produto. Nesse caso, o risco é a possibilidade de queda dos preços. Nesse caso, ele assume a posição vendida na CBOT. Contudo, nos contratos em que o importador tem o direito de fixar o prêmio no momento que lhe parecer mais conveniente, isto é, quando assumir o menor valor, o 
exportador fica vulnerável às oscilações no prêmio, o que também poderia alterar a rentabilidade da exportação. Para eliminar este risco, o exportador realiza uma operação de hedge perfeito do prêmio, utilizando o próprio mercado.

\subsection{Hedge perfeito do prêmio}

Imagine um exportador $\mathrm{A}$, que fechou em setembro um contrato de exportação de farelo com uma empresa importadora B, btalizando 5.000 toneladas, para embarque em maio do próximo ano. O contrato especifica que a empresa importadora tem o direito de fixar o prêmio no momento que julgar oportuno. Ambos assumem posições nos mercados futuros, comprando ou vendendo contratos futuros com vencimento em maio, protegendo-se contra oscilações de preços. Contudo, o exportador ainda corre o risco do importador fixar o prêmio em um momento que o valor deste tenha caído.

Para eliminar esse risco, o exportador verifica que há, ainda em fevereiro, importadores desejando negociar o prêmio a -11 dólares por tonelada curta sobre a cotação do dia para o contrato da CBOT com vencimento em maio. O exportador vende, então, 5000 t de farelo para embarque em maio no valor de prêmio de -11 dólares por tonelada curta sobre o contrato de maio da CBOT para a empresa importadora C.

Em 15 de abril o mercado de prêmio para maio está em -16 e a empresa importadora B decide fixar seu valor em -16 . Contudo, se há possibilidade de fixar o prêmio em -16, há também algum exportador desejando negociar o prêmio a esse valor. Neste momento, a empresa exportadora A compra $5000 \mathrm{t}$ de farelo com prêmio de -16 de uma empresa exportadora D.

Em maio, mês de embarque, a empresa exportadora A entrega $5000 \mathrm{t}$ de farelo para a empresa importadora B com prêmio de -16 , redirecionando as $5000 \mathrm{t}$ da empresa exportadora D para a empresa importadora $C$, ganhando na transação +5 , o que somado aos -16 da operação original resulta nos -11 esperados, fixando o valor do prêmio do exportador $\mathrm{A}$, independente do momento que o importador $\mathrm{B}$ venha a fixar o prêmio na 
operação original. Nota-se que nesta operação o resultado final do hedge é sempre igual ao esperado (base igual a zero), implicando na ausência de risco de base, o que segundo Hull (1996), caracteriza esta operação como um hedge perfeito, apesar de se tratar de operação a termo e não mercado futuro.

\subsection{Prêmio em outros portos brasileiros}

Em todo porto onde há exportação de soja, há necessariamente negociação de prêmio, mesmo que este seja igual a zero. Contudo, para os portos ao norte de Paranaguá (Santos, Vitória, etc.), são negociados apenas diferenças (spreads) sobre o prêmio de Paranaguá. Como exemplo, uma indústria localizada no Mato Grosso fecha em setembro um contrato de exportação de 20.000 toneladas de soja para embarque no porto de Santos em Março do ano seguinte. Neste caso, não é negociado o prêmio para o mês de embarque mas apenas a diferença sobre o prêmio de Paranaguá.

\subsection{Operações de Flat Price}

Em alguns casos, quando os agentes não querem se preocupar com a negociação do prêmio e com a evolução das cotações na CBOT, eles optam por operações de flat price. Estas operações consistem simplesmente na fixação tanto dos preços como do prêmio no fechamento do contrato de exportação, fixando assim o preço FOB que será utilizado na exportação. No Brasil, as operações de flat price correspondem a uma pequena parcela dos negócios realizados na exportação.

\subsection{Mecanismo de formação do prêmio}

O prêmio é um valor negociado em um mercado específico, determinado através de negociação entre importadores e exportadores. Importadores são todos aqueles agentes interessados na importação tanto da soja em grão como na forma de derivados (por exemplo esmagadoras e indústrias de ração) e empresas que atuam comprando soja no país de origem e vendendo no país de destino (tradings). Esses agentes estão 
interessados em fechar contratos com o menor valor possível do prêmio. Por outro lado, exportadores são todos aqueles agentes interessados na venda externa tanto da soja em grão como na forma de derivados. Esse agente está interessado em fechar contratos com o maior valor possível do prêmio. No entanto, como o prêmio é um valor determinado no mercado, nem sempre ele será igual ao desejado pelos dois agentes. O valor desejado tanto pelo exportador quanto pelo importador segue uma lógica econômica, descrita a seguir.

\subsubsection{Determinação do valor do prêmio pela ótica do exportador}

Estes agentes definem o patamar mínimo aceitável do prêmio em função da rentabilidade de cada possível combinação de uso da soja. As alternativas para comercialização da soja são:

1) Vender a soja em grão no mercado externo

2) Esmagar a soja e vender o óleo e o farelo no mercado interno

3) Esmagar a soja e vender o óleo e o farelo no mercado interno

4) Esmagar a soja e vender o óleo no mercado interno e o farelo no mercado externo

5) Esmagar a soja e vender o óleo no mercado externo e o farelo no mercado interno

Durante todo o ano o vendedor trabalha com esta planilha, determinando a rentabilidade de cada operação, conforme ilustrado na Tabela 5. 
Tabela 5. Cálculo da rentabilidade das operações de exportação de soja em grão e do esmagamento e exportação de óleo e farelo de soja para uma indústria localizada em Cascavel, Paraná, na segunda quinzena de outubro de 2001.

\begin{tabular}{|c|c|c|c|}
\hline DESCRIÇÃO & Soja Grão & Farelo & Óleo \\
\hline Mercado & Externo & Externo & Externo \\
\hline 1. Cotação da soja na bolsa de Chicago (A) & 426,75 & 160,00 & 15,80 \\
\hline 2. Prêmio (A) & 26,00 & 8,00 & 0,80 \\
\hline 3. Preço CIF Paranaguá (US\$/t) (B) & 166,35 & 185,19 & 365,96 \\
\hline 4. Taxa de câmbio (R\$/US\$) & 2,4100 & 2,4100 & 2,4100 \\
\hline 5. Receita bruta $(\mathrm{R} \$ / \mathrm{t})$ & 400,91 & 446,30 & $881,97,07$ \\
\hline 6. Despesas $(\mathrm{R} \$ / \mathrm{t})$ & 32,29 & 32,42 & 43,57 \\
\hline a. Frete ao porto & 24,00 & 24,00 & 26,00 \\
\hline b. Despesas portuárias (D) & 14,46 & 14,46 & 21,69 \\
\hline c. Taxas e comissões $(\mathrm{E})$ & 1,21 & 1,21 & 2,41 \\
\hline d. Corretagem de câmbio $(\mathrm{F})$ & 0,75 & 0,84 & 1,65 \\
\hline 7. Preço equivalente em Cascavel $(\mathrm{R} \$ / \mathrm{t})$ & 360,50 & 405,80 & 830,21 \\
\hline 8. Preço derivados em equivalente soja $(\mathrm{R} \$ / \mathrm{t})(\mathrm{C})$ & & \multicolumn{2}{|c|}{459,87} \\
\hline 9. Custo de esmagamento $(\mathrm{R} \$ / \mathrm{t})$ & & \multicolumn{2}{|c|}{28,92} \\
\hline 10. Preço da soja em Cascavel (R $\$ / t)$ & 408,33 & \multicolumn{2}{|c|}{408,33} \\
\hline 11. Receita líquida $(\mathrm{R} \$ / \mathrm{t})$ & $-47,83$ & \multicolumn{2}{|c|}{22,62} \\
\hline
\end{tabular}

Fonte: Canziani \& Guimarães (2002)

(A) Centavos de dólar por bushel para o grão, dólar por tonelada curta para o farelo e centavos de dólar por libra-peso para o óleo

(B) 1 bushel de soja $=27,216 \mathrm{~kg} ; 1$ tonelada curta $=0,9072$ toneladas métricas; 1 librapeso $=0,4536 \mathrm{Kg}$

(C) Rendimento da soja em farelo: 76,5\%; rendimento em óleo: $18 \%$

(D) US\$ 6,00/tonelada para o grão e farelo e US\$ 9,00/tonelada para o óleo

(E) US\$ 0,50/tonelada para o grão e farelo e US\$1,00/tonelada para o óleo

(F) $0,1875 \%$ sobre o item 5 
Tabela 6. Cálculo da rentabilidade das operações de esmagamento e venda no mercado interno do óleo e farelo de soja para uma indústria localizada em Cascavel, Paraná, na primeira quinzena de outubro de 2001.

\begin{tabular}{lcc}
\hline $\begin{array}{l}\text { DESCRIÇÃO } \\
\text { Mercado }\end{array}$ & $\begin{array}{c}\text { Farelo } \\
\text { Interno }\end{array}$ & $\begin{array}{c}\text { Óleo } \\
\text { Interno }\end{array}$ \\
\hline 1. Preço (A) & 420,00 & 870,00 \\
2. ICMS & & 104,40 \\
3. Preço s/ ICMS & 420,00 & 765,60 \\
4. Frete $(\mathrm{R} \$ / \mathrm{t})$ & 27,00 & 75,00 \\
5. Receita bruta em Cascavel $(\mathrm{R} \$ / \mathrm{t})$ & 393,00 & 690,60 \\
4. Preço em equivalente soja $(\mathrm{R} \$ / \mathrm{t})$ & \multicolumn{2}{c}{424,95} \\
5. Preço soja Cascavel $(\mathrm{R} \$ / \mathrm{t})$ & \multicolumn{2}{c}{366,67} \\
7. Custo industrialização $(\mathrm{R} \$ / \mathrm{t})$ & \multicolumn{2}{c}{22,00} \\
8. Receita líquida $(\mathrm{R} \$ / \mathrm{t})$ & \multicolumn{2}{c}{36,29} \\
\hline
\end{tabular}

Fonte: Canziani \& Guimarães (2002)

(A) Preço FOB para o farelo e CIF São Paulo com 12\% ICMS para o óleo

No exemplo mostrado nas tabelas 5 e 6 , as alternativas da indústria foram limitadas a três, isto é, a empresa pode exportar a soja na forma de grão, esmagar o grão e exportar o óleo e o farelo ou esmagar o grão e vender o óleo e o farelo no mercado interno. Não foram consideradas as demais alternativas que a empresa disporia, ou seja, esmagar a soja internamente vendendo o farelo no mercado externo e o óleo no mercado interno ou vender o farelo no mercado interno e o óleo no mercado externo. A rentabilidade das operações de venda de óleo e farelo, qualquer que seja a combinação, deve sempre ser tomada em conjunto, já que não é possível obter o farelo sem também produzir o óleo e vice-versa.

Neste caso, percebe-se claramente que a melhor estratégia para essa empresa é esmagar a soja e vender os derivados - óleo e o farelo - no mercado interno, já que esta é a alternativa mais rentável dentre as colocadas nas tabelas 5 e 6 .

No exemplo mostrado, o valor mínimo do prêmio para a exportação da soja em grão seria US\$ 1,22 por bushel. Se este valor do prêmio for inserido na Tabela 6, a rentabilidade da exportação do grão seria igual a $\mathrm{R} \$ 37,02 / \mathrm{t}$, semelhante à rentabilidade 
da melhor alternativa, isto é, esmagar a soja e vender os derivados no mercado interno ( $\mathrm{R} \$ 36,29 / \mathrm{t})$. De fato dados mostram que o volume exportado diminui significativamente no período de entressafra brasileiro e os prêmios pagos na exportação atingem os maiores valores do ano.

As tabelas 7 e 8 mostram os mesmos cálculos realizados em abril de 2001, período de safra no mercado interno. Neste caso, a melhor alternativa deixa de ser a venda do óleo e farelo no mercado interno, sendo que o esmagamento da soja e a exportação do óleo e farelo passam a ser a alternativa mais rentável dentre as colocadas. Nestas condições, o prêmio mínimo aceitável na exportação do grão é de 10 centavos de dólar por bushel. Se esse valor for inserido na Tabela 7, a exportação do grão resultaria em um rentabilidade de $\mathrm{R} \$ 34,08 / \mathrm{t}$, semelhante à rentabilidade obtida na exportação dos derivados. 
Tabela 7. Cálculo da rentabilidade das operações de esmagamento e venda no mercado interno do óleo e farelo de soja para uma indústria localizada em Cascavel, Paraná, em abril de 2001.

\begin{tabular}{|c|c|c|c|}
\hline DESCRIÇÃO & Soja Grão & Farelo & Óleo \\
\hline Mercado & Externo & Externo & Externo \\
\hline 1. Chicago (A) & 435,75 & 153,30 & 15,49 \\
\hline 2. Prêmio (A) & $-3,00$ & $-7,50$ & $-2,30$ \\
\hline 3. Preço CIF Paranaguá (US\$/tonelada) (B) & 159,01 & 160,72 & 290,78 \\
\hline 4. Taxa de câmbio (R\$/US\$) & 2,1622 & 2,1622 & 2,1622 \\
\hline 5. Receita bruta $(\mathrm{R} \$ / \mathrm{t})$ & 343,80 & 347,50 & 628,73 \\
\hline 6. Despesas $(\mathrm{R} \$ / \mathrm{t})$ & 46,70 & 46,71 & 56,80 \\
\hline a. Frete ao porto (ferroviário) & 32,00 & 32,00 & 34,00 \\
\hline b. Despesas portuárias (D) & 12,97 & 12,97 & 19,46 \\
\hline c. Taxas e comissões (E) & 1,08 & 1,08 & 2,16 \\
\hline d. Corretagem de câmbio $(\mathrm{F})$ & 0,64 & 0,65 & 1,18 \\
\hline 7. Preço equivalente em Cascavel $(\mathrm{R} \$ / \mathrm{t})$ & 297,10 & 300,79 & 571,93 \\
\hline 8. Preço derivados em equivalente soja $(\mathrm{R} \$ / \mathrm{t})(\mathrm{C})$ & & \multicolumn{2}{|c|}{333,05} \\
\hline 9. Custo de esmagamento (R $\$ / \mathrm{t})$ & & \multicolumn{2}{|c|}{25,95} \\
\hline 10. Preço da soja em Cascavel $(\mathrm{R} \$ / \mathrm{t})$ & 273,33 & \multicolumn{2}{|c|}{273,33} \\
\hline 11. Receita líquida $(\mathrm{R} \$ / \mathrm{t})$ & 23,77 & \multicolumn{2}{|c|}{33,77} \\
\hline
\end{tabular}

Fonte: Canziani \& Guimarães (2002)

(A) Centavos de dólar por bushel para o grão, dólar por tonelada curta para o farelo e centavos de dólar por libra-peso para o óleo

(B) 1 bushel de soja $=27,216 \mathrm{~kg} ; 1$ tonelada curta $=0,9072$ toneladas métricas; 1 librapeso $=0,4536 \mathrm{Kg}$

(C) Rendimento da soja em farelo: $76,5 \%$; rendimento em óleo: $18 \%$

(D) US\$ 6,00/tonelada para o grão e farelo e US\$ 9,00/tonelada para o óleo

(E) US\$ 0,50/tonelada para o grão e farelo e US\$ 1,00/tonelada para o óleo

(F) $0,1875 \%$ sobre o item 5 
Tabela 8. Cálculo da rentabilidade das operações de esmagamento e venda no mercado interno do óleo e farelo de soja para uma indústria localizada em Cascavel, Paraná, em abril de 2001.

\begin{tabular}{|c|c|c|}
\hline $\begin{array}{l}\text { DESCRIÇÃO } \\
\text { Mercado }\end{array}$ & $\begin{array}{l}\text { Farelo } \\
\text { Interno }\end{array}$ & $\begin{array}{c}\text { Óleo } \\
\text { Interno }\end{array}$ \\
\hline 1. Preço (A) & 328,05 & 708,34 \\
\hline 2. ICMS & & 85,00 \\
\hline 3. Preço s/ ICMS & 328,05 & 623,34 \\
\hline 4. Frete $(\mathrm{R} \$ / \mathrm{t})$ & 25,60 & 64,00 \\
\hline 5. Receita bruta em Cascavel $(\mathrm{R} \$ / \mathrm{t})$ & 302,45 & 559,34 \\
\hline 4. Preço em equivalente soja ( $R \$ / t)$ & \multicolumn{2}{|c|}{332,06} \\
\hline 5. Preço soja Cascavel $(\mathrm{R} \$ / \mathrm{t})$ & \multicolumn{2}{|c|}{273,33} \\
\hline 7. Custo industrialização $(R \$ / t)$ & \multicolumn{2}{|c|}{25,95} \\
\hline 8. Receita líquida $(\mathrm{R} \$ / \mathrm{t})$ & \multicolumn{2}{|c|}{32,78} \\
\hline
\end{tabular}

Fonte: Canziani \& Guimarães (2002)

(A) Preço FOB para o farelo e CIF São Paulo com 12\% de ICMS para o óleo

Este raciocínio acompanha o comportamento sazonal do prêmio sugerido pelos agentes do mercado, que tende a diminuir no período de safra e aumentar no período de entressafra.

Estes exemplos deixam evidente a importância dos preços dos derivados tanto no mercado interno quanto no mercado externo, determinados basicamente pelo excedente de produto tanto internamente quanto externamente. Assim, variáveis que aumentem a demanda de derivados no mercado interno ou reduzam sua oferta poderiam elevar o preço dos derivados neste mercado, elevando o prêmio mínimo na exportação da soja e vice-versa. Da mesma forma, variáveis que aumentem a demanda por derivados ou reduzam sua oferta no mercado internacional endem a elevar o valor do prêmio, sendo o oposto também verdadeiro. De maneira geral, do ponto de vista do exportador, qualquer variável que altere a rentabilidade de qualquer uma das alternativas de comercialização tende a alterar os prêmios exigidos pelo exportador. 


\subsubsection{Determinação do valor do prêmio pela ótica do importador}

Do ponto de vista do importador, o prêmio representa um mecanismo de equalização do custo de aquisição das diferentes fontes de proteína vegetal, que serão utilizadas na elaboração de rações animais e de óleos vegetais.

O ponto central no cálculo do prêmio máximo a ser pago pelo importador é determinado pelo custo de se trazer o mesmo montante de proteína vegetal até o local de consumo, isto é, na indústria esmagadora, no caso da importação de grãos, ou nas indústrias de ração, no caso da importação de farelo, ambos localizados no país de destino, ou ainda na refinadora de óleo.

Vale notar que as alternativas não incluem apenas a importação de soja em grão ou derivados, mas também a possibilidade de importação de produtos substitutos, utilizados no destino final, tanto na elaboração de rações, como de produtos destinados ao consumo final, como o óleo refinado, margarinas, etc, respeitando as possibilidades técnicas de substituição. No caso do farelo, os custos não são comparados através de preços absolutos, mas sim em termos relativos, através do equivalente em teor protéico de cada substituto. Desta forma, a planilha de cálculo do custo do produto, colocado no mercado consumidor final, depende do produto a ser comprado e da origem. As tabelas 9, 10 e 11 mostram as principais fontes de oleaginosas, farelos protéicos, óleos vegetais e os principais países produtores, consumidores, exportadores e importadores. As figuras 2, 3 e 4 mostram a grande dependência da soja em grão e do farelo, como fonte de proteína, e a menor dependência do óleo de soja no consumo total de óleos vegetais. 
Tabela 9. Principais países produtores, consumidores, exportadores e importadores de oleaginosas, média das safras 2000/01 e 2001/02, valores em mil toneladas.

\begin{tabular}{|c|c|c|c|c|c|c|c|c|c|c|}
\hline Produto & Produção & $\%$ & Produtor & $\%$ & Consumidor & $\%$ & Exportador & $\%$ & Importador & $\%$ \\
\hline Soja & 178782,5 & 57,2 & EUA & 43,0 & EUA & 27,9 & EUA & 47,8 & UE & 33,9 \\
\hline Colza & 36986,0 & 11,8 & China & 31,2 & China & 34,3 & Canadá & 42,1 & UE & 35,0 \\
\hline Algodão & 32950,0 & 10,5 & China & 22,4 & China & 22,4 & Austrália & 36,0 & EUA & 24,5 \\
\hline Amendoim & 29548,5 & 9,5 & China & 43,4 & China & 41,9 & China & 26,4 & UE & 37,7 \\
\hline $\begin{array}{l}\text { Girassol } \\
\text { Palma }\end{array}$ & 22187,5 & 7,1 & Rússia & 14,9 & UE & 21,2 & Ucrânia & 22,5 & UE & 75,2 \\
\hline Kernel & 6416,5 & 2,1 & Malásia & 50,5 & Malásia & 50,6 & Papua N. G. & 36,5 & Indonésia & 75,3 \\
\hline Copra & 5515,0 & 1,8 & Filipinas & 44,0 & Filipinas & 43,3 & Papua N. G. & 25,9 & UE & 41,0 \\
\hline
\end{tabular}

Fonte: USDA (2002)

Tabela 10. Principais países produtores, consumidores, exportadores e importadores de farelos e farinhas protéicos. Valores em mil toneladas.

\begin{tabular}{lrlllllllll}
\hline \multicolumn{1}{c}{ Produto } & Produção & $\%$ & Produtor & $\%$ & Consumidor & $\%$ & Exportador & $\%$ & Importador & $\%$ \\
\hline Soja & 122219,0 & 67,9 & EUA & 29,5 & EUA & 23,9 & Argentina & 35,2 & UE & 49,0 \\
Colza & 21109,5 & 11,7 & China & 35,3 & China & 32,6 & EU & 43,5 & UE & 56,8 \\
Algodão & 11305,5 & 6,3 & China & 23,4 & China & 22,2 & China & 24,4 & Corea do Sul 34,1 \\
Girassol & 8984,5 & 5,0 & UE & 25,0 & UE & 38,3 & Argentina & 51,3 & UE & 73,2 \\
Peixe & 5992,5 & 3,3 & Peru & 28,5 & China & 23,6 & Peru & 46,1 & UE & 29,4 \\
Amendoim & 5358,0 & 3,0 & China & 47,4 & China & 47,8 & Senegal & 35,2 & UE & 70,6 \\
Palma & 3355,0 & 1,9 & Malásia & 52,5 & UE & 69,7 & Malásia & 54,3 & UE & 88,7 \\
Kernel & & & & & & & & & & \\
Copra & 1769,5 & 1,0 & Filipinas & 42,8 & UE & 26,9 & Filipinas & 15,3 & UE & 12,7 \\
\hline
\end{tabular}

Fonte: USDA (2002)

Tabela 11. Principais países produtores, consumidores, exportadores e importadores de óleos vegetais, média das safras 2000/01 e 2001/02, valores em mil toneladas.

\begin{tabular}{lrlllllllll}
\hline \multicolumn{1}{c}{ Produto } & Produção & $\%$ & Produtor & $\%$ & Consumidor & $\%$ & Exportador & $\%$ & Importador & $\%$ \\
\hline Soja & 27838,0 & 31,4 & EUA & 30,3 & EUA & 27,1 & Argentina & 40,9 & Índia & 16,5 \\
Palma & 21866,5 & 24,7 & Malásia & 50,7 & índia & 16,9 & Malásia & 59,9 & Índia & 22,4 \\
Colza & 13349,5 & 15,1 & China & 30,8 & China & 31,6 & EU & 61,1 & UE & 46,7 \\
Girassol & 8932,5 & 10,1 & UE & 23,4 & UE & 22,5 & Argentina & 37,7 & UE & 22,7 \\
Amendoim & 4210,0 & 4,8 & China & 48 & China & 48,9 & Senegal & 31,9 & UE & 76,6 \\
Algodão & 3537,0 & 4,0 & China & 24,5 & China & 24,2 & EUA & 33,7 & Índia & 19,5 \\
Coco & 3431,0 & 3,9 & Filipinas & 44,9 & UE & 26,5 & Filipinas & 63,1 & UE & 50,3 \\
Palma & 2968,5 & 3,4 & Malásia & 51 & Malásia & 31,1 & Malásia & 46,2 & UE & 57,1 \\
Kernel & 2435,5 & 2,7 & UE & 79,8 & UE & 72,2 & UE & 86,8 & UE & 67,8 \\
Oliva & & & & & & & & & &
\end{tabular}

Fonte: USDA (2002) 


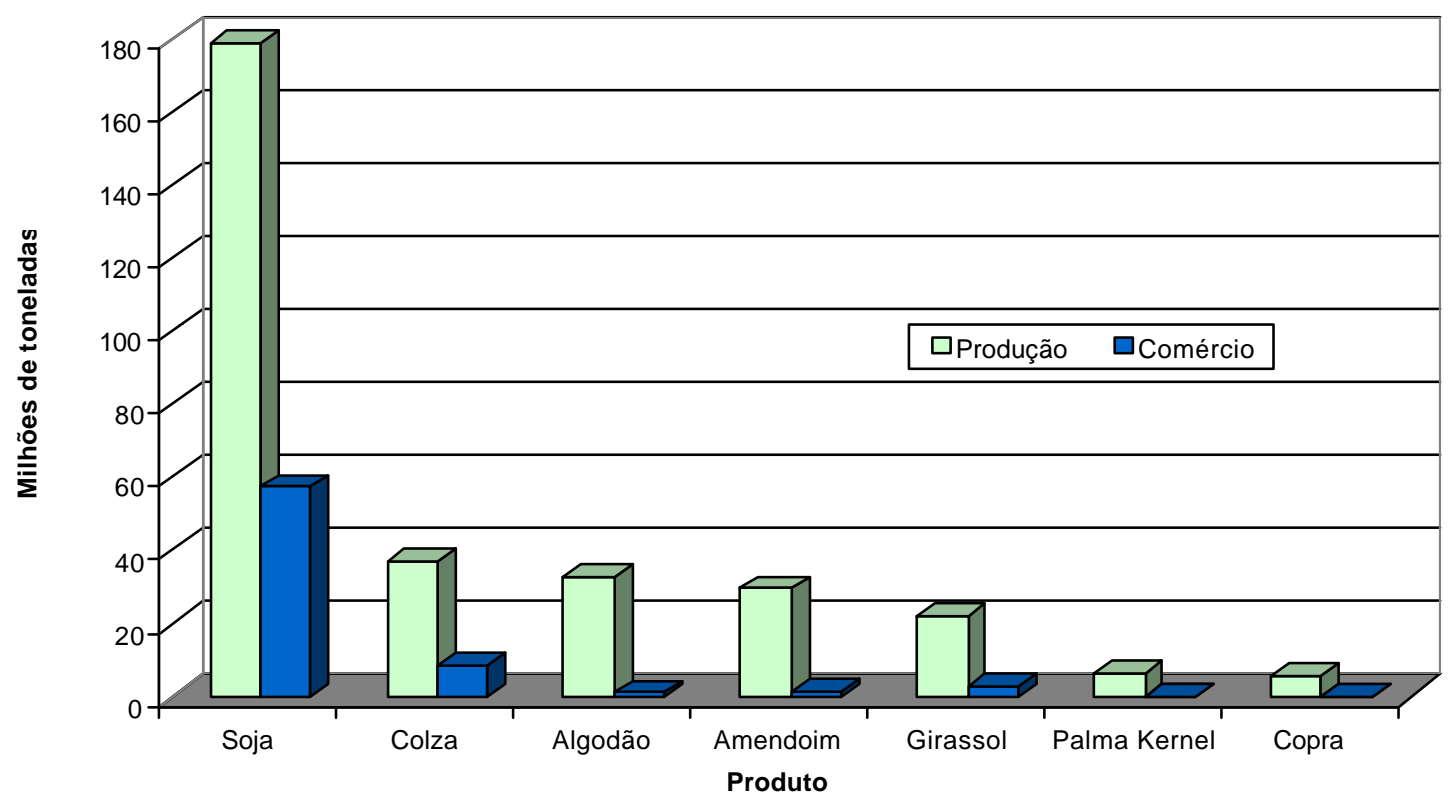

Figura 2 - Produção e comércio mundial de oleaginosas. Média das safras 2000/01 e 2001/02. Valores em mil toneladas.

Fonte: USDA (2002)

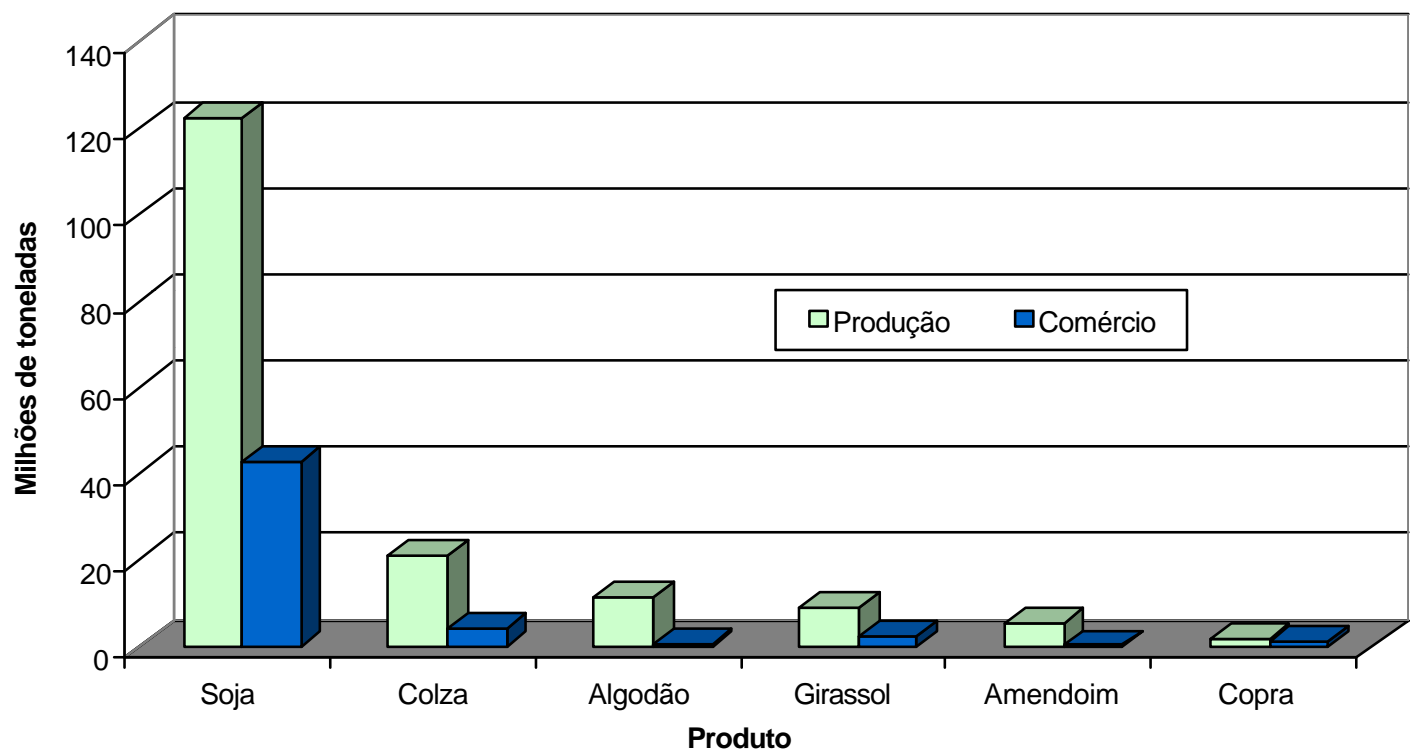

Figura 3 - Produção e comércio mundial de farelos vegetais. Média das safras 2000/01 e 2001/02. Valores em mil toneladas.

Fonte: USDA (2002) 


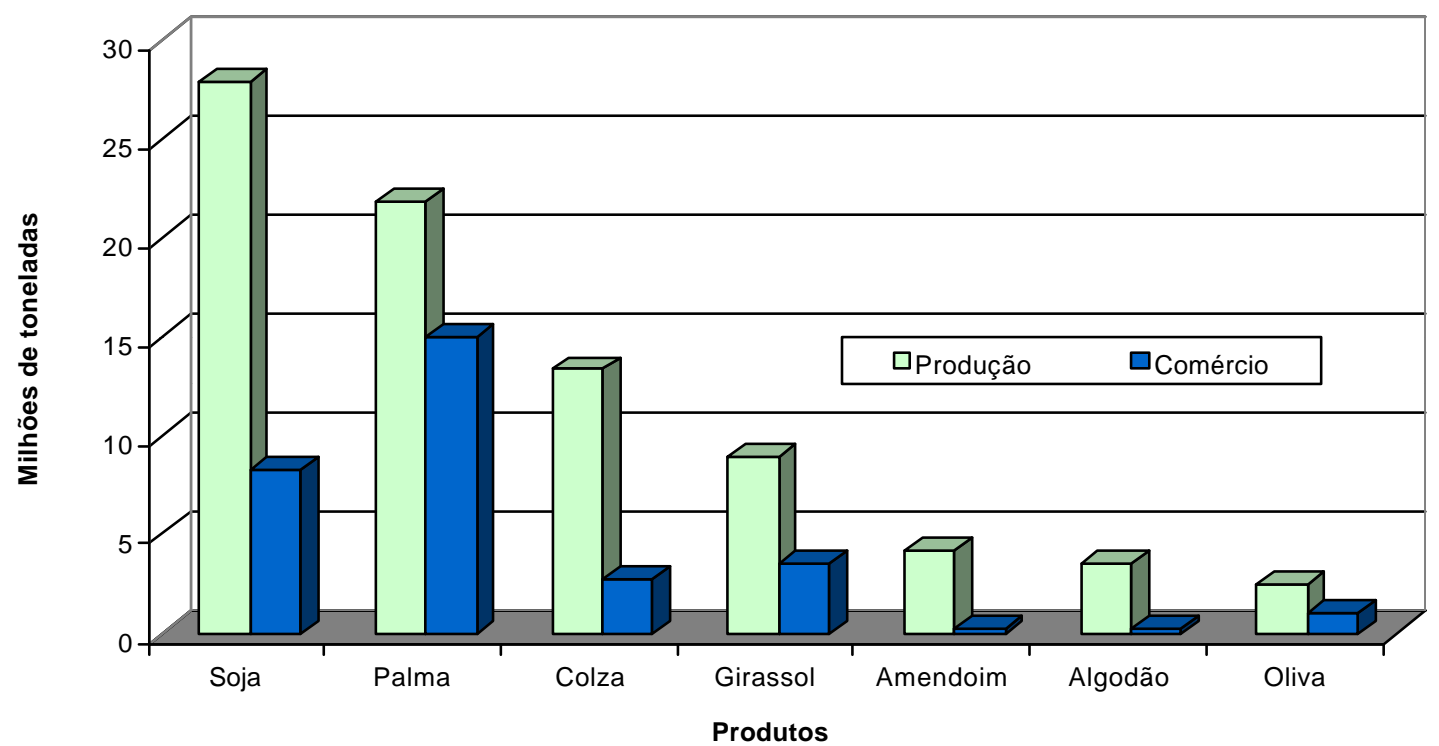

Figura 4 - Produção e comércio mundial de óleos vegetais. Média das safras 2000/01 e 2001/02. Valores em mil toneladas.

Fonte: USDA (2002)

As tabelas 12, 13 e 14 apresentam o cálculo do valor do prêmio para a soja em grão na ótica do importador, elaboradas a partir de entrevistas com agentes do mercado, tendo como fonte de abastecimento o Brasil, através do porto de Paranaguá, os Estados Unidos, através do Golfo do México, e a Argentina, através do porto de Buenos Aires. Nota-se que no exemplo não foi inserida a possibilidade de compra de produtos substitutos e nem de outras fontes de abastecimento além das citadas. 
Tabela 12. Cálculo do valor do prêmio da soja em grão para um importador em Roterdã, abastecendo-se no porto de Paranaguá, Paraná, na segunda quinzena de Março de 2002.

\begin{tabular}{|c|c|}
\hline DESCRIÇÃO & VALOR \\
\hline $\begin{array}{l}\text { 1) Preço dos derivados na indústria esmagadora em Roterdã, em equivalente soja em } \\
\text { US\$/t (a) }\end{array}$ & 185,0 \\
\hline 2) Custo de transporte da soja do porto de Roterdã até a industria em US\$/t & 10,0 \\
\hline 3) Preço do produto no Porto, em US\$/t (1 - 2) & 175,0 \\
\hline 4) Custo de desembarque no porto, em US\$/t & 4,00 \\
\hline 5) Preço do produto no navio, em US\$/t (3 - 4) & 171,0 \\
\hline 6) Seguro da Carga (FOG) em US\$/t (b) & 3,0 \\
\hline 7) Frete Marítimo em US\$/t & 13,0 \\
\hline 8) Preço FOB em Paranaguá em US\$/t (5 - 6 - 7) & 155,0 \\
\hline 9) Preço FOB Paranaguá em US\$/bushel $(8 * 0,0272154)$ & 4,2184 \\
\hline 10) Chicago US\$/bushel (c) & 4,5750 \\
\hline 11) Prêmio em Paranaguá (US\$/bushel) (9-10) & $-0,36$ \\
\hline
\end{tabular}

Fonte: Dados da pesquisa

(a) Rendimento da soja em farelo: $78 \%$; rendimento em óleo: $20 \%$

(b) FOG (For Our Guidance)

(c) Sobre o primeiro vencimento da CBOT

Tabela 13. Cálculo do valor do prêmio da soja em grão para um importador em Roterdã, abastecendo-se no Golfo do México, EUA, na segunda quinzena de Março de 2002.

\begin{tabular}{|c|c|}
\hline DESCRIÇÃO & VALOR \\
\hline $\begin{array}{l}\text { 1) Preço dos derivados na indústria esmagadora em Roterdã, em equivalente soja em } \\
\text { US\$/t (a) }\end{array}$ & 185,0 \\
\hline 2) Custo de transporte da soja do porto de Roterdã até a industria em US\$/t & 10,0 \\
\hline 3) Preço do produto no Porto, em US $\$ / t(1-2)$ & 175,0 \\
\hline 4) Custo de desembarque no porto, em US\$/t & 4,00 \\
\hline 5) Preço do produto no navio, em US\$/t (3 - 4) & 171,0 \\
\hline 6) Seguro da Carga (FOG) em US\$/t (b) & 3,0 \\
\hline 7) Frete Marítimo em US\$/t & 9,0 \\
\hline 8) Preço FOB no Golfo do México em US\$/t (5 - 6- 7) & 159,0 \\
\hline 9) Preço FOB no Golfo do México em US\$/bushel $(8 * 0,0272154)$ & 4,3273 \\
\hline 10) Chicago (US\$/bushel) (c) & 4,5750 \\
\hline 11) Prêmio no Golfo do México (US\$/bushel) (9-10) & $-0,25$ \\
\hline
\end{tabular}

Fonte: Dados da pesquisa

(a) Rendimento da soja em farelo: $78 \%$; rendimento em óleo: $20 \%$

(b) FOG (For Our Guidance)

(c) Sobre o primeiro vencimento da CBOT 
Tabela 14. Cálculo do valor do prêmio da soja em grão para um importador em Roterdã, abastecendo-se no porto de Buenos Aires, Argentina, na segunda quinzena de Março de 2002.

DESCRIÇÃO

1) Preço dos derivados na indústria esmagadora em roterdã, em equivalente soja em US\$/t (a)

2) Custo de transporte da soja do porto de Roterdã até a industria em US\$/t

3) Preço do produto no Porto, em US\$/t $(1-2)$

4) Custo de desembarque no porto, em US $\$ / t$

5) Preço do produto no navio, em US\$/t (3 - 4)

6) Seguro da Carga (FOG) em US\$/t (b)

7) Frete Marítimo em US $\$ / t$

8) Preço FOB na Argentina em US\$/t (5 - 6 - 7)

9) Preço FOB na Argentina em US $\$ /$ bushel $\left(8^{*} 0,0272154\right)$

10) Chicago US\$/bushel (c)

11) Prêmio mínimo na Argentina (US\$/bushel) (9-10)
VALOR

185,0

10,0

175,0

4,00

171,0

3,0

16,0

152,0

4,1368

4,5750

$-0,44$

Fonte: Dados da pesquisa

(a) Rendimento da soja em farelo: $78 \%$; rendimento em óleo: $20 \%$

(b) FOG (For Our Guidance)

(c) Sobre o primeiro vencimento da CBOT

Nas simulações mostradas nas tabelas 12, 13 e 14, o prêmio é determinado, na visão do importador, através unicamente do custo de transferência do porto de origem até a fábrica de ração na Europa. Este raciocínio é possível, já que a relação entre o preço em Roterdã e no Brasil é unicausal, de fora para dentro, conforme demonstrado por Margarido et al (2000).

Para o importador, o prêmio é um mecanismo que equaliza o custo de aquisição da soja entre os diversos pontos de abastecimento. Desta forma, não importa se a soja é originada no Brasil, EUA ou Argentina, o prêmio permitirá que o produto chegue com o mesmo custo no porto Europeu. Para tanto, o prêmio máximo que o importador estaria disposto a pagar no Golfo do México seria de -US\$ 0,25/bu, -US\$0,36/bu em Paranaguá, e de -US\$ 0,44/bu em Buenos Aires. Entretanto, o importador poderá ter necessidade de um produto específico, como o caso de um farelo de maior teor protéico, e para obtê-lo, estará disposto a pagar um prêmio maior, até um determinado limite onde valerá a pena substituir na formulação da ração um produto de qualidade protéica menor. 
Outro ponto a ressaltar neste exemplo é que o frete marítimo foi o fator variável de um ponto de abastecimento para outro. O custo do frete está diretamente ligado à distância marítima entre o ponto de origem e destino. Contudo, o frete também é influenciado pela eficiência do porto de origem, isto é, espera-se que para portos que tenham a mesma distância até o ponto de destino, aquele mais eficiente (como por exemplo menor tempo de espera para embarque), o frete possa ser menor. Assim, qualquer variável que altere a eficiência do porto tende a elevar ou reduzir o prêmio pago naquele porto, quando comparado aos demais. Para o mesmo porto, a perda de eficiência ao longo do tempo pode levar a redução do prêmio pago.

Outra variável importante na determinação do prêmio é o seguro da carga FOG (For Our Guidance). O FOG é um seguro pago pelo importador e tem sua contrapartida na garantia a este agente de que o produto embarcado no ponto de origem será o mesmo desembarcado no ponto de destino. No exemplo foi considerado o mesmo para o Brasil, EUA e Argentina mas, na prática, este valor pode variar.

\subsubsection{A soja transgênica e o prêmio}

Características especiais da soja, como a ausência de grãos transgênicos ou maior teor de proteína, não são incluídas na negociação do prêmio. Contudo, ao escolher o porto onde a soja vai ser adquirida, o comprador conhece as características do produto normalmente embarcado ali. Assim, a soja embarcada nos porto de Rio Grande, produzida no estado de Rio Grande do Sul, onde o teor de proteína da soja é menor que a produzida nos outros estados, o prêmio deste tende a ser menor que nos demais estados.

O mesmo efeito se tem para a soja transgênica. Para adquirir soja não transgênica, o comprador opta por se abastecer em portos não localizados no Rio Grande do Sul, onde o risco de compra de soja geneticamente modificada é maior que no demais estados, o que pode reduzir o prêmio neste porto quando comparado aos demais. Como exemplo, tem-se o caso de uma cooperativa exportadora de grãos no Brasil, que está fechando um contrato de exportação com uma indústria esmagadora na China. Imagine- 
se que haja leis específicas naquele país, impedindo o consumo deste tipo de soja, o que geraria uma demanda por produto não transgênico. Normalmente o país teria três principais fontes de abastecimento: Estados Unidos, Brasil e Argentina. Contudo, a maior parte da soja produzida nos EUA e na Argentina é transgênica, restando apenas a opção de abastecimento do Brasil, onde a produção de soja geneticamente modificada é proibida. Assim, o importador evitará comprar soja nos portos do Rio Grande do Sul, centralizando a demanda nos demais portos brasileiros, o que ao longo do tempo reduziria o prêmio pago na exportação da soja do Rio Grande do Sul. Infelizmente não estão disponíveis séries históricas de prêmio neste estado, o que impede aprofundar a análise. Contudo, há sinais de que são pagos adicionais na exportação de soja com rastreabilidade e não transgênica. Estes valores seriam somados ao prêmio e à cotação da bolsa de Chicago para formar o preço de exportação.

\subsubsection{Determinação do prêmio: exportador versus importador}

O prêmio teórico desejado pelo importador nem sempre será suficiente para tornar a exportação a operação mais rentável para o exportador. Imagine o caso de uma indústria nos EUA, que pode escolher entre vender a soja ou derivados no mercado interno ou externo. Quanto maior a rentabilidade das operações no mercado americano, devido ao aumento da demanda interna ou redução na disponibilidade do produto, maior terá de ser o valor do prêmio para viabilizar a exportação daquela fonte. Neste caso, o importador procurará se abastecer no Brasil ou na Argentina, aumentando a dependência do abastecimento do importador desses dois países. Contudo, a maior demanda pelos produtos da Argentina e do Brasil fará com que o valor do prêmio se eleve. Se não ocorrer a exportação, o prêmio tenderá a se elevar até que viabilize a importação de produtos substitutos. Por esta razão, a disponibilidade de produtos substituta ao farelo e do óleo de soja altera os valores de prêmio.

Como exemplo, imagine o caso de uma cooperativa no Brasil, que tem como alternativa de comercialização a venda do grão e derivados no mercado interno e externo. No caso de um aumento da demanda interna, por uma elevação no alojamento 
de aves por exemplo, o prêmio tenderá a se elevar, para viabilizar a exportação. A redução da oferta de farelo brasileiro no mercado internacional deve afetar também o preço na bolsa de Chicago, mas mais lentamente e em menor intensidade.

Em síntese, o prêmio dependerá em grande medida da necessidade do importador e da rentabilidade das alternativas de comercialização do exportador e também da disponibilidade de produtos substitutos. Vale notar que o preço da soja no ponto de consumo é medido pelo valor nutricional relativo da soja na formulação de rações animais, comparado às demais fontes protéicas. 


\section{METODOLOGIA}

\subsection{Cálculo dos preços FOB}

A soma das cotações da CBOT para determinado vencimento e dos prêmios define o preço FOB para determinada região. Em cada dia de negociação, é possível calcular diferentes preços $\mathrm{FOB}$, pois, como mostrado anteriormente, para a mesma data estão disponíveis cotações para diferentes vencimentos futuros e diferentes prêmios para embarque futuro.

Foram montadas três séries, para cada dia de negociação, seguindo o procedimento apresentado na Tabela 15.

Tabela 15. Séries diárias de preços FOB: meses de referência para o valor do prêmio de exportação da soja e do vencimento futuro da Bolsa de Chicago.

\begin{tabular}{cccc}
\hline Período & Série 1 & Série 2 & Série 3 \\
\hline 15/jan a 14/mar & Março & Maio & Julho \\
15/mar a 14/mai & Maio & Julho & Agosto \\
15/mai a 14/jul & Julho & Agosto & Setembro \\
15/jul a 14/ago & Agosto & Setembro & Novembro \\
15/ago a 14/set & Setembro & Novembro & Janeiro \\
15/set a 14/nov & Novembro & Janeiro & Março \\
15/nov a 14/jan & Janeiro & Março & Maio \\
\hline
\end{tabular}

Fonte: Dados da pesquisa

Vale a pena ressaltar que na montagem das séries, tanto o prêmio quanto a cotação de Chicago se referem ao mesmo mês. Como exemplo, no período de 15 de janeiro a 14 
de março, a "série 1" é composta pela cotação da CBOT para o contrato com vencimento em março, somado ao prêmio para embarque no mesmo mês. Neste mesmo período, a "série 2" é composta pela cotação da CBOT para o contrato com vencimento em maio, somado ao prêmio para embarque no mesmo mês.

Uma quarta série, chamada "FOB SPOT", é composta pelo preço FOB mais próximo, isto é, determinada pelo prêmio para o embarque mais próximo. Como exemplo, em 05 de abril, o prêmio mais próximo seria para embarque em abril sobre o contrato da CBOT com vencimento em maio do mesmo ano.

\subsection{Teste de Raiz Unitária}

Para verificar a estacionariedade das séries temporais deste trabalho, será utilizado o teste denominado Dickey-Fuller Aumentado (DFA), desenvolvido por Fuller (1976) e Dickey \& Fuller (1979), conforme descrito por Enders (1995).

O teste de raiz unitária de Dickey-Fuller consiste em verificar a ordem de integração de uma série temporal, para testar a estacionariedade da série detectando ou não a existência de raiz unitária.

A diferença entre o teste Dickey Fuller e o teste Dickey Fuller Aumentado reside no fato de que no primeiro caso testa-se a existência ou não da raiz unitária para o seguinte modelo de regressão:

$$
Y_{t}=\alpha+\beta_{t}+\tilde{n} y_{t-1}+u_{t}
$$

Na segunda situação, testa-se a equação (2) em que incorporam-se na regressão valores defasados da variável endógena $\left(Y_{t}\right)$ a fim de se eliminar problemas de autocorrelação entre os termos de erro. 
Um dos problemas encontrados é a determinação do valor de $\mathrm{p}$ (número de defasagens). Maddala (1992) sugere que a dimensão das defasagens é, em certo sentido, arbitrária. Isso porque existe uma variedade de métodos alternativos para se determinar o nível ótimo das defasagens em um modelo. Segundo Bacchi ${ }^{4}$ (1996), dentre os procedimentos que têm sido utilizados para a determinação do valor de $\mathrm{p}$, pode-se citar os critérios de AIC (AKAIKE Information Criteron) e SC (SCHWARZ Criterion). São eles:

AIC: $\ln \hat{\sigma}^{2}+\left(\frac{2}{T}\right)$ (número de parâmetros)

SC: $\ln \hat{\sigma}^{2}+\left(\frac{L n T}{T}\right)$ (número de parâmetros)

com $\hat{\sigma}^{2}$ sendo a soma dos quadrados dos resíduos de uma série descrita por um processo auto-regressivo de ordem $\mathrm{p}$, isto é, $X_{t}=\rho_{1} X_{t-1}+\ldots+\rho_{p} X_{t-p}+e_{t}$, dividida por $\mathrm{T}$ (número de observações). Partindo de uma especificação geral para a equação acima, (12 defasagens da variável dependente, por exemplo, se a série de dados utilizada for mensal), são feitos ajustamentos sucessivos tomando-se como o modelo mais adequando aquele que apresentar o menor valor para os critérios AIC e SC.

Davidson \& MacKinnon (1993) argumentam que a escolha de um número elevado de defasagens seria preferível, uma vez que dessa forma pode-se verificar como a exclusão de algumas defasagens afeta o resultado das estimações. Além disso, a escolha de poucas defasagens pode causar um sério viés devido à omissão de variáveis relevantes (estimador de mínimos quadrados das variáveis que permanecem serão inconsistentes e as variância e erros-padrão desses coeficientes serão incorretamente

\footnotetext{
${ }^{4}$ BACCHI, M.R. Integração, co-integração e modelo de correção de erro: uma introdução. Escola Superior de
} Agricultura Luiz de Queiroz. 1996. 
calculados); por outro lado, a escolha de mais defasagens do que o necessário pode levar ao viés de inclusão de variáveis irrelevantes, que é menos sério do que no caso anterior (os coeficientes podem ser estimados consistentemente pelo método de mínimos quadrados, mas tendo-se em mente que suas variâncias podem ser menos eficientes).

O valor de $\mathrm{p}$ pode também ser obtido utilizando a seguinte sistemática: partindo de uma especificação geral, se o coeficiente do último termo apresentar-se não significativo reduz-se a ordem da regressão estimada até que o coeficiente do termo correspondente à defasagem de maior ordem incluída apresente-se significativo. Se o coeficiente de nenhum termo é significativo, então p=1 (Campbell e Perron, 1991, citado por Bacchi, 1996).

Neste trabalho, para a determinação do número de defasagens da variável dependente foram utilizados os critérios de AKAIKE \& SCHWARZ. Para as demais variáveis foi utilizado o segundo método apresentado.

Generalizando, para séries com processo auto-regressivo de ordem p, $\{\operatorname{AR}(\mathrm{p})\}$, tem-se:

$\Delta Y_{\mathrm{t}}=\alpha+\beta \mathrm{t}+\eta Y_{\mathrm{t}-1}+\sum_{\mathrm{i}=1}^{\mathrm{p}-1} \omega_{\mathrm{i}} \Delta Y_{\mathrm{t}-\mathrm{i}}+\varepsilon_{\mathrm{t}}$

com

$$
\eta=\sum_{i=1}^{p} \rho_{i}-1 \text { e } \omega_{i}=-\sum_{j=i+1}^{p} \rho_{j}
$$

Utilizando a metodologia proposta por Enders (1995), numa primeira etapa, testase a hipótese Ho: $\eta=0$, se não for rejeitada tem-se $p_{i}=1$ indicando a presença de raiz 
unitária. $\mathrm{O}$ procedimento usual consiste em calcular o valor de $\mathrm{t}$ (procedimento igual ao teste $t$ de student). Porém, para este teste, deve-se usar tabelas especiais $\left(\tau, \tau_{\mu} \mathrm{e} \tau\right.$. ) com valores críticos. Se o valor calculado, em módulo for menor que o valor do para um dado nível de probabilidade, então não se rejeita a hipótese que existe raiz unitária (hipótese nula). A estatística $\tau_{\tau}$ analisa o valor de $\eta$ no modelo. A estatística $\tau_{\beta \tau}$ testa a presença de uma tendência determinística quadrática na série, testando se o coeficiente $\beta$ é estatisticamente igual a zero. Se esses testes forem não-significativos, realiza-se a segunda etapa do processo.

A segunda etapa consiste no modelo sem a variável tendência apenas com a constante. Analisando o valor da constante com a hipótese Ho: constante $=0$ e analisa o valor de $\rho$ com a estatística $\tau_{\mu}$ (tendência estocástica e determinística). Com o resultado sendo não significativo realiza-se a terceira etapa do processo, que consiste no modelo sem a constante. Com isso testa-se novamente a hipótese de $\eta=0$ com a estatística $\tau$. Sendo o resultado não-significativo, não se rejeita a hipótese nula. Conclui-se então que a série tem raiz unitária e o modelo apresenta uma tendência estocástica. Caso isto ocorra, é necessário acrescentar mais uma diferença verificando a estacionariedade na série. Se a hipótese mais uma vez não for rejeitada, repete-se o processo aumentado o numero de diferenças até que o teste seja significativo. Para cada uma raiz unitária temse a necessidade de uma ordem de diferença a mais.

\subsection{Teste de Causalidade}

O teste de sentido de causalidade de Granger (1969) supõe que as informações relevantes para a previsão das respectivas variáveis, $\mathrm{X}$ e $\mathrm{Y}$, estão contidas exclusivamente nos dados de séries temporais destas variáveis. O teste envolve a estimativa das seguintes regressões:

$$
X_{t}=\alpha+\sum_{i=1}^{k_{1}} \alpha_{i} Y_{t-i}+\sum_{j=1}^{k_{2}} \beta_{j} X_{t-i}+u_{1 t}
$$


$Y_{t}=\alpha+\sum_{i=1}^{k_{3}} \lambda_{i} X_{t-i}+\sum_{j=1}^{k_{4}} \delta_{j} Y_{t-i}+u_{2 t}$

em que se supõe que os resíduos $u_{1 t}$ e $u_{2 t}$ são não-correlacionados.

A equação (4) postula que valores contemporâneos de $X$ são relacionados com valores passados de $\mathrm{X}$ e também de $\mathrm{Y}$, e a equação (5) postula um comportamento similar para $\mathrm{Y}_{\mathrm{t}}$.

As possíveis relações de causalidade entre duas variáveis, X e Y, são:

(a) Causalidade unidirecional de $\mathrm{X}$ para $\mathrm{Y}$ (X Y). Esta relação é indicada se os coeficientes estimados sobre o X defasado em (4) forem estatisticamente diferentes de zero como um grupo (isto é $\sum \alpha_{i} \neq 0$ ) e o conjunto dos coeficientes estimados sobre o $\mathrm{Y}$ defasado em (5) não forem estatisticamente diferentes de zero (isto é, $\sum \boldsymbol{\delta}_{j}=0$ ).

(b) Causalidade unidirecional de $\mathrm{Y}$ para $\mathrm{X}$ ( $\mathrm{Y} \mathrm{X}$ ). Esta relação é indicada se o conjunto de coeficientes defasados de $\mathrm{Y}$ em (4) não for estatisticamente diferente de zero (isto é, $\sum \alpha_{i}=0$ ) e o conjunto dos coeficientes defasados de $\mathrm{X}$ em (29) for estatisticamente diferente de zero (isto é, $\sum \boldsymbol{\delta}_{j} \neq 0$ ).

(c) Causalidade bilateral, quando $\mathrm{X}$ e $\mathrm{Y}$ são mutuamente relacionados quanto à direção de causalidade (X Y). Esta relação ocorre quando os conjuntos de coeficientes de $\mathrm{X}$ e $\mathrm{Y}$ são estatisticamente diferentes de zero em ambas as regressões.

(d) Ausência de causalidade entre as duas variáveis. Esta relação ocorre quando os conjuntos de coeficientes de $\mathrm{X}$ e $\mathrm{Y}$ não são estatisticamente significativos (são estatisticamente iguais a zero) em ambas as regressões. 


\subsection{Fonte dos dados}

Os dados utilizados são prêmios de exportação da soja em grão para o porto de Paranaguá, Paraná, obtidos junto a agentes do mercado. Entre 1993 e 1995 os dados disponíveis são semanais e de 1996 a 2001 são diários.

Para as cotações de soja no mercado internacional foram utilizadas as da Bolsa de Chicago (CBOT).

Para a taxa de câmbio, foi utilizada a série do dólar comercial (venda), disponibilizada pelo Banco Central do Brasil.

Para os estoques mensais de soja no Brasil, foram utilizados os dados da Companhia Nacional de Abastecimento (CONAB).

Para os estoques mensais de soja na Argentina, foram utilizados dados da Secretaría de Agricultura, Ganadería, Pesca y Alimentos da Argentina.

Os estoques mensais de soja nos Estados Unidos foram estimados a partir dos dados divulgados pelo Departamento de Agricultura dos Estados Unidos (USDA).

Para o estoque diário de soja no porto de Paranaguá, foram utilizados os relatórios semanais de movimentação portuária (line up), divulgados Agência Estado.

Os valores de frete para o farelo, óleo e grão foram obtidos junto ao Sistema de Informações de Fretes (Sifreca)

Os dados de precipitação em Antonina, Paraná - próximo à Paranaguá - foram levantados junto ao Instituto Tecnológico SIMEPAR.

Para os preços internos do farelo e óleo de soja, foram utilizados os dados apurados pelo Departamento de Economia Rural (Deral), da Secretaria de Agricultura do Paraná. 


\section{RESULTADOS E DISCUSSÃO}

\subsection{O mercado de prêmio}

Seguindo o procedimento mostrado na Tabela 5 (metodologia), foram compostas as séries de preço $\mathrm{FOB}$, do prêmio e uma série indicando o percentual do preço CBOT representado pelo prêmio.

\subsubsection{O preço FOB Paranaguá}

Para cada dia de negociação são determinados vários preços FOB, dependendo do contrato futuro e prêmio escolhidos. Isto se deve ao fato de em um mesmo dia serem negociados prêmios para diversos embarques e cotações internacionais para diferentes vencimentos. Como exemplo, em setembro, são negociados prêmios para setembro, novembro, março, etc., podendo inclusive ser negociado prêmio para setembro do próximo ano. Da mesma frma, para setembro são negociados na CBOT contratos para diferentes vencimentos, inclusive setembro do próximo ano. A combinação das diferentes alternativas de prêmio e contrato da CBOT permite a construção de diferentes séries de preço FOB. Após a montagem dessas séries, será determinado qual dos preços FOB possui uma relação mais significativa com os preços internos.

As quatro séries de preço FOB, como indicado na metodologia, são:

Série 1: Premio e contrato da CBOT para o primeiro vencimento da CBOT. 
Série 2: Prêmio e contrato da CBOT para o segundo vencimento da CBOT.

Série 3: Prêmio e contrato da CBOT para o terceiro vencimento da CBOT.

Série 4: Prêmio e contrato da CBOT para o embarque mais próximo (FOB SPOT).

O comportamento das quatro séries pode ser observado nas figuras 5 a 8 .

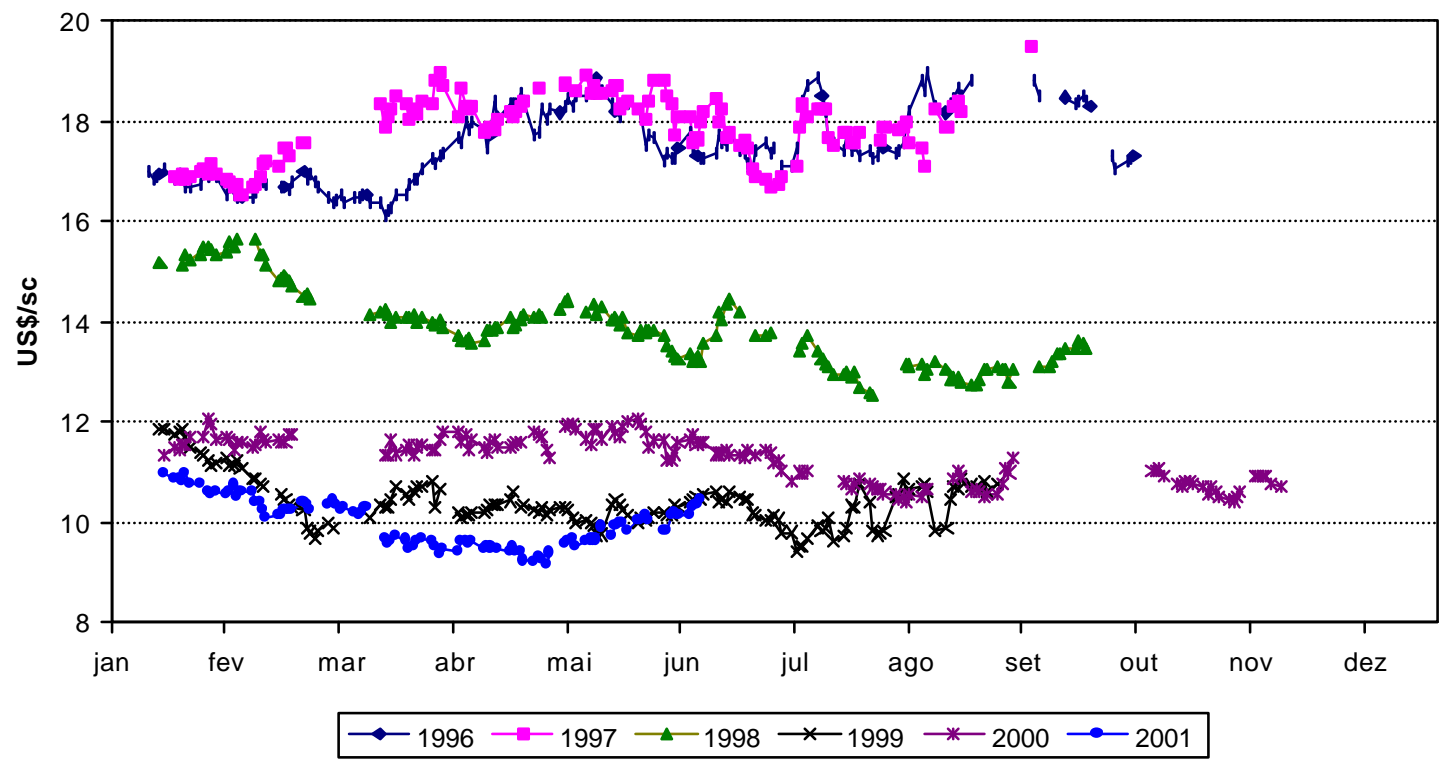

Figura 5 - Evolução do preço FOB Paranaguá (série 1) entre 1996 e 2001. Valores em dólar por saca de $60 \mathrm{Kg}$. 


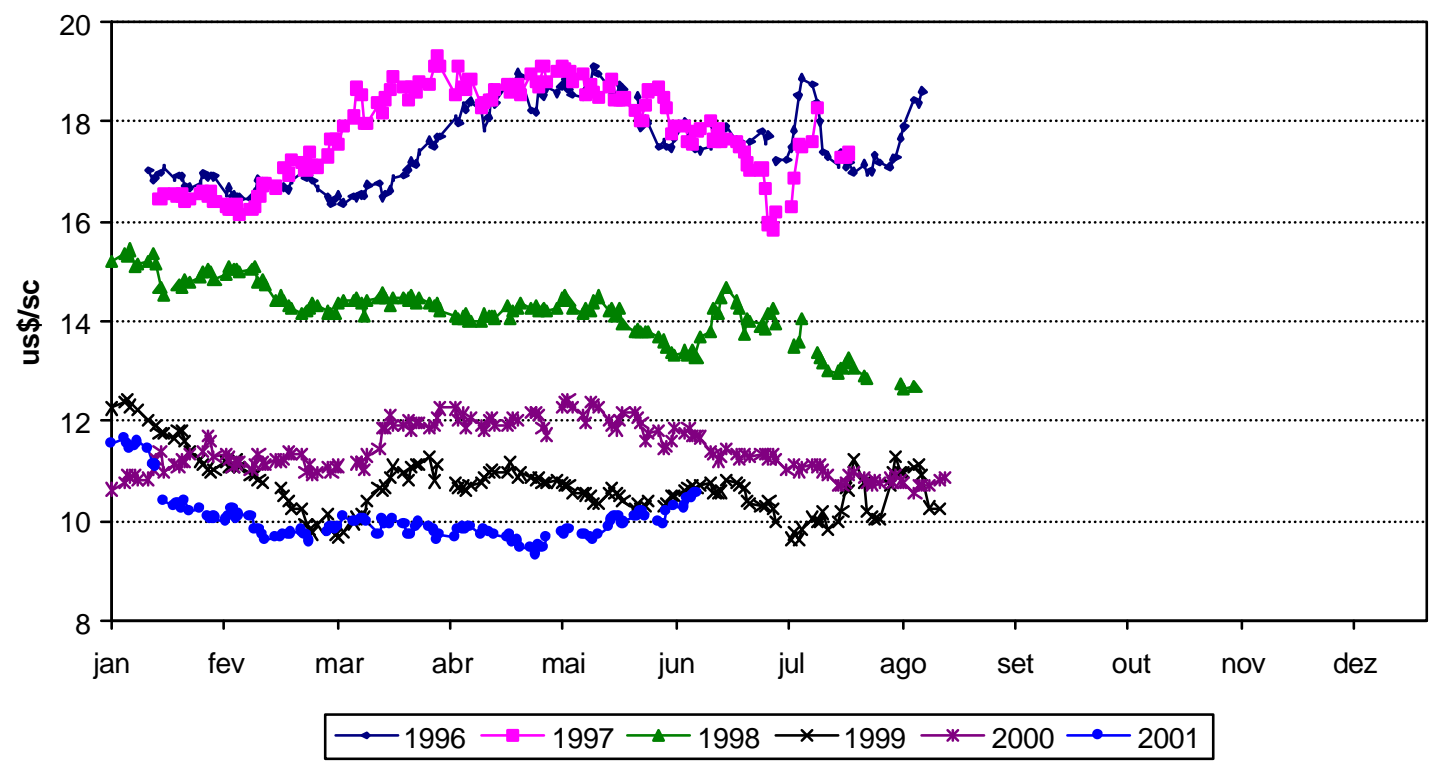

Figura 6 - Evolução do preço FOB Paranaguá (série 2) entre 1996 e 2001. Valores em dólar por saca de $60 \mathrm{Kg}$.

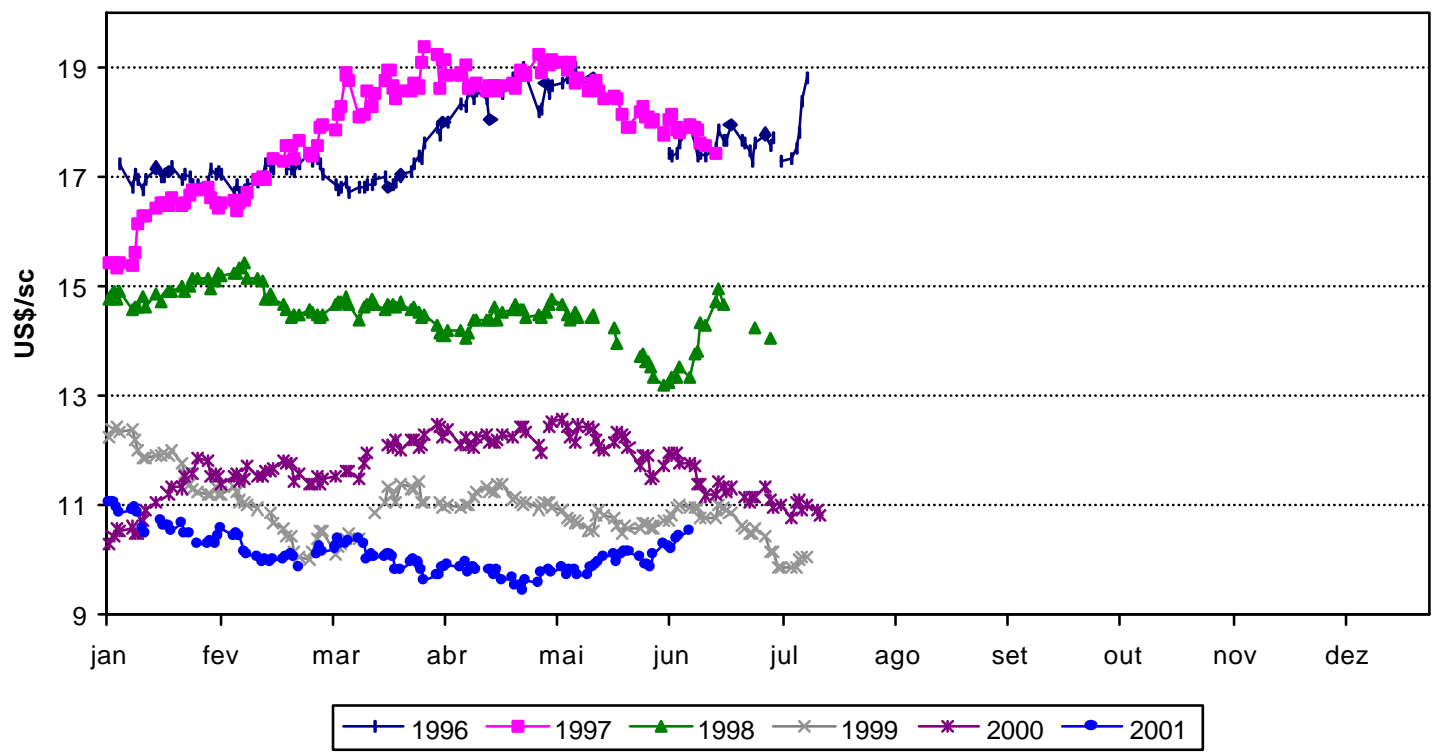

Figura 7 - Evolução do preço FOB Paranaguá (série 3) entre 1996 e 2001. Valores em dólar por saca de $60 \mathrm{Kg}$ 


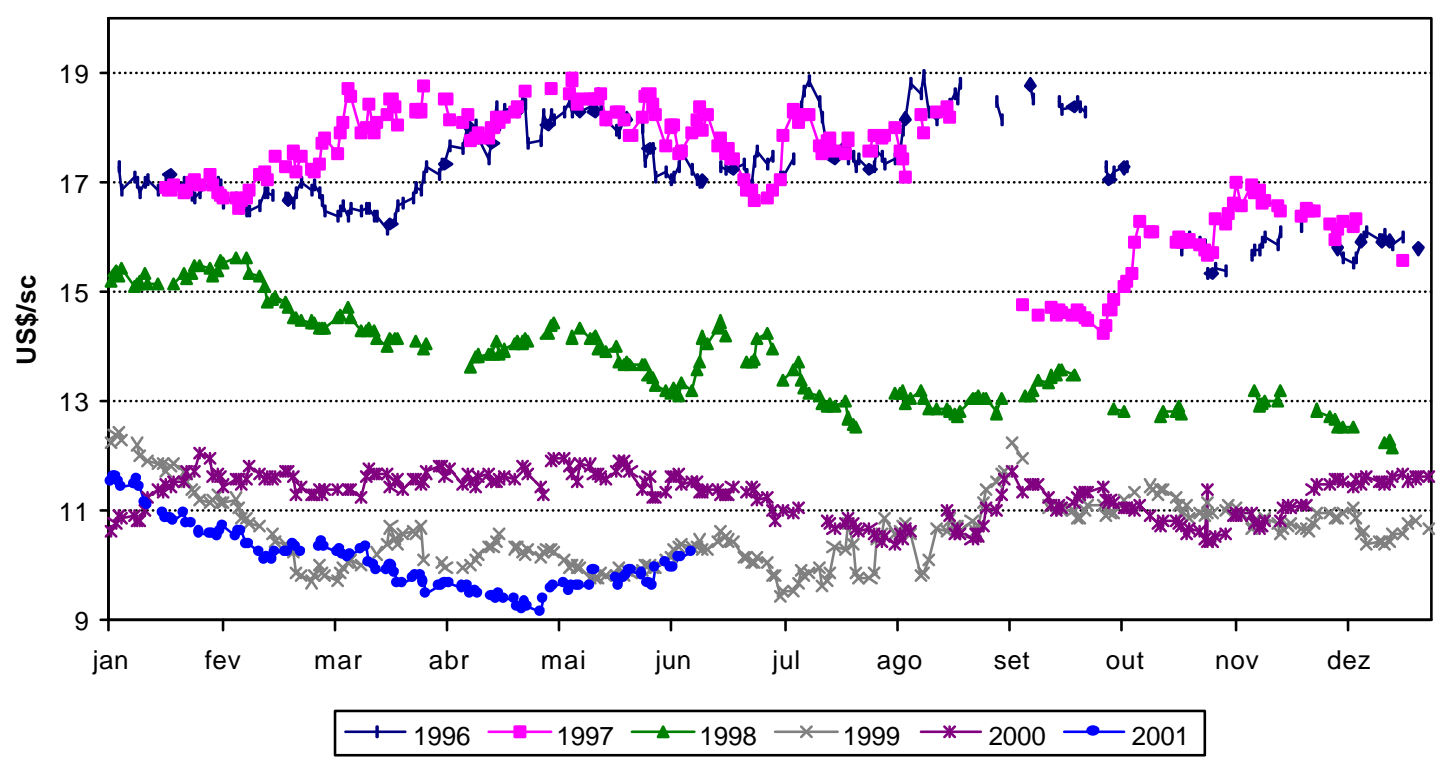

Figura 8 - Evolução do preço FOB Paranaguá (série 4) entre 1996 e 2001. Valores em dólar por saca de $60 \mathrm{Kg}$.

As figuras 5 a 8 mostram a evolução do preço FOB de 1996 a 2001 ao longo do ano. A distância vertical entre as séries é semelhante, devendo-se às variações das cotações da CBOT. Para as séries 2 e 3 foram eliminados os preços FOB de setembro a novembro de cada ano, já que para este período o preço FOB se refere à comercialização da safra seguinte. Como exemplo, o preço FOB para a série 3 é a soma entre o prêmio para embarque em março e a cotação da CBOT para o contrato com vencimento também em março, período de colheita da safra seguinte.

Da mesma maneira que as séries de preço FOB foram compostas, foram construídas quatro séries de prêmio, podendo-se assim desagregar o efeito deste das variações das cotações da CBOT. O comportamento do prêmio pode ser visto nas figuras 9 a 12. 


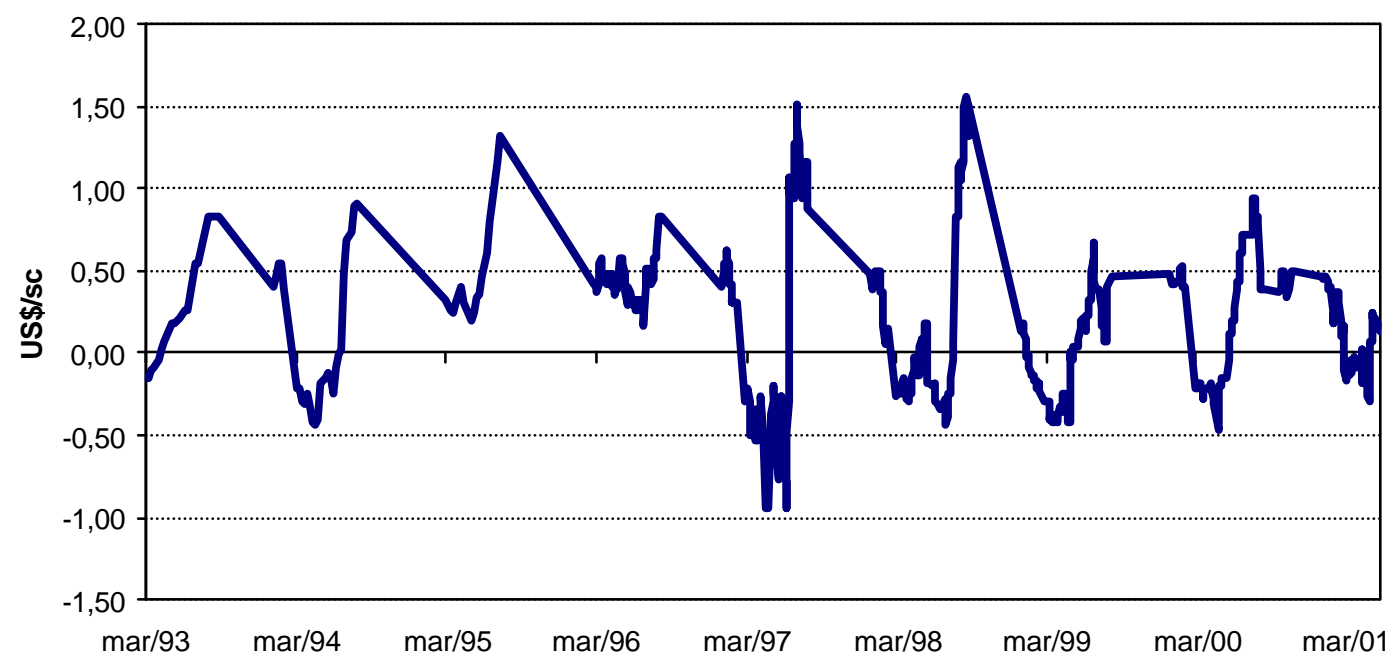

Figura 9 - Evolução do prêmio de exportação da soja em Paranaguá - série 1. Valores em dólar por saca de $60 \mathrm{Kg}$.

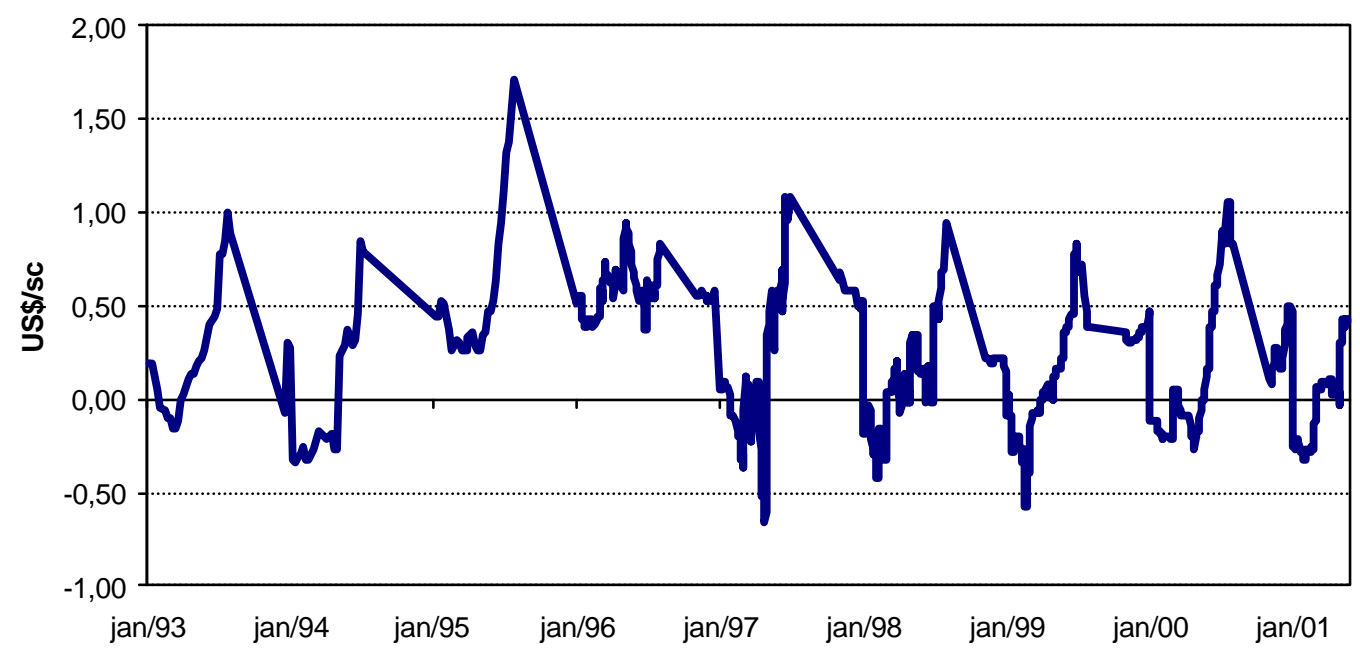

Figura 10 - Evolução do prêmio de exportação da soja em Paranaguá - série 2. Valores em dólar por saca de $60 \mathrm{Kg}$. 


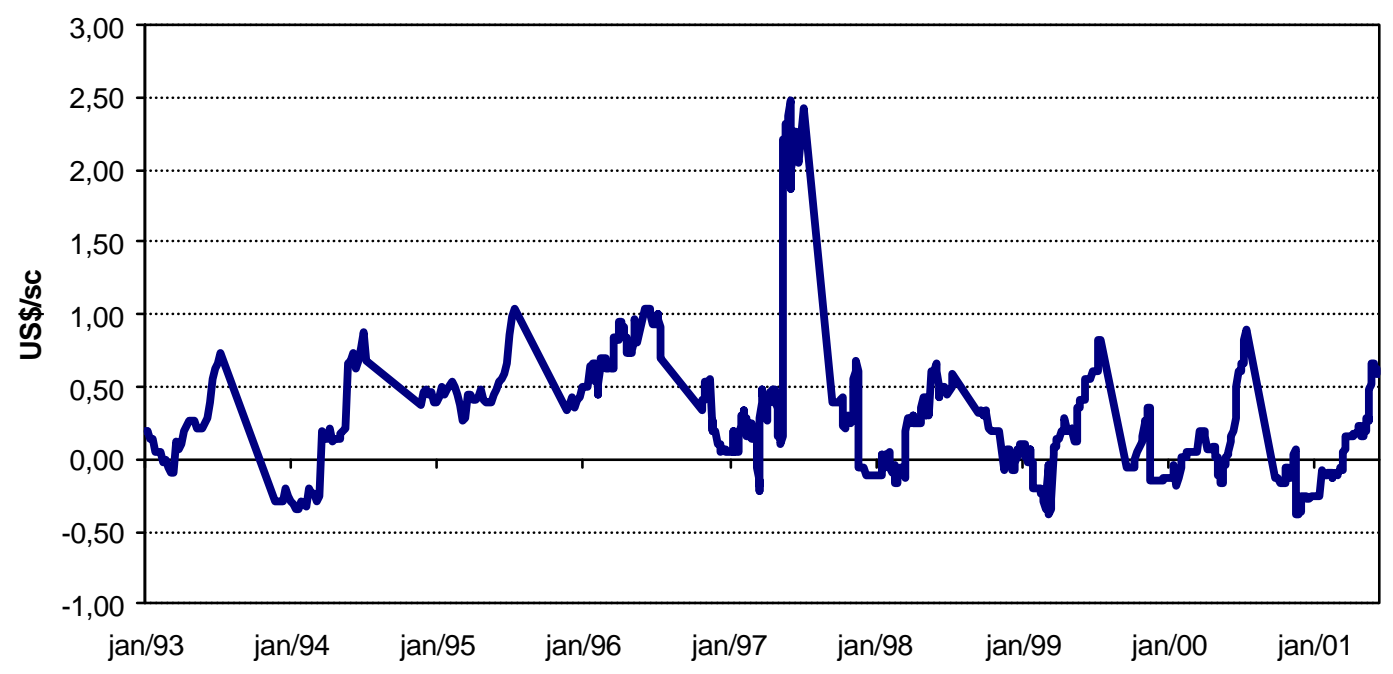

Figura 11 - Evolução do prêmio de exportação da soja em Paranaguá - série 3. Valores em dólar por saca de $60 \mathrm{Kg}$.

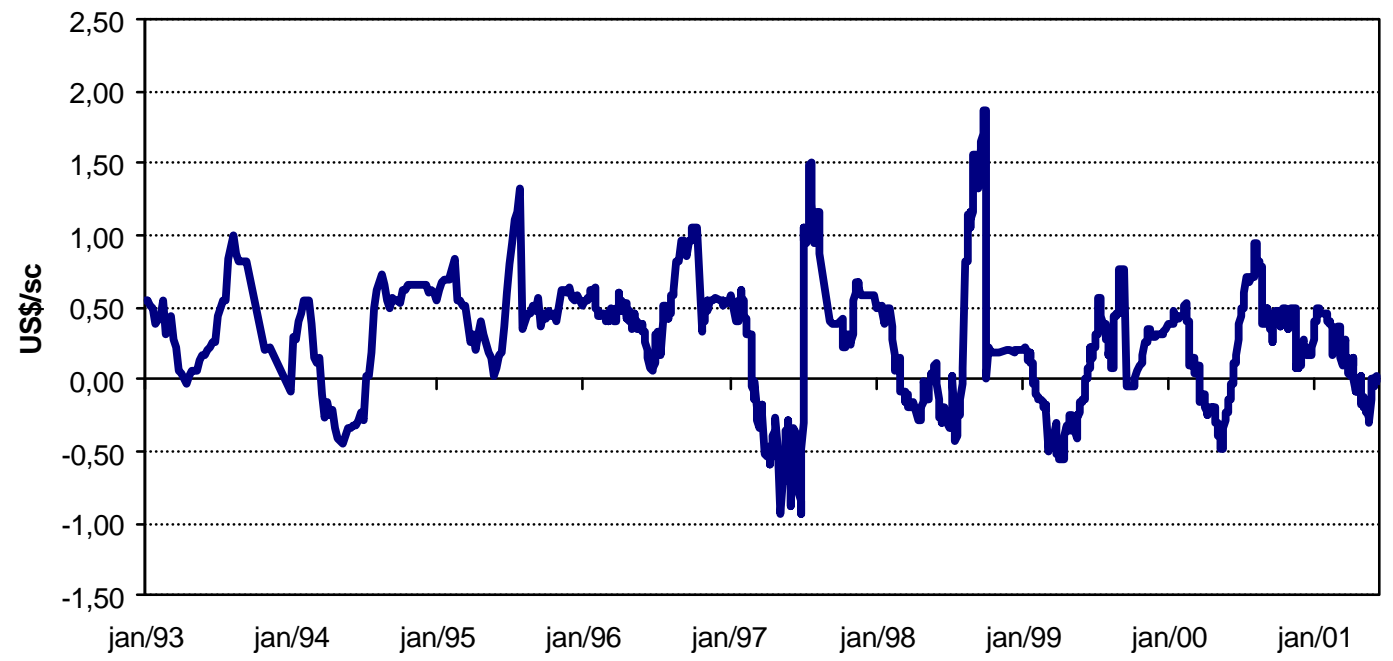

Figura 12 - Evolução do prêmio de exportação da soja em Paranaguá - série 4. Valores em dólar por saca de $60 \mathrm{Kg}$.

A análise para estas séries pode ser feita de maneira conjunta, já que elas possuem comportamento semelhante, com queda no valor do prêmio no período de safra e elevação na entressafra. 
Para todas as séries, o prêmio para embarque de março a junho apresenta uma clara tendência de queda em função do período de colheita e embarques, intensificandose a oferta de soja tanto no Brasil quanto na Argentina. A partir de agosto há tendência de elevação do prêmio pela redução da quantidade de soja disponível para embarque, tanto no Brasil como na Argentina. No segundo semestre o prêmio assume valores mais altos, já que o volume de soja disponível para exportação é pequeno e parte da soja produzida nos Estados Unidos foi colhida, limitando as alternativas de compra dos importadores, fazendo com que estes paguem prêmio mais altos para adquirir a soja em estoque e, por outro lado, os exportadores exigem prêmios maiores para exportar o produto e não vendê-lo no mercado interno. O calendário agrícola da soja nos três principais países produtores é apresentado na Tabela 16.

Tabela 16. Calendário agrícola da soja nos Estados Unidos, Argentina e Brasil, média dos últimos cinco anos safra.

\begin{tabular}{lcccccccccccc}
\hline País & Jan & Fev & Mar & Abr & Mai & Jun & Jul & Ago & Set & Out & Nov & Dez \\
\hline EUA & & & & & & & & & & & & \\
$\quad \begin{array}{l}\text { Plantio } \\
\text { Colheita }\end{array}$ & & & & $5 \%$ & $60 \%$ & $100 \%$ & & & & & & \\
Argentina & & & & & & & & & $20 \%$ & $85 \%$ & $100 \%$ & \\
$\quad$ Plantio & $100 \%$ & & & & & & & & & $2 \%$ & $39 \%$ & $90 \%$ \\
Colheita & & $1 \%$ & $18 \%$ & $32 \%$ & $70 \%$ & $85 \%$ & $100 \%$ & & & & & \\
Brasil & & & & & & & & & & & & \\
$\begin{array}{l}\text { Plantio } \\
\text { Colheita }\end{array}$ & $100 \%$ & & & & & & & & $2 \%$ & $35 \%$ & $88 \%$ & $97 \%$ \\
\hline
\end{tabular}

Fonte: Canziani \& Guimarães (2002)

Como o prêmio varia com a disponibilidade de produto, este teria um comportamento sazonal na opinião dos agentes entrevistados. No entanto, esta análise não foi feita até o momento. A análise do comportamento estacional do prêmio para o embarque mais próximo é apresentada na Figura 13. 


\subsubsection{Padrão sazonal do prêmio ${ }^{5}$}

A Figura 13 apresenta o padrão sazonal do prêmio e o índice de irregularidade, calculados a partir de médias mensais entre 1993 e 2001. O índice sazonal mostra, para cada mês do ano, o quanto o prêmio está, em média, acima ou abaixo do valor médio do ano. Ele não só indica a variação ao longo do ano, mas permite medir a variação média pois são índices comparáveis. O grau de dispersão (variabilidade) do índice para cada mês é determinado através do índice de irregularidade e a intensidade da dispersão medida pelo desvio padrão dos índices sazonais.

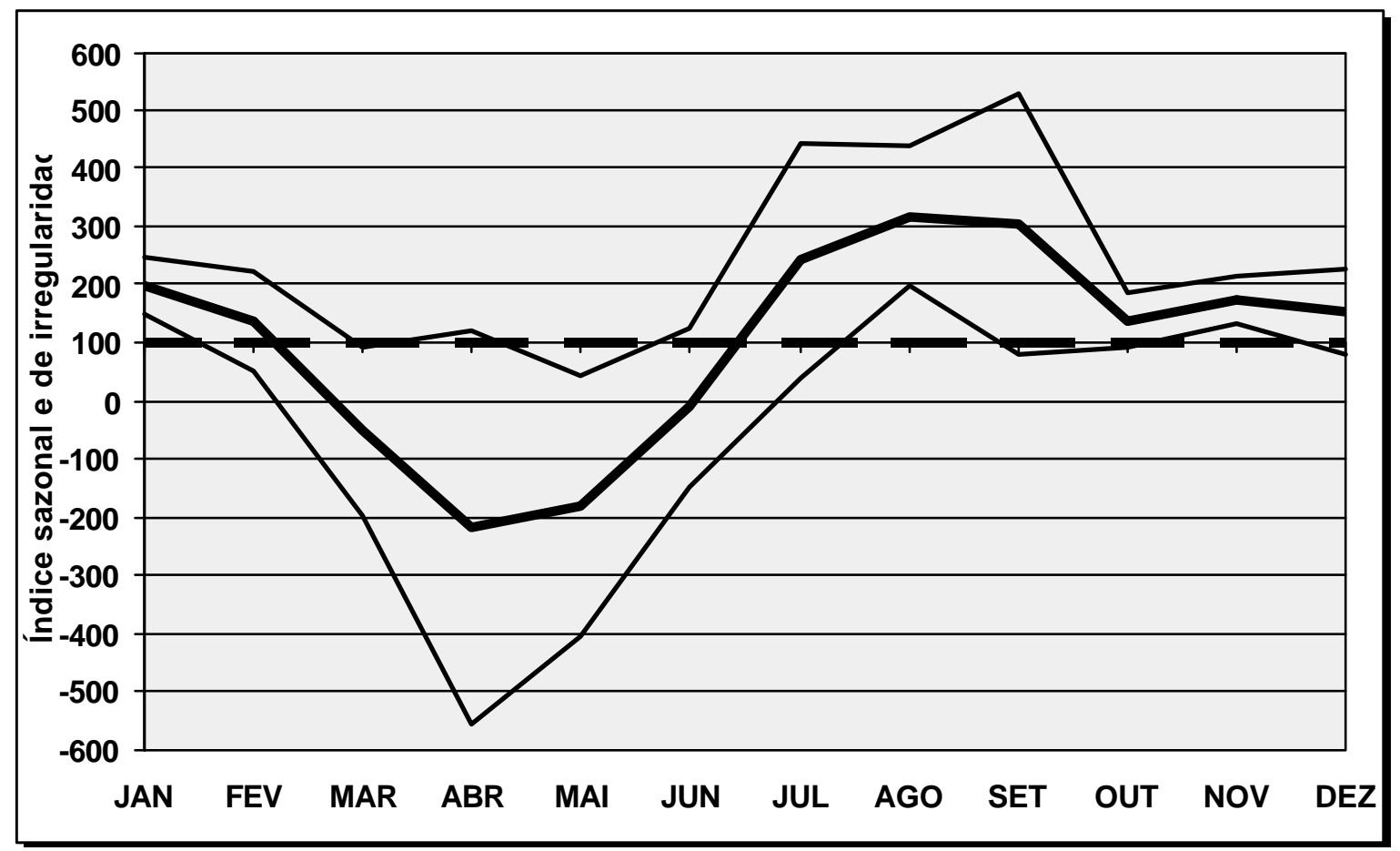

Figura 13 - Padrão sazonal do prêmio de exportação da soja em grão pelo porto de Paranaguá, Paraná, 1993 a 2001.

Fonte: Dados da pesquisa

${ }^{5}$ O padrão sazonal do prêmio foi definido utilizando-se a metodologia apresentada por Hoffmann (1980). 
A estimativa do componente estacional mostra a existência de uma grande variabilidade. Como a magnitude do prêmio é pequena e assume valores positivos e negativos, a variação relativa é alta, resultando em elevados níveis ,do índice de irregularidade. Na Figura 13 nota-se que os valores mais baixos são normalmente observados em abril. Nesse mês, o prêmio fica 319,15\% abaixo da média do ano, ficando em junho próximo da média e atingindo o máximo em agosto, quando os valores ficam normalmente $218,33 \%$ acima da média. A estimativa do componente estacional é superior a média (sinal positivo) nos meses de julho a fevereiro.

Este comportamento do prêmio está diretamente ligado à disponibilidade de produto no mercado interno, isto é, à medida que a soja é colhida, os prêmios se reduzem, atingindo o menor valor no pico da colheita. Estima-se que no final de abril cerca de $90 \%$ da área esteja colhida. Em setembro a disponibilidade de produto e as exportações diminuem. Com a escassez de produto, o prêmio se mantém acima da média até fevereiro. Em março, com o início da colheita da soja, o prêmio fica abaixo da média até junho.

Os índices de irregularidade indicam que os meses de setembro e abril são os que apresentam maior variabilidade. Em setembro, a diferença entre os limites superior e inferior do índice de irregularidade é de 449,37\%. Neste momento os prêmios seriam influenciados pela indefinição da área de soja, que começa a ser plantada em setembro, e vai determinar, em grande medida, a disponibilidade do produto para embarque a partir de março. Em abril, a diferença entre o índice de irregularidade superior e inferior é de $677,33 \%$, o que é justificado pela diferença no período de colheita entre os anos. Em anos quando a colheita é antecipada, há maior disponibilidade de soja para embarque em abril e maio. Em anos quando a colheita atrasa, a disponibilidade de produto para embarque em abril e maio é menor, alterando, conseqüentemente, o valor dos prêmios neste período, refletindo em alta dispersão do índice em abril. A intensidade da dispersão, medida pelo desvio padrão do índice sazonal para cada mês é de 177,41. 
O padrão sazonal do prêmio, conforme mostrado na Figura 13 é estatisticamente significativo. Usando-se variáveis binárias para cada mês, no período de janeiro de 1993 a março de 2002, e tendo como mês de referência dezembro, obtém-se o resultado mostrado na Tabela 17.

Tabela 17. Análise da significância do padrão sazonal do prêmio utilizando-se variáveis binárias.

\begin{tabular}{lccc}
\hline Variável & Coeficiente & Estatística t & Significância \\
\hline Constante & 0,418888889 & 3,25155 & 0,00162774 \\
BI $\{1\}$ & 0,128888889 & 0,70744 & 0,48116049 \\
BI $\{2\}$ & $-0,062222222$ & $-0,34152$ & 0,73352311 \\
BI $\{3\}$ & $-0,162222222$ & $-0,89040$ & 0,37567763 \\
BI $\{4\}$ & $-0,523888889$ & $-2,78966$ & 0,00646765 \\
BI $\{5\}$ & $-0,567638889$ & $-3,02262$ & 0,00328213 \\
BI $\{6\}$ & $-0,441388889$ & $-2,35035$ & 0,02099148 \\
BI $\{7\}$ & 0,068611111 & 0,36535 & 0,71572876 \\
BI $\{8\}$ & 0,291111111 & 1,55014 & 0,12469746 \\
BI $\{9\}$ & 0,292361111 & 1,55679 & 0,12310863 \\
BI $\{10\}$ & 0,028611111 & 0,15235 & 0,87925859 \\
BI $\{11\}$ & 0,116111111 & 0,61828 & 0,53798761 \\
\hline
\end{tabular}

Fonte: Dados da pesquisa

Na Tabela 17 a constante representa o mês base, isto é, dezembro. BI $\{1\}$ representa janeiro, BI $\{2\}$ fevereiro, etc. Ao nível de 5\%, BI $\{4\}$, BI $\{5\}$ e BI $\{6\}$, isto é, abril, maio e junho, são significativos. Isto implica que estes meses são estatisticamente diferentes do mês base (dezembro). Os coeficientes negativos observados em BI \{4\}, BI $\{5\}$ e BI $\{6\}$, mostram que o padrão sazonal mostrado na Figura 5 é estatisticamente significativo. Deve-se ressaltar que o padrão sazonal encontrado se refere aos prêmios negociados para os embarques mais próximos (mercado spot).

De fato, o prêmio possui um caráter altamente sazonal, o que está em harmonia com o comportamento dos preços internos e com as expectativas dos agentes do mercado. Contudo, as entrevistas mostraram que uma parcela da exportação tem seu volume e valor fixados em períodos de até um ano antes do período de embarque. Alguns trabalhos analisando a relação dos preços internacionais e domésticos utilizam o 
prêmio para o embarque mais próximo para compor o preço pago ao exportador (FOB) e daí relaciona-lo com o preço nas regiões de produção. $O$ fato de que parte dos embarques teve seu preço negociado meses antes justifica a capacidade menor que a esperada dos modelos em explicar as variações nos preços internos a partir de preços internacionais. Espera-se que ao determinar o período que o prêmio foi negociado, o grau de ajustamento dos modelos relacionando os mercados internacional e doméstico seja maior. A relação entre os valores de prêmio negociados antecipadamente e os preços observados no mercado interno constitui-se em tema importante para pesquisas futuras

\subsubsection{Importância relativa do prêmio}

Os gráficos 14 a 17 mostram quanto o prêmio altera o preço recebido pelo exportador (FOB porto). O preço FOB é resultado da soma das cotações da CBOT com o prêmio. Caso não houvesse o prêmio, o preço recebido pelo exportador seria igual às cotações da bolsa de Chicago. Ao adicionar o prêmio na composição do preço FOB, se o prêmio for diferente de zero, o valor FOB será maior ou menor que o valor anterior, caso o prêmio seja positivo ou negativo, respectivamente. Para cada uma das quatro séries montadas, foi considerado o preço FOB igual à cotação da CBOT para cada série, e posteriormente calculando-se quanto o prêmio altera o preço $\mathrm{FOB}$, tanto aumentando seu valor quanto o reduzindo.

A influência do prêmio sobre o preço FOB é tanto maior quanto maior seu valor absoluto. Para todas as séries, o prêmio reduz o preço FOB nos meses de embarque, com exceção dos anos de 1995 e 1996, quando o prêmio mantém o valor FOB acima das cotações na bolsa americana durante quase todo o período. A variação percentual do preço FOB devido ao prêmio é mostrada nas figuras 14 a 17. 


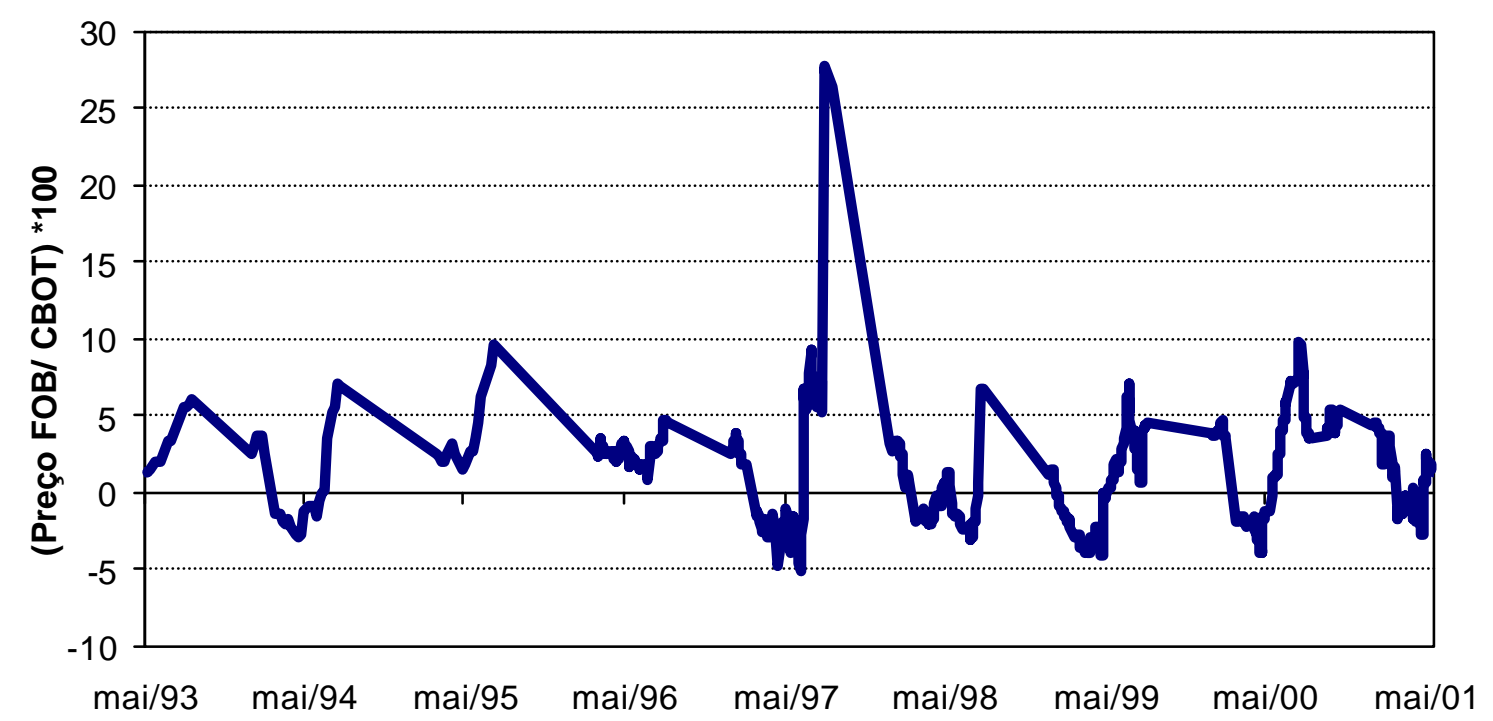

Figura 14 - Variação percentual do preço FOB devido ao prêmio para série 1.

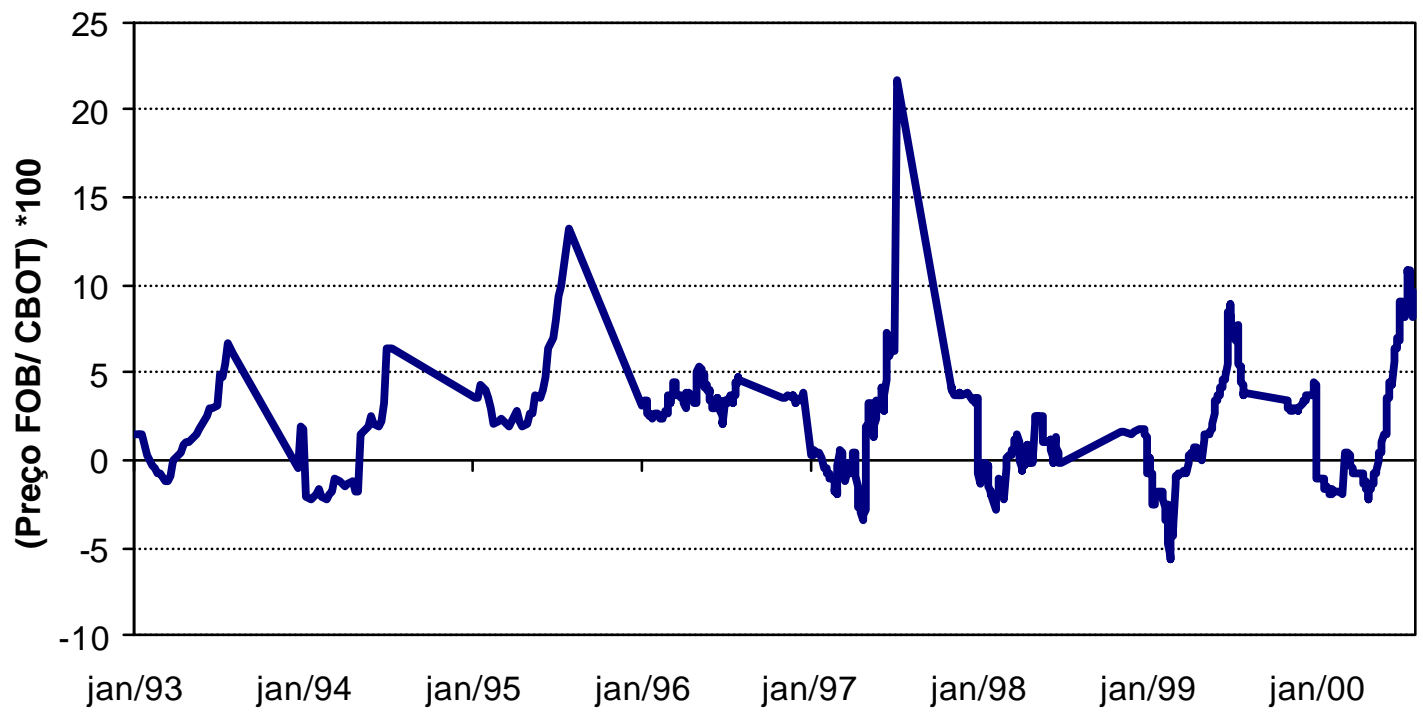

Figura 15 - Variação percentual do preço FOB devido ao prêmio para série 2. 


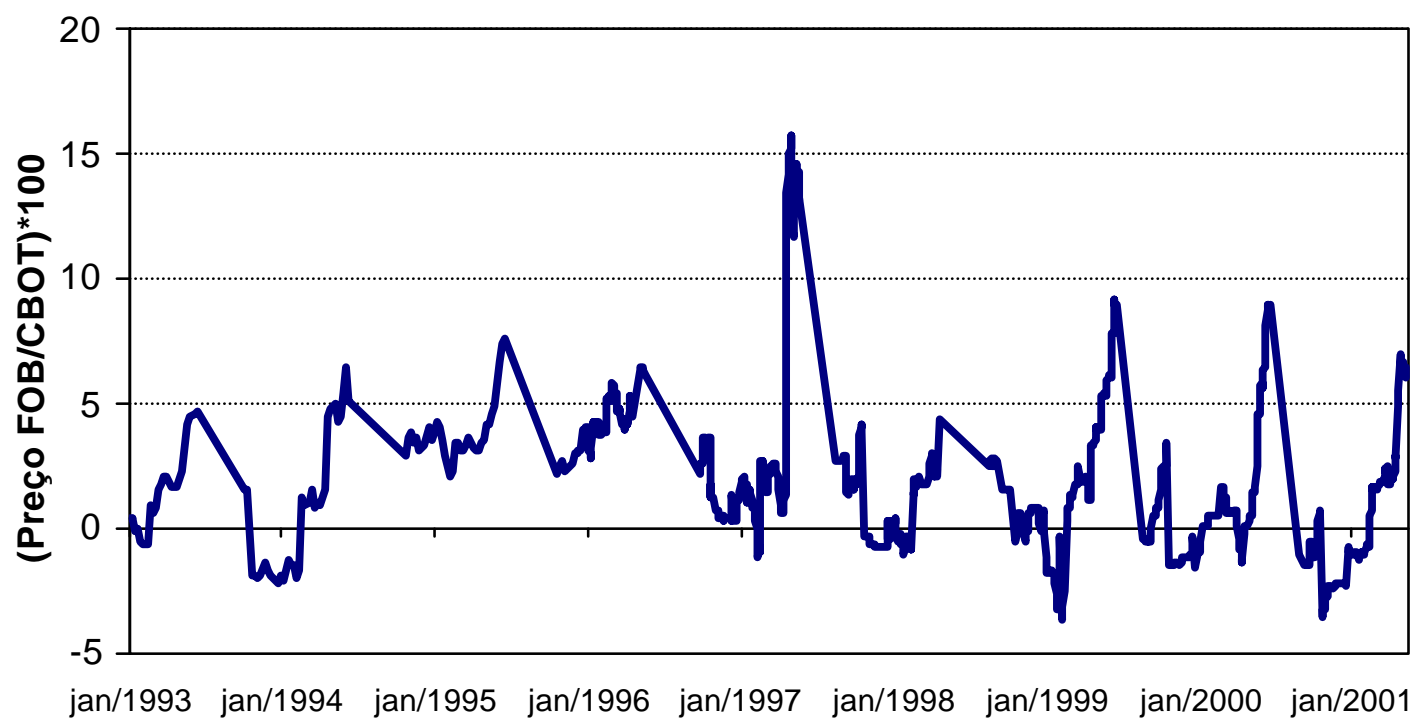

Figura 16 - Variação percentual do preço FOB devido ao prêmio para série 3.

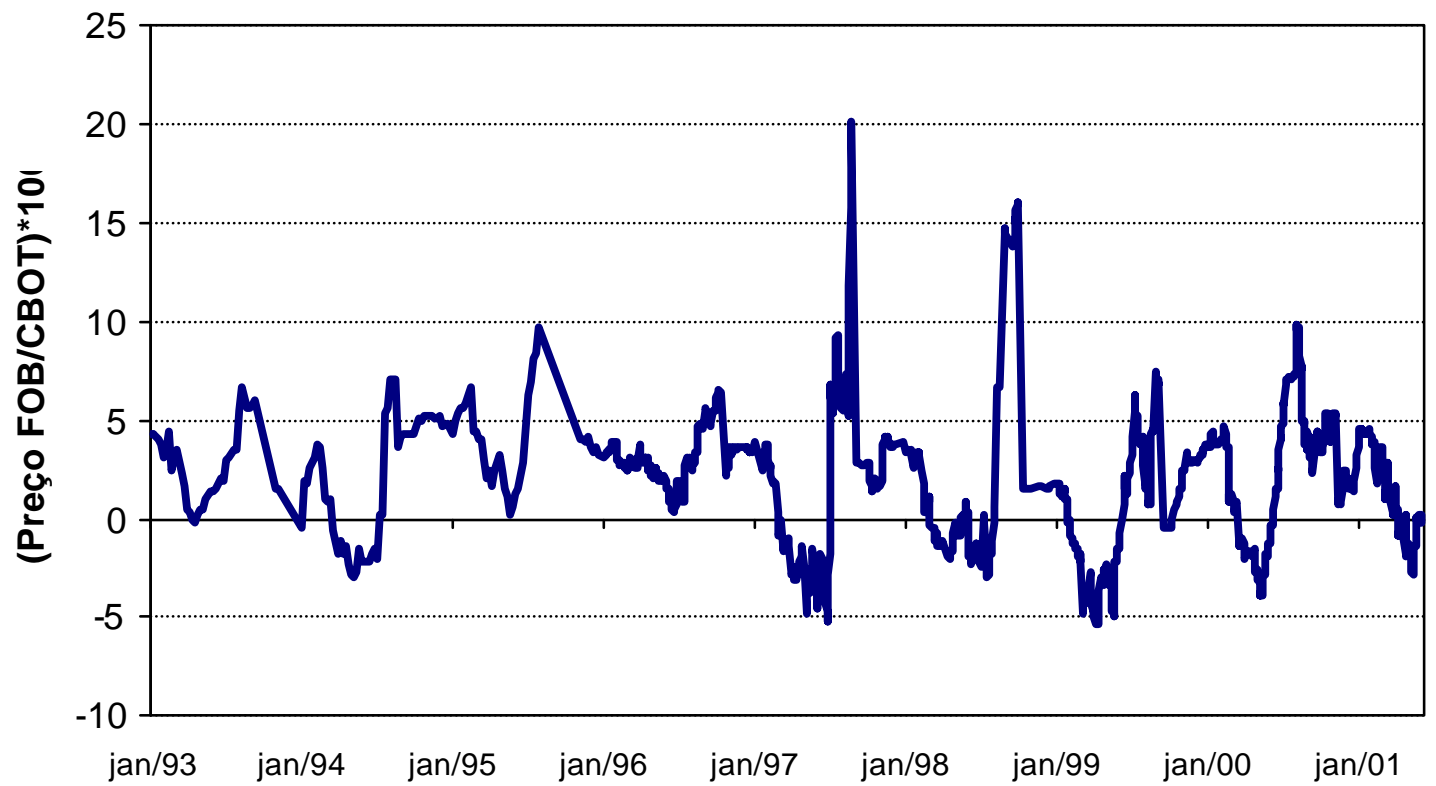

Figura 17 - Variação percentual do preço FOB devido ao prêmio para série 4. 


\subsubsection{Comportamento do prêmio para os principais meses de embarque da soja brasileira}

Embora o Brasil exporte soja praticamente o ano todo, os meses seguintes à colheita são os principais no ritmo de embarque, conforme observado na Figura 18. Assim, já era de se esperar que os principais meses de negociação do prêmio fossem abril, maio, junho, julho e agosto.

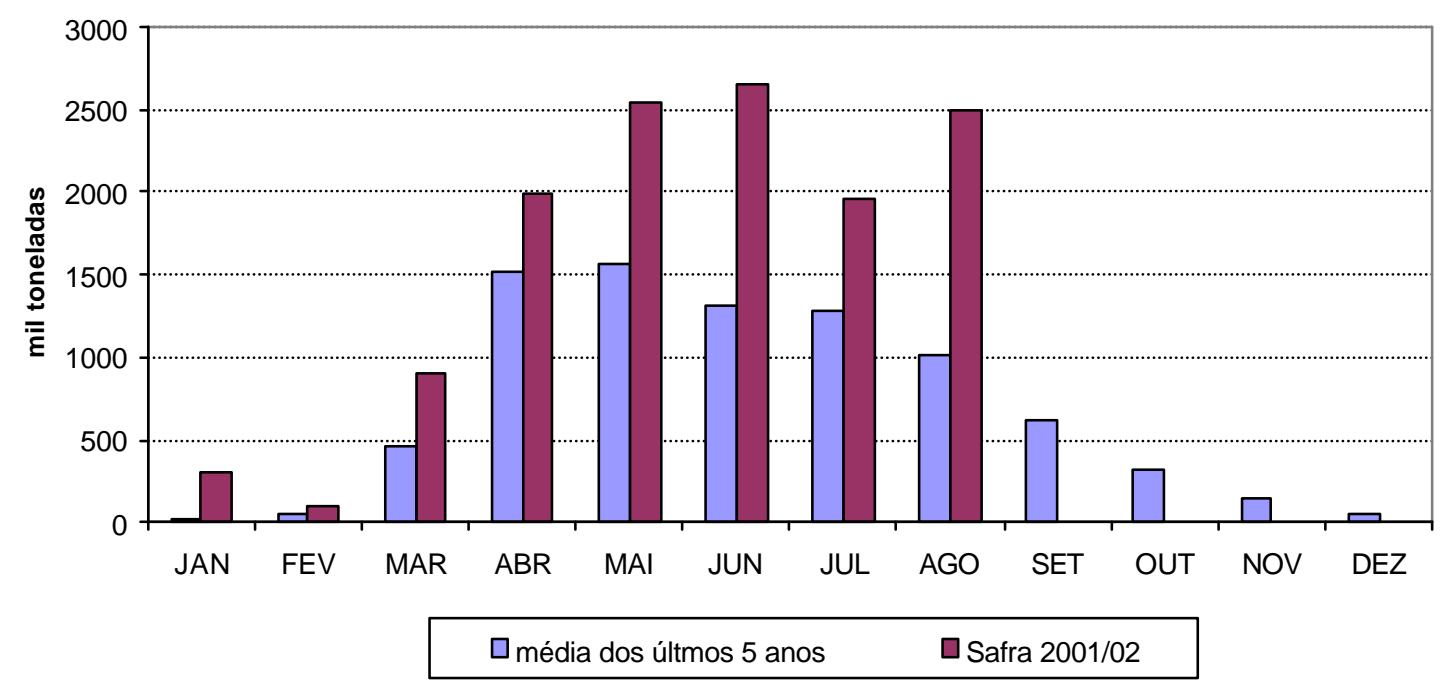

Figura 18 - Volume de soja embarcado em mil toneladas.

Fonte: Brasil (2002)

O comportamento do prêmio ao longo do ano para os meses acima citados pode ser visto nas figuras 19 a 23. 


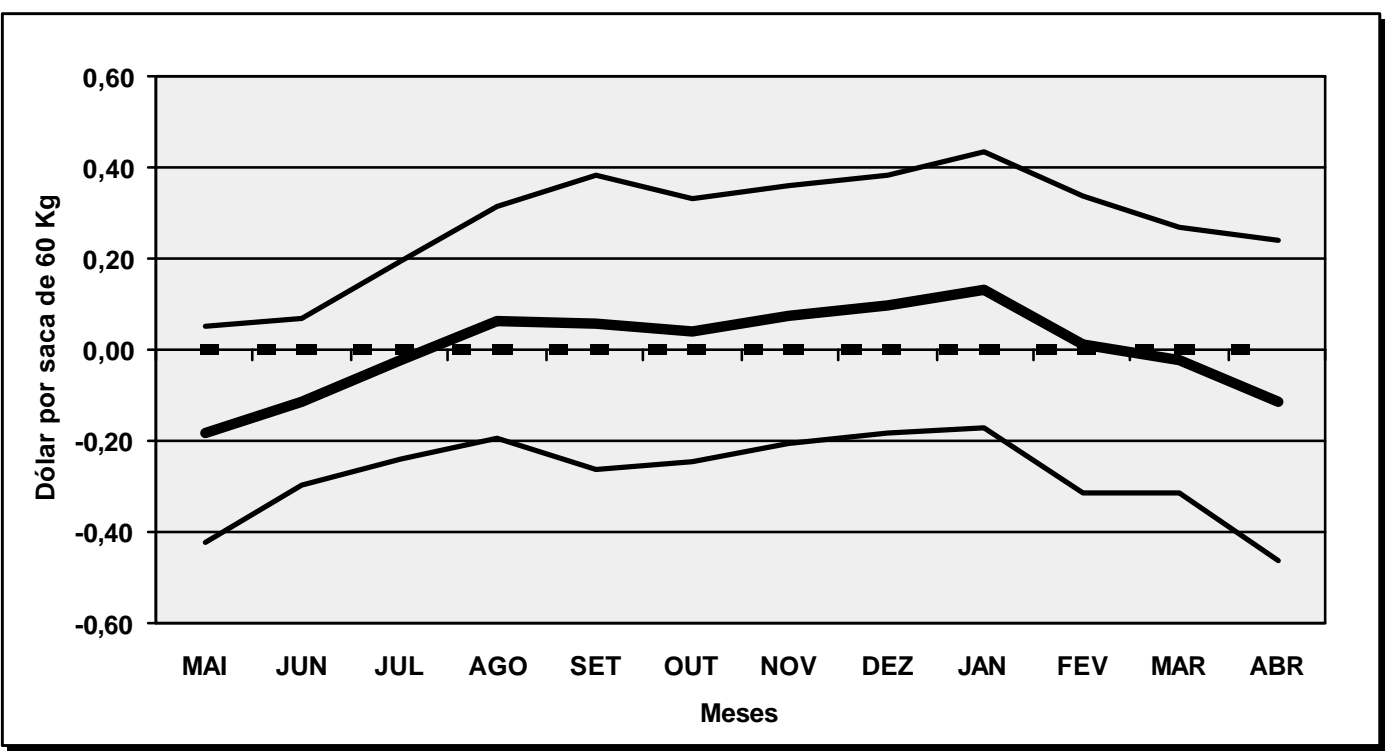

Figura 19 - Média mensal e desvio padrão do prêmio de exportação da soja em grão pelo porto de Paranaguá, de 1993 a 2002, para embarque em abril.

Fonte: Dados da pesquisa

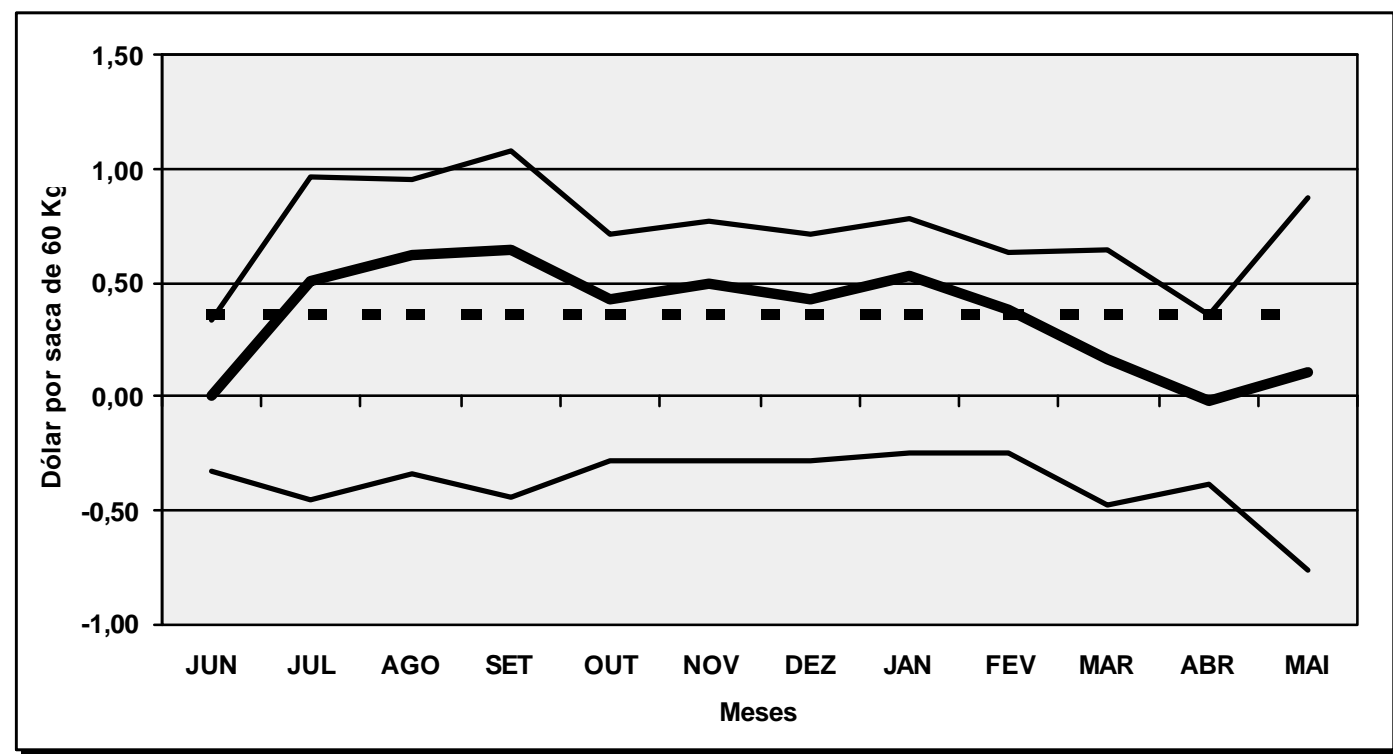

Figura 20 - Média mensal e desvio padrão do prêmio de exportação da soja em grão pelo porto de Paranaguá, de 1993 a 2002, para embarque em maio.

Fonte: Dados da pesquisa 


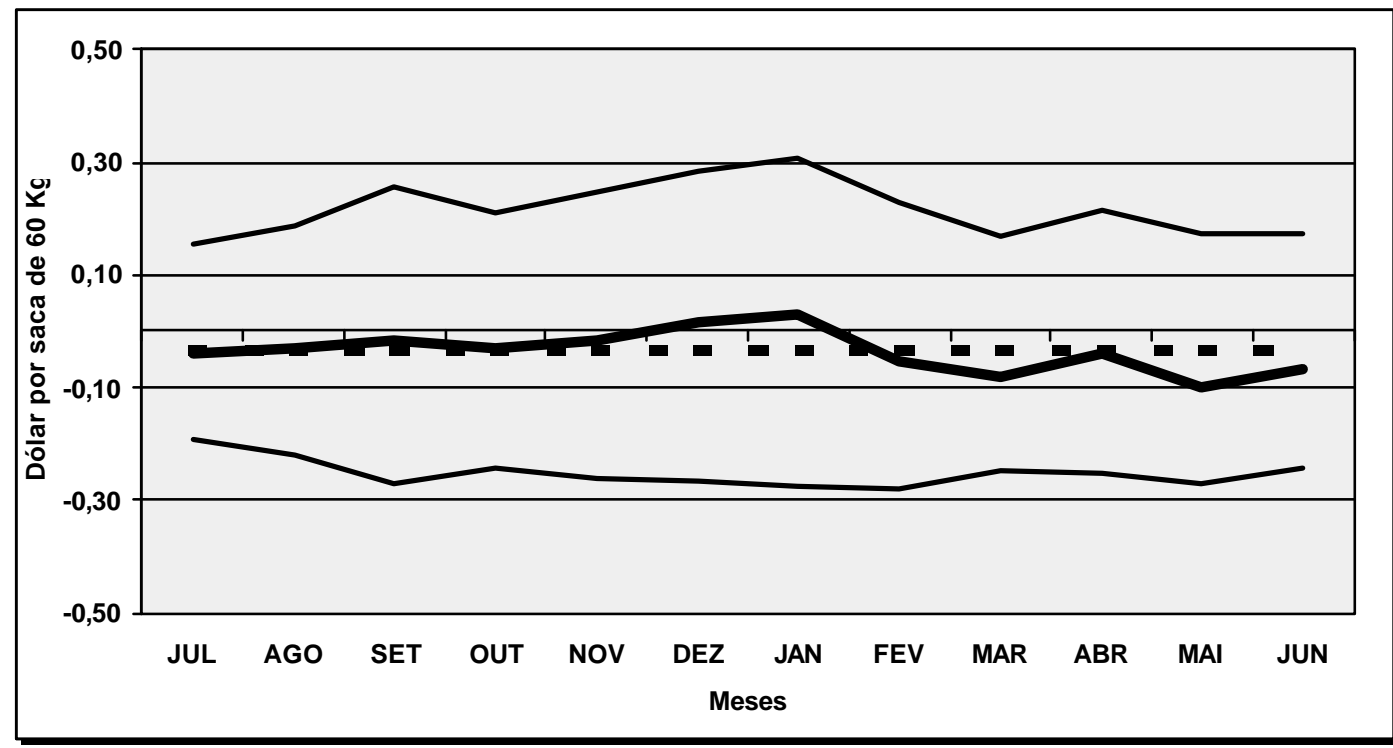

Figura 21 - Média mensal e desvio padrão do prêmio de exportação da soja em grão pelo porto de Paranaguá, de 1993 a 2002, para embarque em junho.

Fonte: Dados da pesquisa

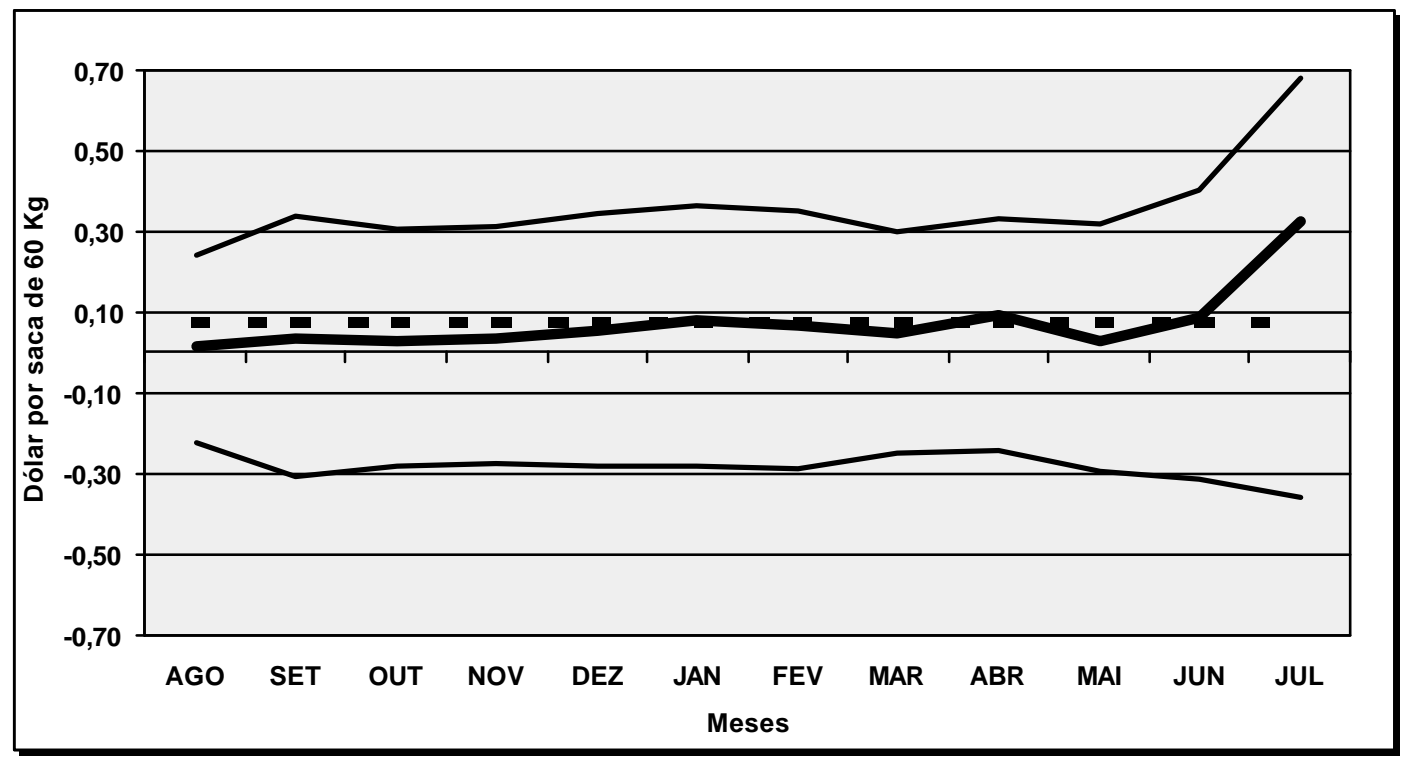

Figura 22 - Média mensal e desvio padrão do prêmio de exportação da soja em grão pelo porto de Paranaguá, de 1993 a 2002, para embarque em julho.

Fonte: Dados da pesquisa 


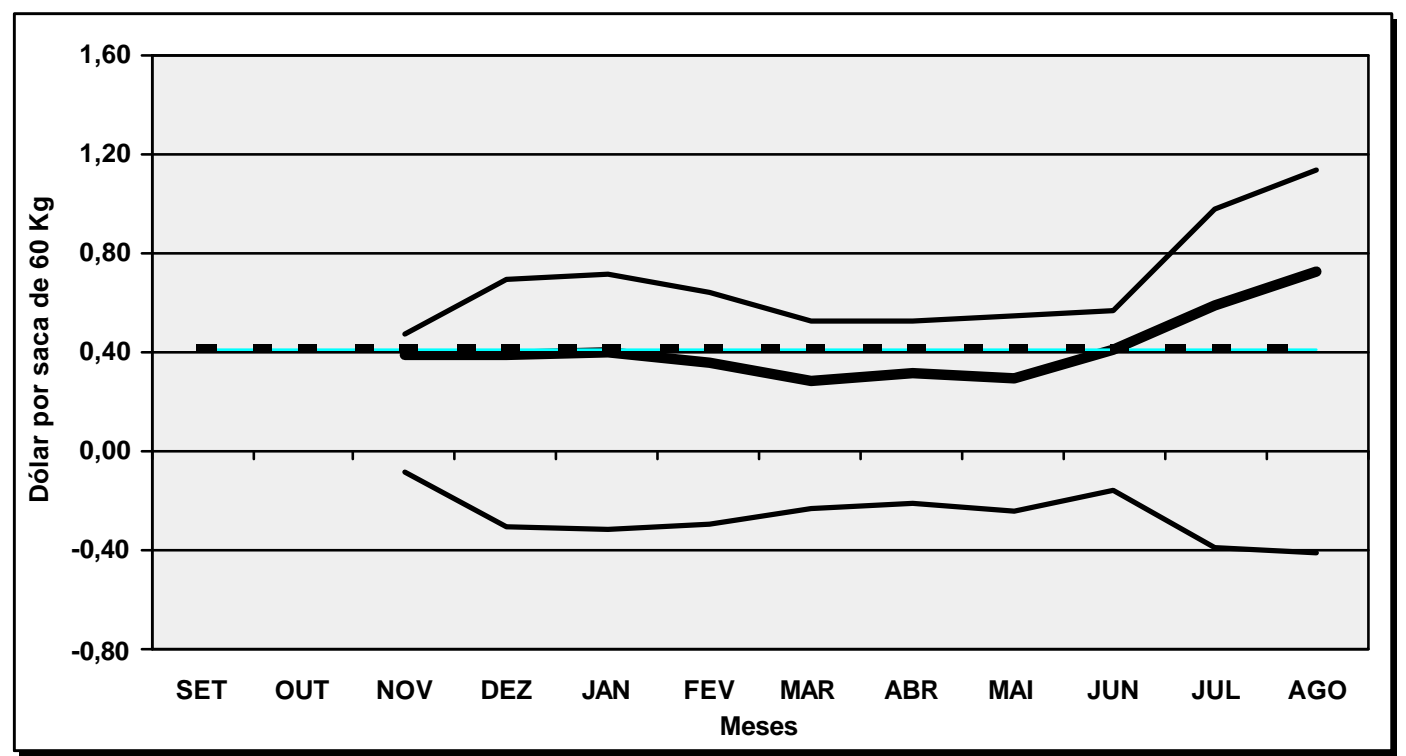

Figura 23 - Média mensal e desvio padrão do prêmio de exportação da soja em grão pelo porto de Paranaguá, de 1993 a 2002, para embarque em agosto.

Fonte: Dados da pesquisa

\subsection{Modelo teórico na determinação do prêmio}

As variáveis que determinam o prêmio de exportação da soja definidas na literatura, somada às determinadas através de entrevistas junto aos agentes do mercado, compõem o modelo teórico que será utilizado para explicar as variações no prêmio no porto de Paranaguá. A Tabela 18 mostra as variáveis para as quais foram levantadas séries estatísticas. Para algumas delas foram utilizadas proxies. 
Tabela 18. Variáveis importantes na determinação do prêmio de exportação da soja em grão pelo porto de Paranaguá, Paraná.

\begin{tabular}{ll}
\hline \multicolumn{1}{c}{ Variáveis } & \multicolumn{1}{c}{ Variáveis explicativas } \\
\hline Excedente de soja no mercado interno & Estoque mensal de soja no Brasil \\
Excedente de soja no mercado externo & Estoque mensal de soja na Argentina e EUA \\
Eficiência do porto exportador & Dias de chuva no porto (Antonina) \\
País de destino & Volume mensal exportado para a Ásia e para a \\
& Europa através do porto de Paranaguá \\
Preços dos derivados & $\begin{array}{l}\text { Preços do óleo de soja em São Paulo, com 12\% } \\
\text { de ICMS, em dólar; Preços do Farelo de Soja na }\end{array}$ \\
Taxa de Câmbio & região norte do Paraná, em dólar. (dados diários) \\
Disponibilidade de soja no porto de Paranaguá & Taxa de câmbio comercial venda (dados diários) \\
Frete Marítimo & Estoque diário de soja no porto de Paranaguá \\
Alternativas de comercialização externas & Preço Internacional do petróleo \\
\hline
\end{tabular}

\subsection{Testes de Raiz Unitária}

Para testar a presença de raiz unitária considerou o modelo autoregressivo de ordem $1\{\mathrm{AR}(1)\}$ para a variável prêmio, de ordem $10\{\mathrm{AR}(10)\}$ para o dólar, de ordem 20 para o preço do farelo $\{\mathrm{AR}(20)\}$, de ordem $19\{\mathrm{AR}(19)\}$ para o óleo e considerou-se a variável dias de chuva como modelo sem autoregressão. Para proceder ao teste foi considerado o seguinte modelo:

$$
\Delta y_{t}=a_{0}+\gamma y_{t-1}+a_{2} t+\sum \beta_{i} \Delta y_{t-i}+\varepsilon_{t}
$$

com,

$\alpha=$ Constante, $\mathrm{t}=$ Variável tendência,

$\mathrm{y}_{\mathrm{t}-1}=$ variável defasada $\mathrm{e}$

$\Delta \mathrm{y}_{\mathrm{t}-\mathrm{p}}=$ variáveis na diferença, sendo $\mathrm{p}$ definido pelo critério geral para específico, isto é, partindo-se de um número grande de defasagens, diminui-se até que a ultima 
defasagem torne-se significativa. Os resultados dos testes estão sumarizados nas tabelas 19 e 20.

Tabela 19. Testes de raiz unitária para as séries com dados diários: prêmio (PREMIO); dias de chuva (CHUVA); taxa cambial (DOLAR); preço interno em dólar do farelo (FARELO); preço interno em dólar do óleo (OLEO); prêmio do farelo (PFARELO); prêmio do óleo (POLEO), cotações do primeiro vencimento da Bolsa de Chicago (CBOT) e cotação do petróleo tipo Brent (PETRO), em nível e na diferença, quando necessário.

\begin{tabular}{lcccccc}
\hline Variável & $\tau_{\tau}$ & $\tau_{\beta \tau}$ & $\tau_{\mu}$ & $\tau_{\alpha \mu}$ & $\tau$ & Defasagens \\
\hline PREMIO & $-3,94^{* *}$ & --- & --- & --- & --- & $1 *$ \\
CHUVA & $-14,80^{*}$ & --- & --- & --- & --- & 0 \\
DOLAR & $-2,71$ & 2,61 & $-0,73$ & 1,17 & 1,24 & 13 \\
DDOLAR & $-9,45^{*}$ & --- & --- & --- & --- & 12 \\
FARELO & $-2,32$ & 1,19 & $-2,07$ & 2,06 & $-0,22$ & 12 \\
DFARELO & $-6,89^{*}$ & --- & --- & --- & --- & 11 \\
OLEO & $-2,17$ & $-0,38$ & $-2,31$ & 2,19 & $-0,97$ & $19^{*}$ \\
DOLEO & $-6,22^{*}$ & --- & --- & --- & --- & $18^{*}$ \\
PFARELO & $-4,45^{*}$ & --- & --- & --- & --- & $1 *$ \\
POLEO & $-1,71$ & $-0,74$ & $-1,56$ & $-0,68$ & $-1,43$ & $3^{*}$ \\
DPOLEO & $-22,39^{*}$ & --- & --- & --- & --- & $2 *$ \\
CBOT & $-2,31$ & $-1,96$ & $-1,22$ & 1,00 & $-1,08$ & $12^{* *}$ \\
DCBOT & $-10,22^{*}$ & --- & --- & --- & --- & $11^{* * *}$ \\
PETRO & $-1,08$ & 0,46 & $-1,98$ & 1,90 & $-0,75$ & 1 \\
DPETRO & $-9,06^{*}$ & --- & --- & --- & --- & 1 \\
\hline
\end{tabular}

Fonte: Dados da pesquisa

* Significativo ao nível de $1 \%$

** Significativo ao nível de 5\%

*** Significativo ao nível de $10 \%$ 
Tabela 20. Testes de raiz unitária para as variáveis com dados mensais: prêmio (PREMIO); precipitação mensal (CHUVA); taxa de câmbio (DOLAR); preço interno em dólar do farelo (FARELO); preço interno em dólar do óleo (OLEO); prêmio do farelo (PFARELO); prêmio do óleo (POLEO); estoque mensal no Brasil (EBRA); estoque mensal na Argentina $(E A R G)$; estoque mensal nos Estados Unidos (EEUA); exportações brasileiras $(E X B R A)$; exportações argentinas $(E X A R)$, cotações do primeiro vencimento da Bolsa de Chicago (CBOT) e cotação do petróleo tipo Brent (PETRO), em nível e na diferença, quando necessário.

\begin{tabular}{lcccccc}
\hline Variável & $\tau_{\tau}$ & $\tau_{\beta \tau}$ & $\tau_{\mu}$ & $\tau_{\alpha \mu}$ & $\tau$ & Defasagens \\
\hline PREMIO & $-4,48^{*}$ & --- & --- & --- & --- & $1^{* * *}$ \\
CHUVA & $-6,86^{*}$ & --- & --- & --- & --- & $6^{* *}$ \\
DOLAR & $-4,96^{*}$ & --- & --- & --- & --- & $11^{*}$ \\
FARELO & $-2,35$ & 2,28 & $-2,21$ & 2,15 & 0,53 & $1^{*}$ \\
DFARELO & $-6,69^{*}$ & --- & --- & --- & --- & 1 \\
OLEO & $-2,48$ & $-2,01$ & $-1,66$ & 1,62 & $-0,36$ & $3^{* *}$ \\
DOLEO & $-5,23^{*}$ & --- & --- & --- & --- & $2^{* * *}$ \\
PFARELO & $-6,94^{*}$ & --- & --- & --- & --- & $3^{*}$ \\
POLEO & $-2,86$ & $-0,27$ & $-2,91 * *$ & $-0,38$ & $-2,90^{*}$ & $1 *$ \\
EBRA & $-2,82$ & 1,5 & $-2,66$ & 2,65 & $-0,22$ & $12^{*}$ \\
DEBRA & $-2,68$ & $-1,16$ & $-2,53$ & 0,15 & $-2,59 * *$ & 11 \\
EARG & $-3,18$ & 2,77 & $-1,55$ & 1,66 & 0,18 & $12^{*}$ \\
DEARG & $-2,88$ & 0,41 & $-2,89$ & 0,62 & $-2,83 *$ & $11^{*}$ \\
EEUA & $-1,87$ & 1,77 & $-1,18$ & 1,17 & $-0,16$ & $12^{*}$ \\
DEEUA & $-5,04 *$ & --- & --- & --- & --- & 11 \\
EXBRA & $-2,21$ & 1,18 & $-2,39$ & 2,54 & 0,51 & 12 \\
DEXBRA & $-5,55^{*}$ & --- & --- & --- & --- & 11 \\
EXARG & $-1,55$ & 1,64 & $-0,70$ & 1,01 & 0,46 & $12^{*}$ \\
DEXARG & $-4,70^{*}$ & --- & --- & --- & --- & $11^{* *}$ \\
CBOT & $-1,92$ & $-1,44$ & $-1,28$ & 1,14 & $-0,89$ & $8 * * *$ \\
DCBOT & $-3,10$ & $-0,23$ & $-3,14 * *$ & $-0,68$ & $-3,08^{*}$ & 7 \\
PETRO & $-2,87$ & 1,66 & $-2,32$ & 2,39 & 0,052 & $10^{* *}$ \\
DPETRO & $-2,45$ & $-0,17$ & $-2,48$ & 0,56 & $-2,44 * *$ & $9 * * *$ \\
\hline
\end{tabular}

Fonte: Dados da pesquisa

* Significativo ao nível de $1 \%$

** Significativo ao nível de 5\%

*** Significativo ao nível de $10 \%$ 


\subsection{Regressão linear múltipla ${ }^{6}$}

\subsubsection{Dados diários}

A regressão utilizando as séries diárias tem por objetivo verificar se estas variáveis podem captar as variações diárias do prêmio (em dólar por saca de 60 quilos). As variáveis para as quais se pode obter informações diárias são:

1. Dias de chuva

2. Câmbio

3. Preço interno do farelo, em dólar por tonelada;

4. Preço interno do óleo, em dólar por tonelada;

5. Prêmio de exportação do farelo, em dólar por tonelada curta;

6. Prêmio de exportação do óleo, em centavos de dólar por libra-peso;

7. Cotação internacional do petróleo tipo Brent, em dólar por barril;

Embora algumas destas variáveis sejam significativas para explicar as variações diárias do prêmio, este modelo apresentou problemas de especificação, o que poderia ser indicado pela significância do teste $\mathrm{Q}$, o que indicaria a existência de outras variáveis, não incluídas no modelo, responsáveis por parte significativa das variações do prêmio diário. Uma importante variável é a disponibilidade de produto. No modelo utilizando variáveis mensais, os estoques no Brasil, Argentina e Estados Unidos foram utilizados como proxies da disponibilidade interna e externa de soja, eliminando o problema. Nas variáveis diárias, foi utilizada uma série diária de estoque de soja em grão no porto de Paranaguá. A limitação deste modelo consiste no fato de que a série estar disponível apenas para o período de maio de 2001 a março de 2002, totalizando 163 observações

\footnotetext{
6 Este estudo utilizou a metodologia da regressão linear múltipla apresentada por Hoffman (1998).
} 
para cada série. Adicionalmente, foi realizado o teste de Raiz Unitária para a série de estoque de soja no porto de Paranaguá (EPAGUA), sendo necessária uma diferença para tornar a série estacionária. Respeitando-se os testes de Raiz Unitária, foram realizados os testes de causalidade, cujos resultados estão sumarizados na Tabela 21.

Tabela 21. Relações causais entre o prêmio e suas variáveis determinantes utilizando-se dados diários.

\begin{tabular}{|c|c|c|c|c|}
\hline De & Para & Contemporânea & $\begin{array}{c}\text { Defasagens } \\
\text { Significativas }\end{array}$ & Teste F \\
\hline $\begin{array}{l}\text { Variação do prêmio do } \\
\text { óleo (DPOLEO) }\end{array}$ & $\begin{array}{l}\text { Premio do Grão } \\
\text { (PGRAO) }\end{array}$ & $-0,112142869$ & $\begin{array}{c}1 \operatorname{dia}\left(-0,242708416^{*}\right) \\
4 \operatorname{dias}\left(0,297034140^{*}\right) \\
8 \operatorname{dias}\left(-0,0,310743106^{*}\right) \\
9 \operatorname{dias}\left(-0,346977716^{*}\right) \\
11 \operatorname{dias}\left(0,152957561^{* * *}\right) \\
12 \operatorname{dias}\left(-0,215149999^{* *}\right)\end{array}$ & $6,979 *$ \\
\hline $\begin{array}{l}\text { Prêmio do farelo } \\
\text { (PFARELO) }\end{array}$ & $\begin{array}{l}\text { Premio do Grão } \\
\text { (PGRAO) }\end{array}$ & 0,007163765 & $\begin{array}{l}5 \operatorname{dias}\left(0,029504448^{*}\right) \\
8 \operatorname{dias}\left(-0,039504081^{*}\right) \\
11 \operatorname{dias}\left(0,025429770^{*}\right)\end{array}$ & $4,443^{*}$ \\
\hline $\begin{array}{l}\text { Variação do preço } \\
\text { interno do farelo } \\
\text { (DFARELO) }\end{array}$ & $\begin{array}{l}\text { Premio do Grão } \\
\text { (PGRAO) }\end{array}$ & $0,007660748^{* *}$ & $\begin{array}{c}1 \operatorname{dia}(-0,005626629 * * *) \\
2 \operatorname{dias}(-0,009500252 *) \\
3 \operatorname{dias}(-0,009024429 *) \\
5 \operatorname{dias}(-0,005532387 * *) \\
7 \operatorname{dias}(-0,006957919 * *) \\
8 \operatorname{dias}(-0,008185644 * *) \\
9 \operatorname{dias}(-0,009056377 *) \\
11 \operatorname{dias}(-0,007147293 * *)\end{array}$ & $4,181 *$ \\
\hline $\begin{array}{l}\text { Variação do preço } \\
\text { interno do óleo } \\
\text { (DOLEO) }\end{array}$ & $\begin{array}{l}\text { Premio do Grão } \\
\text { (PGRAO) }\end{array}$ & $0,004152642 * *$ & $2 \operatorname{dias}(-0,003245639) * * *$ & 1,517 \\
\hline $\begin{array}{l}\text { Dias de chuva } \\
\text { (CHUVA) }\end{array}$ & $\begin{array}{l}\text { Premio do Grão } \\
\text { (PGRAO) }\end{array}$ & 0,000589124 & $\begin{array}{c}2 \operatorname{dias}(-0,013404199 * *) \\
3 \operatorname{dias}(0,020930509 *) \\
8 \operatorname{dias}(-0,008664997 * * *)\end{array}$ & $3,493 *$ \\
\hline $\begin{array}{c}\text { Variação da taxa } \\
\text { cambial (DDOLAR) }\end{array}$ & $\begin{array}{l}\text { Premio do Grão } \\
\text { (PGRAO) }\end{array}$ & $-0,435287519$ & - & 0,389 \\
\hline $\begin{array}{c}\text { Variação da cotação na } \\
\text { bolsa de Chicago } \\
\text { (DCBOT) }\end{array}$ & $\begin{array}{l}\text { Premio do Grão } \\
\quad \text { (PGRAO) }\end{array}$ & 0,2000431263 & - & 1,466 \\
\hline $\begin{array}{c}\text { Variação do estoque no } \\
\text { porto de Paranaguá } \\
\text { (DEPAGUA) }\end{array}$ & $\begin{array}{l}\text { Premio do Grão } \\
\text { (PGRAO) }\end{array}$ & 0,490204037 & $\begin{array}{c}2 \operatorname{dias}(1,847763134 *) \\
5 \operatorname{dias}(2,161946414 *) \\
8 \operatorname{dias}\left(1,323174747^{* *}\right)\end{array}$ & $3,541 *$ \\
\hline $\begin{array}{l}\text { Cotação internacional } \\
\text { do petróleo (PETRO) }\end{array}$ & $\begin{array}{l}\text { Premio do Grão } \\
\text { (PGRAO) }\end{array}$ & $-0,002174574$ & $\begin{array}{l}2 \operatorname{dias}(0,031883846 * * *) \\
5 \operatorname{dias}\left(0,033597666^{* * *}\right)\end{array}$ & 1,856 \\
\hline
\end{tabular}


Tabela 21. Relações causais entre o prêmio e suas variáveis determinantes utilizando-se dados diários.

\begin{tabular}{|c|c|c|c|c|}
\hline De & Para & Contemporânea & $\begin{array}{l}\text { Defasagens } \\
\text { Significativas }\end{array}$ & Teste $\mathrm{F}$ \\
\hline $\begin{array}{l}\text { Premio do Grão } \\
\text { (PGRAO) }\end{array}$ & $\begin{array}{l}\text { Variação do } \\
\text { prêmio do óleo } \\
\text { (DPOLEO) }\end{array}$ & $-0,117208373$ & 1 dia $\left(0,2510001111^{* * *}\right)$ & 1,295 \\
\hline $\begin{array}{l}\text { Premio do Grão } \\
\text { (PGRAO) }\end{array}$ & $\begin{array}{l}\text { Prêmio do } \\
\text { farelo } \\
\text { (PFARELO) }\end{array}$ & 1,284480653 & $\begin{array}{l}1 \operatorname{dia}(2,521029460 * * *) \\
2 \operatorname{dias}\left(-3,964969500^{*}\right) \\
5 \operatorname{dias}(3,143650097 * *) \\
6 \operatorname{dias}\left(-3,509617169^{* *}\right)\end{array}$ & $4,153^{*}$ \\
\hline $\begin{array}{l}\text { Premio do Grão } \\
\text { (PGRAO) }\end{array}$ & $\begin{array}{l}\text { Variação do } \\
\text { preço interno } \\
\text { do óleo } \\
\text { (DOLEO) }\end{array}$ & $8,215250888^{* *}$ & $\begin{array}{c}2 \operatorname{dias}(-9,796140985 * * *) \\
6 \operatorname{dias}(-8,178152050 * *)\end{array}$ & 1,603 \\
\hline $\begin{array}{l}\text { Premio do Grão } \\
\text { (PGRAO) }\end{array}$ & $\begin{array}{l}\text { Variação do } \\
\text { preço interno } \\
\text { do farelo } \\
\text { (DFARELO) }\end{array}$ & $4,53930359 * *$ & $\begin{array}{c}1 \operatorname{dia}\left(-4,66290516^{* * *}\right) \\
5 \operatorname{dias}\left(10,90935831^{*}\right) \\
6 \operatorname{dias}\left(-5,69783573^{* *}\right) \\
7 \operatorname{dias}\left(-5,91582346^{* * *}\right) \\
9 \operatorname{dias}\left(6,38842736^{* *}\right) \\
10 \operatorname{dias}\left(-4,36196431^{* *}\right)\end{array}$ & $2,338 * *$ \\
\hline $\begin{array}{l}\text { Premio do Grão } \\
\text { (PGRAO) }\end{array}$ & $\begin{array}{c}\text { Variação da } \\
\text { taxa cambial } \\
\text { (DDOLAR) }\end{array}$ & $-0,008219552$ & 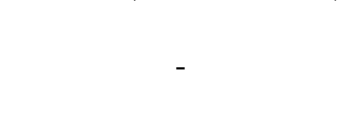 & 0,339 \\
\hline $\begin{array}{l}\text { Premio do Grão } \\
\text { (PGRAO) }\end{array}$ & $\begin{array}{l}\text { Variação da } \\
\text { cotação na } \\
\text { bolsa de } \\
\text { Chicago } \\
\text { (DCBOT) }\end{array}$ & 0,040885162 & 6 dias $(-0,143870543 *)$ & 0,359 \\
\hline $\begin{array}{l}\text { Premio do Grão } \\
\text { (PGRAO) }\end{array}$ & $\begin{array}{l}\text { Variação do } \\
\text { estoque no } \\
\text { porto de } \\
\text { Paranaguá } \\
\text { (DEPAGUA) }\end{array}$ & 0,008147153 & $\begin{array}{l}3 \text { dias }(0,053431100 *) \\
4 \operatorname{dias}(-0,025995682 *)\end{array}$ & $2,636 * *$ \\
\hline $\begin{array}{l}\text { Premio do Grão } \\
\text { (PGRAO) }\end{array}$ & $\begin{array}{c}\text { Cotação } \\
\text { internacional do } \\
\text { petróleo } \\
\text { (PETRO) } \\
\end{array}$ & $-0,275448565$ & - & 1,656 \\
\hline
\end{tabular}

Fonte: Dados da pesquisa

* significativo a $1 \%$

** significativo a $5 \%$

$* * *$ significativo a $10 \%$

As relações causais apresentadas na 21 podem ser resumidas na Figura 24. 


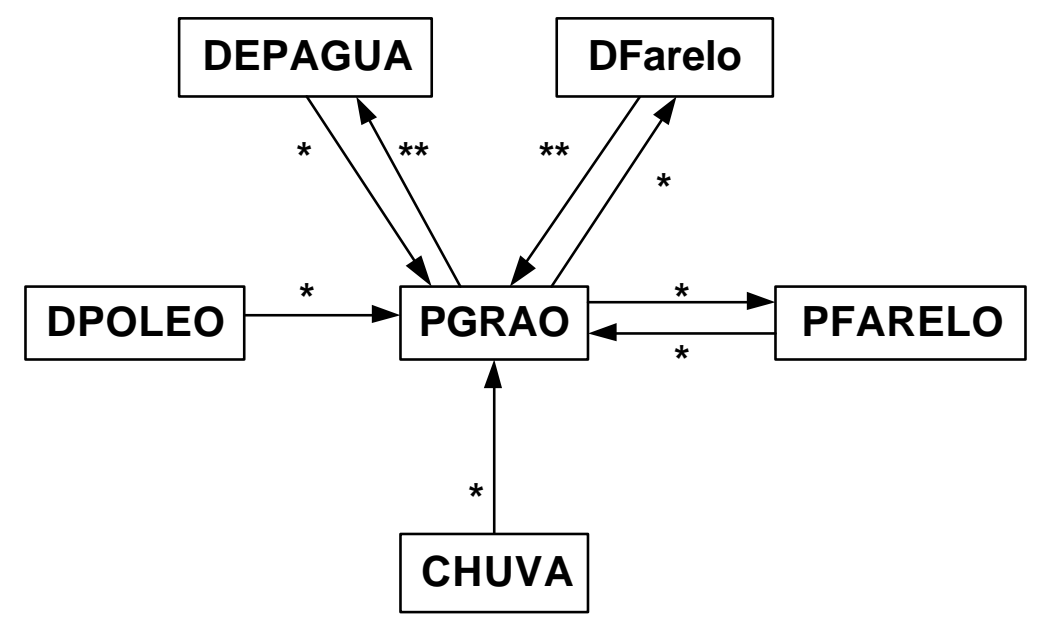

Figura 24 - Representação das relações causais entre as variáveis determinantes do prêmio de exportação da soja (dados diários).

* significativo a $1 \%$

** significativo a $5 \%$

A partir dos resultados dos testes de causalidade foi realizada uma regressão entre o prêmio do grão e as variáveis explicativas disponíveis nas séries diárias. As variáveis que apresentaram raiz unitária foram diferenciadas, para que todas aquelas utilizadas na regressão estivessem em nível. Caso contrário, segundo Gujarati (1995), os valores dos testes apresentados poderiam estar viesados. Considerando-se o período de maio de 2001 a março de 2002, tem-se a estimativa do prêmio diário, cujos resultados estão sumarizados nas tabelas 22 e 23 . Na Tabela 22 , o número de defasagens é o mesmo do número determinado no teste de causalidade. Na Tabela 23 estão os resultados da regressão utilizando-se 5 defasagens para cada variável. Adicionalmente, foi realizado o teste da soma dos coeficientes dada a forte alternância do sinal dos coeficientes, auxiliando na interpretação dos resultados.

Os coeficientes mostrados nas tabelas 22 e 23 não são elasticidades, como normalmente observado. Não foi possível obter as elasticidades pois o prêmio de exportação assume valores positivos e negativos, impossibilitando o cálculo do logaritmo dessas variáveis. Como os coeficientes não são elasticidades, a magnitude do 
coeficiente dependerá da unidade utilizada para medir as variáveis dependentes e explicativas. Assim, mudanças nas unidades podem alterar o valor do coeficiente mas não seu sinal. 
Tabela 22. Estimativa do prêmio em função das variáveis com dados diários, com o número de defasagens determinadas no teste de causalidade e teste da soma dos coeficientes.

\begin{tabular}{|c|c|c|c|c|c|c|c|c|c|c|c|c|c|c|}
\hline Regressor & $\mathrm{t}$ & $\mathrm{t}-1$ & $\mathrm{t}-2$ & $t-3$ & $t-4$ & $t-5$ & $\mathrm{t}-6$ & $t-7$ & $\mathrm{t}-8$ & $\mathrm{t}-9$ & $\mathrm{t}-10$ & $\mathrm{t}-11$ & $\mathrm{t}-12$ & $\begin{array}{c}\text { Soma } \\
\left(\mathrm{H}_{0}=0\right)\end{array}$ \\
\hline Constante & $0,1695^{*}$ & & & & & & & & & & & & & \\
\hline PGRAO & & $0,9205^{*}$ & $0,2645 * *$ & * 0,0286 & $-0,4859 *$ & $0,1839 * * *$ & & & & & & & & $1,0813044^{*}$ \\
\hline PFARELO & 0,0033 & $-0,0165$ & 0,0063 & $-0,0045$ & 0,0066 & 0,0081 & 0,0099 & 0,0010 & $-0,0240 * *$ & 0,0028 & $-0,0123$ & $0,0211^{*}$ & & 0,0019855 \\
\hline DFARELO & $0,0075^{* *}$ & $*-0,0030$ & $-0,0003$ & $-0,0024$ & 0,0041 & $-0,0001$ & $0,0075^{* * *}$ & $-0,0050$ & $-0,0010$ & $-0,0067 * *:$ & $-0,0004$ & $-0,0096^{*}$ & & $-0,0096659$ \\
\hline CHUVA & $-0,0009$ & $0,1245 * *$ & $-0,0166^{*}$ & $=0,0096$ & $-0,0083$ & $-0,0043$ & $-0,0087$ & 0,0017 & $-0,0154 *$ & & & & & $-0,0307256^{*}$ \\
\hline DEPAGUA & $-0,9910 * *$ & 0,9478 & $-0,3122$ & 0,2031 & 0,5296 & $0,9786 * * *$ & 0,5810 & $1,0870 * * *$ & & & & & & $3,024203 * * * / 1$ \\
\hline
\end{tabular}

Fonte: Dados da pesquisa

$\mathrm{R}^{2}=0,96$

$\mathrm{Q}(36)=33,63$

$\mathrm{F}(59,90)=64,87$

* significativo a $1 \%$

** significativo a $5 \%$

$* * *$ significativo a $10 \%$

/1 não difere estatisticamente

de 1 
Tabela 23. Estimativa do prêmio em função das variáveis com dados diários, com cinco defasagens e teste da soma dos coeficientes.

\begin{tabular}{lccccccc}
\hline Regressor & $\mathrm{t}$ & $\mathrm{t}-1$ & $\mathrm{t}-2$ & $\mathrm{t}-3$ & $\mathrm{t}-4$ & $\mathrm{t}-5$ & $\begin{array}{c}\text { Soma } \\
\left(\mathrm{H}_{0}=0\right)\end{array}$ \\
\hline Constante & 0,0456 & & & & & & \\
PGRAO & & $1,0084^{*}$ & $0,3463^{*}$ & $-0,3401^{*}$ & $-0,3053^{* *}$ & $0,2499^{*}$ & $0,9592^{*}$ \\
DPOLEO & 0,1258 & $-0,1060$ & 0,0655 & $-0,0129$ & $0,3158^{*}$ & 0,0450 & 0,3074 \\
PFARELO & $-0,0097$ & 0,0044 & 0,0058 & $-0,0080$ & $-0,0033$ & 0,0086 & 0,0075 \\
& & & & & & & \\
DFARELO & $0,0072^{* *}$ & $-0,0037$ & $-0,0063^{* * *}$ & $-0,0052$ & 0,0008 & $-0,0042$ & $-0,0186$ \\
CHUVA & $-0,0056$ & $0,0124^{* *}$ & $-0,0167^{*}$ & $0,0203^{*}$ & $-0,0022$ & $-0,0040$ & 0,0042 \\
DEPAGUA & $-0,0114$ & 0,5299 & 0,3088 & 0,0026 & 0,6615 & $1,2320^{* *}$ & $2,7348^{* 11}$ \\
\hline
\end{tabular}

Fonte: Dados da pesquisa

$\mathrm{R}^{2}=0,96$

$\mathrm{F}(59,90)=64,87$

$\mathrm{Q}(36)=33,63$

* significativo a $1 \%$

** significativo a $5 \%$

*** significativo a $10 \%$

$/ 1$ não difere estatisticamente de 1

Os resultados apresentados nos testes de causalidade, utilizando-se dados diários, conforme apresentados na Tabela 21 e exemplificados na Figura 24, mostram quais variáveis apresentam relação significativa com o prêmio de exportação do grão. As tabelas 22 e 23 mostram o resultado da regressão do prêmio com as variáveis que se mostram relevantes nos testes de causalidade. Os resultados demonstrados nas tabelas 22 e 23 mostram forte oscilação nos sinais das defasagens das variáveis explicativas. Desta forma, optou-se por analisar o sinal da soma dos coeficientes. Utilizando-se a Tabela 23, nota-se que: 
a) Elevação nos valores passados do prêmio do grão tendem a elevar seu valor atual. Como exemplo,

b) Aumento no prêmio do óleo de soja tendem a aumentar o prêmio do grão.

c) Elevação no prêmio do farelo de soja tendem a aumentar o prêmio do grão.

d) Incrementos no preço interno do farelo tendem a deprimir o prêmio do grão

e) Aumento no número de dias consecutivos com chuva tendem a elevar o prêmio do grão.

f) Aumento no estoque de soja no porto de paranaguá tende a aumentar o prêmio do grão.

Com relação ao número de dias de chuva, quando se considera 8 defasagens, conforme mostrado na Tabela 22, percebe-se que quanto maior o número de dias de chuva no porto, menor o prêmio pago em Paranaguá.

Estes resultados estão em concordância com as hipóteses básicas discutidas inicialmente, com exceção apenas para a relação entre o preço do farelo no mercado interno e o prêmio de exportação. Esperava-se que aumentos no preço interno do farelo resultassem em elevação do prêmio do grão, o que não se verificou, embora o teste da soma dos coeficientes não seja significativo. Resultados semelhantes foram obtidos utilizando-se dados mensais.

\subsubsection{Dados mensais}

A regressão utilizando as séries mensais tem por objetivo verificar se as séries disponíveis podem explicar as variações do prêmio (em dólar por saca de 60 quilos) utilizando um período de maior abrangência. As variáveis inicialmente testadas são:

1. Chuva, em milímetros; 
2. Câmbio;

3. Preço interno do farelo, em dólar por tonelada;

4. Preço interno do óleo, em dólar por tonelada;

5. Prêmio de exportação do farelo, em dólar por tonelada curta;

6. Prêmio de exportação do óleo, em dólar por libra-peso;

7. Estoque de soja no Brasil, em mil toneladas;

8. Estoque de soja na Argentina, em mil toneladas;

9. Estoque de soja nos Estados Unidos, em mil toneladas;

10. Percentual exportado para a Ásia do total exportado por Paranaguá;

11. Percentual exportado para a Europa do total exportado pelo porto de Paranaguá;

12. Média mensal da cotação do petróleo tipo Brent, em dólar por barril;

Não foram utilizadas as séries de exportação Argentina e brasileira, pois estas variáveis não são independentes do estoque nesses dois países. Foram realizados testes utilizando somente as exportações e outra com os estoques. Os resultados mostraram que a variável estoque é mais significativa em explicar as variações mensais do prêmio. Também não foi considerada a variável chuva pois, tanto o prêmio quanto o período de chuva, possuem um importante componente sazonal, o que explica a relação positiva e significativa encontrada entre as duas variáveis.

Para determinar quais variáveis seriam utilizadas, foram realizados testes de causalidade entre as variáveis disponíveis e o prêmio, chegando-se aos resultados sumarizados na Tabela 24. 
Tabela 24. Relações causais entre o prêmio e suas variáveis determinantes com dados mensais

\begin{tabular}{|c|c|c|c|c|}
\hline De & Para & Contemporânea & $\begin{array}{l}\text { Defasagens } \\
\text { Significativas }\end{array}$ & Teste F \\
\hline $\begin{array}{l}\text { Variação do Estoque no } \\
\text { Brasil (DEBRA) }\end{array}$ & $\begin{array}{l}\text { Prêmio do grão } \\
\text { (PGRAO) }\end{array}$ & $-0,000169272 *$ & $\begin{array}{l}10 \text { meses }(-0,00133007 *) \\
11 \text { meses }\left(0,000115907^{* *}\right)\end{array}$ & $1,725 * * *$ \\
\hline $\begin{array}{l}\text { Variação do Estoque nos } \\
\text { Estados Unidos (DEEUA) }\end{array}$ & $\begin{array}{l}\text { Prêmio do grão } \\
\text { (PGRAO) }\end{array}$ & $-6,9719 \mathrm{e}-06 * *$ & $\begin{array}{l}4 \text { meses }(-7,1644 \mathrm{e}-06 * *) \\
6 \text { meses }(-7,5734 \mathrm{e}-06 * *) \\
7 \text { meses }(-6,2086 \mathrm{e}-06 * *)\end{array}$ & $2,518 * *$ \\
\hline $\begin{array}{l}\text { Variação do Estoque na } \\
\text { Argentina (DEARG) }\end{array}$ & $\begin{array}{l}\text { Prêmio do grão } \\
\text { (PGRAO) }\end{array}$ & $-0,000064644 * * *$ & $\begin{array}{l}3 \text { meses }(0,000064953 * * *) \\
4 \text { meses }(-0,000076473 * *) \\
5 \text { meses }(0,000051702 * * *)\end{array}$ & $3,947 *$ \\
\hline Prêmio do óleo (POLEO) & $\begin{array}{l}\text { Prêmio do grão } \\
\text { (PGRAO) }\end{array}$ & $0,170139071^{* *}$ & $\begin{array}{c}1 \text { mês }(-0,202669829 * * *) \\
8 \text { meses }(0,098645287 * * *)\end{array}$ & 1,692 \\
\hline $\begin{array}{l}\text { Prêmio do Farelo } \\
\text { (PFARELO) }\end{array}$ & $\begin{array}{l}\text { Prêmio do grão } \\
\text { (PGRAO) }\end{array}$ & $0,015942646^{* *}$ & $\begin{array}{c}1 \text { mês }(-0,019931439 * *) \\
6 \text { meses }(-0,014183679 * * *) \\
7 \text { meses }(0,015045045 * *)\end{array}$ & $2,493 * *$ \\
\hline $\begin{array}{l}\text { Variação do Preço Interno } \\
\text { do Óleo (DOLEO) }\end{array}$ & $\begin{array}{l}\text { Prêmio do grão } \\
\text { (PGRAO) }\end{array}$ & $-0,000114642$ & $\begin{array}{c}6 \text { meses }\left(-0,004468666^{* *}\right) \\
7 \text { meses }(0,003691465 * * *) \\
9 \text { meses }(0,002953260 * *)\end{array}$ & 1,217 \\
\hline $\begin{array}{l}\text { Variação do Preço Interno } \\
\text { do Farelo (DFARELO) }\end{array}$ & $\begin{array}{l}\text { Prêmio do grão } \\
\text { (PGRAO) }\end{array}$ & 0,000169428 & 6 meses $(-0,007874302 *)$ & $2,427 * *$ \\
\hline $\begin{array}{l}\text { Percentual exportado para } \\
\text { Ásia através do porto de } \\
\text { Paranaguá (ASIA) }\end{array}$ & $\begin{array}{l}\text { Prêmio do grão } \\
\text { (PGRAO) }\end{array}$ & 0,001621514 & 7 meses $(-0,004466271 * * *)$ & $2,070 * * *$ \\
\hline $\begin{array}{l}\text { Percentual exportado para } \\
\text { Europa através do porto de } \\
\text { Paranaguá (EUROPA) }\end{array}$ & $\begin{array}{l}\text { Prêmio do grão } \\
\text { (PGRAO) }\end{array}$ & $-0,004617141$ & 1 mês $(0,014355250 *)$ & $2,379 * *$ \\
\hline $\begin{array}{l}\text { Cotação internacional } \\
\text { do petróleo (PETRO) }\end{array}$ & $\begin{array}{l}\text { Premio do Grão } \\
\text { (PGRAO) }\end{array}$ & $0,040730296 * * *$ & 8 meses $(-0,059530370 * *)$ & 1,633 \\
\hline Prêmio do grão (PGRAO) & $\begin{array}{l}\text { Prêmio do Farelo } \\
\text { (PFARELO) }\end{array}$ & $6,863883952 *$ & 6 meses $(-5,048115715 * * *)$ & $2,620 * *$ \\
\hline Prêmio do grão (PGRAO) & $\begin{array}{l}\text { Prêmio do Óleo } \\
\text { (POLEO) }\end{array}$ & $0,387822141 * * *$ & $\begin{array}{c}1 \text { mês }(-0,570759662 * *) \\
5 \text { meses }(-0,516619633 * *)\end{array}$ & $3,150 * *$ \\
\hline Prêmio do grão (PGRAO) & $\begin{array}{l}\text { Variação do } \\
\text { Preço Interno do } \\
\text { Óleo (DOLEO) }\end{array}$ & $0,387822141 * * *$ & $\begin{array}{c}1 \text { mês }(-0,570759662 * *) \\
5 \text { meses }\left(-0,516619633^{* *}\right)\end{array}$ & $3,150 * *$ \\
\hline Prêmio do grão (PGRAO) & $\begin{array}{l}\text { Variação do } \\
\text { Estoque no Brasil } \\
\quad \text { (DEBRA) }\end{array}$ & $-690,5080093 *$ & $\begin{array}{c}9 \text { meses }(573,0088527 * * *) \\
10 \text { meses }(-865,9513246 * *) \\
11 \text { meses }(614,4178494 * * *) \\
12 \text { meses }(-512,3383183 * * *)\end{array}$ & 0,915 \\
\hline Prêmio do grão (PGRAO) & $\begin{array}{l}\text { Variação do } \\
\text { Estoque na } \\
\text { Argentina } \\
\text { (DEARG) }\end{array}$ & 51,341751 & $\begin{array}{l}11 \text { meses }\left(1013,308238^{* *}\right) \\
12 \text { meses }\left(-1131,459635^{*}\right)\end{array}$ & 1,469 \\
\hline Prêmio do grão (PGRAO) & $\begin{array}{l}\text { Variação do } \\
\text { Estoque nos } \\
\text { Estados Unidos } \\
\text { (DEEUA) }\end{array}$ & $-4624,219238 * * *$ & $\begin{array}{c}3 \text { meses }(8163,897763 * *) \\
11 \text { meses }\left(-7739,690515^{* *}\right) \\
12 \text { meses }\left(8394,562715^{*}\right)\end{array}$ & $2,310 * *$ \\
\hline Prêmio do grão (PGRAO) & $\begin{array}{l}\text { Variação do } \\
\text { Preço Interno do } \\
\text { Farelo } \\
\text { (DFARELO) }\end{array}$ & $-1,45153495$ & $\begin{array}{l}7 \text { meses }(-10,24636637 * *) \\
10 \text { meses }(9,35438659 * *)\end{array}$ & $3,346^{*}$ \\
\hline
\end{tabular}


Tabela 24. Relações causais entre o prêmio e suas variáveis determinantes com dados mensais.

\begin{tabular}{|c|c|c|c|c|}
\hline De & Para & Contemporânea & $\begin{array}{c}\text { Defasagens } \\
\text { Significativas }\end{array}$ & Teste F \\
\hline Prêmio do grão (PGRAO) & $\begin{array}{c}\text { Percentual } \\
\text { exportado para } \\
\text { Ásia através do } \\
\text { porto de } \\
\text { Paranaguá } \\
\text { (ASIA) }\end{array}$ & $7,58960832 * * *$ & $\begin{array}{c}1 \text { mês }\left(12,85471189^{* *}\right) \\
2 \text { meses }\left(-12,42681016^{* *}\right) \\
5 \text { meses }(9,16142642 * *)\end{array}$ & $3,260 * *$ \\
\hline Prêmio do grão (PGRAO) & $\begin{array}{c}\text { Percentual } \\
\text { exportado para } \\
\text { Europa através do } \\
\text { porto de } \\
\text { Paranaguá } \\
\text { (EUROPA) }\end{array}$ & $-11,62985055$ & - & 0,291 \\
\hline $\begin{array}{l}\text { Premio do Grão } \\
\text { (PGRAO) }\end{array}$ & $\begin{array}{l}\text { Cotação } \\
\text { internacional do } \\
\text { petróleo } \\
\text { (PETRO) }\end{array}$ & $0,850768671^{* * *}$ & 1 mês $(-0,839605483)$ & 2,701 \\
\hline
\end{tabular}

Fonte: Dados da Pesquisa

* significativo a $1 \%$

$* *$ significativo a $5 \%$

*** significativo a $10 \%$

1/ Apesar do teste ter apontado a existência de relação causal do prêmio do grão (PGRAO) para os estoques nos Estados Unidos (DEEUA), esta relação está ligada ao caráter sazonal destas duas variáveis.

A Tabela 24 mostra que as variáveis relacionadas à disponibilidade de produto, tanto internamente quanto externamente, são importantes na explicação do prêmio. Também as rentabilidades de outras alternativas de comercialização, conforme mostradas nas tabelas 6 a 9, são importantes, principalmente àquelas relacionadas à comercialização do farelo de soja, tanto internamente quanto externamente. Já a comercialização do óleo de soja não apresentou relação causal com o prêmio do grão. Isto pode ser explicado pelo fato de as exportações de óleo representarem apenas 38\% (2001) do total produzido internamente. De maneira geral, pode-se esperar que quanto maior a importância do consumo interno de um produto, menor sua relação com os preços de internacionais, já que os preços internos desses produtos tendem a ficar acima da paridade de exportação e dependentes das oscilações na produção e demanda internas. 
Adicionalmente, foi testada a hipótese de bi-causalidade entre o prêmio do grão e os estoques no Brasil. Os testes mostraram que não há bi-causalidade entre o estoque e o prêmio, isto é, o prêmio não é capaz de alterar os estoques. Já a relação entre o prêmio do grão e o prêmio do farelo é bi-causal. As relações causais são exemplificadas através da Figura 25.

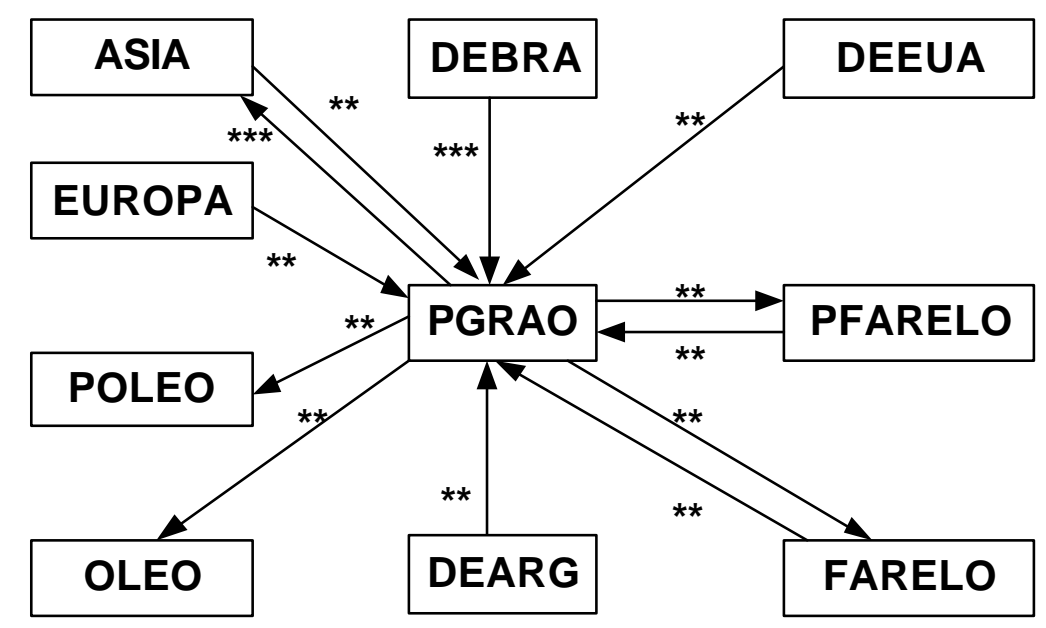

Figura 25 - Representação das relações causais entre os dados mensais determinantes do prêmio de exportação da soja.

* significativo a $1 \%$

** significativo a $5 \%$

$* * *$ significativo a $10 \%$

Além de apresentar as relações causais entre as variáveis relevantes na explicação do prêmio, a Figura 25 mostra que alterações no prêmio de exportação do óleo não alteram o prêmio de exportação do grão, reforçando a idéia de maior importância do mercado interno que do externo na comercialização do óleo. Contudo, percebe-se que variações no prêmio do grão alteram o prêmio do óleo. Isto pode ser explicado pelo fato de que quando há uma elevação do prêmio do grão, uma proporção maior da soja disponível tende a ser exportada na forma de grão, reduzindo a quantidade de soja 
esmagada e, por sua vez, reduzindo a quantidade de óleo disponível, tanto para consumo interno quanto para a exportação

As participações das exportações para a Ásia e Europa no total exportado através do porto de Paranaguá apresentam relação causal significativa com o prêmio de exportação do grão. No entanto, esta relação pode estar ligada ao fato de as exportações para estes destinos e o prêmio apresentarem forte caráter sazonal, isto é, as exportações ocorrem no período de safra, quando o prêmio é menor. Uma importante crítica ao teste de causalidade utilizando dados mensais consiste no fato de que, mesmo que o teste não seja significativo, não se pode rejeitar a hipótese de que a relação entre as variáveis seja bastante dinâmica, e a causalidade exista e se propague apenas no período de um mês.

As variáveis que apresentaram raiz unitária foram diferenciadas, para que todas aquelas utilizadas na regressão fossem estacionárias. Caso contrário, segundo Gujarati (1995), os valores dos testes apresentados poderiam estar viesados. Considerando-se o período de março de 1996 a março de 2002, tem-se os resultados observados nas tabelas 25 e 26. 
Tabela 25. Estimativa do prêmio em função das séries com dados mensais (com as defasagens determinadas no teste de causalidade) e teste da soma dos coeficientes.

\begin{tabular}{|c|c|c|c|c|c|c|c|c|c|c|c|c|c|}
\hline Regressor & $\mathrm{t}$ & $\mathrm{t}-1$ & $\mathrm{t}-2$ & $t-3$ & $\mathrm{t}-4$ & $t-5$ & $t-6$ & $\mathrm{t}-7$ & $\mathrm{t}-8$ & $\mathrm{t}-9$ & $\mathrm{t}-10$ & $\mathrm{t}-11$ & $\begin{array}{c}\text { Soma } \\
\left(\mathrm{H}_{0}=0\right)\end{array}$ \\
\hline Constante & $0,8396 * * *$ & & & & & & & & & & & & \\
\hline PGRAO & $0,4272 * * *$ & & & & & & & & & & & & $0,42722 * * *$ \\
\hline DEBRA & $-0,0005159^{*}$ & 0,00010 & $-0,000211$ & 0,000162 & $8,283 \mathrm{e}-05$ & 0,000163 & $-6,290 \mathrm{e}-05$ & $-8,453 \mathrm{e}-05$ & $8,040 \mathrm{e}-05$ & $8,520 \mathrm{e}-05$ & $-4,7 \mathrm{e}-08$ & 0,000067 & $-0,0001320$ \\
\hline DEEUA & $4,761 \mathrm{e}-06$ & $-5,894 \mathrm{e}-06$ & $-3,028 \mathrm{e}-05$ & $-2,253 e-05$ & $5,066 \mathrm{e}-06$ & $1,7355 \mathrm{e}-05$ & $1,4743 \mathrm{e}-05$ & $-1,207 e-05$ & & & & & $-0,0000390$ \\
\hline DEARG & $7,878 \mathrm{e}-06$ & $-9,526 e-5$ & $-2,566 \mathrm{e}-04 * * *$ & $7,466 \mathrm{e}-05$ & $2,058 \mathrm{e}-04 * * *$ & & & & & & & & $-0,0006244$ \\
\hline PFARELO & $0,0432 *$ & $-0,1256$ & 0,0045 & 0,0129 & 0,0041 & $-0,0082$ & 0,00047 & 0,0169 & & & & & $0,0614450 * *$ \\
\hline DFARELO & $-0,009457$ & $-0,005906$ & $-0,014621 * * *$ & 0,002626 & $-0,002142$ & $-0,008238$ & $-0,01467 * * *$ & & & & & & $0,0524117 * * *$ \\
\hline EUROPA & 0,001599 & $-0,002965$ & & & & & & & & & & & $-0,0013652$ \\
\hline ASIA & $-0,008951$ & $-0,005912$ & 0,005925 & $-0,00173$ & 0,0002830 & $-0,002829$ & $-0,005848$ & $-0,009092$ & & & & & $-0,0400158$ \\
\hline
\end{tabular}

Fonte: Dados da pesquisa

$\mathrm{R}^{2}=0,74$

$\mathrm{F}(51,10)=4,47$

$\mathrm{Q}(15)=14,79$

* significativo a $1 \%$

** significativo a $5 \%$

*** significativo a $10 \%$ 
Tabela 26. Estimativa do prêmio em função das séries com dados mensais com cinco defasagens e teste da soma dos coeficientes.

\begin{tabular}{|c|c|c|c|c|c|c|c|}
\hline Regressor & $\mathrm{t}$ & $\mathrm{t}-1$ & $t-2$ & $t-3$ & $\mathrm{t}-4$ & $t-5$ & $\begin{array}{c}\text { Soma } \\
\left(\mathrm{H}_{0}=0\right)\end{array}$ \\
\hline Constante & $-0,3853$ & & & & & & \\
\hline PGRAO & & $0,6934 * *$ & $-0,5477$ & 0,4856 & $-0,0531$ & 0,3270 & $0,9052 * * / 1$ \\
\hline DEBRA & $-2,0908 \mathrm{e}-04^{* *}$ & $6,9314 \mathrm{e}-05$ & $-1,0788 \mathrm{e}-04$ & $1,4599 \mathrm{e}-04$ & $6,9024 \mathrm{e}-05$ & $3,1047 e-05$ & $-1,59 \mathrm{e}-06$ \\
\hline DEEUA & $-1,1649 \mathrm{e}-05$ & $-1,8665 \mathrm{e}-05$ & $-2,2928 \mathrm{e}-05$ & $-8,2995 \mathrm{e}-06$ & $-8,5576 \mathrm{e}-06$ & $3,2703 \mathrm{e}-06$ & $-6,68 \mathrm{e}-05$ \\
\hline DEARG & $-1,0385 \mathrm{e}-04$ & $-5,0046 e-05$ & $-2,0182 \mathrm{e}-04 * * *$ & $2,3589 \mathrm{e}-05$ & $-1,7021 \mathrm{e}-04^{* *}$ & $1,1342 \mathrm{e}-04$ & $-3,89 e-04$ \\
\hline PFARELO & $0,0323 * *$ & $-0,0302 * *$ & 0,0184 & $-8,7937 \mathrm{e}-03$ & $7,3717 \mathrm{e}-03$ & $-5,5193 e-03$ & $1,36 \mathrm{e}-02$ \\
\hline DFARELO & $-9,6689 e-03$ & $1,1745 \mathrm{e}-03$ & $-6,3093 e-03$ & $1,7722 \mathrm{e}-03$ & $1,6881 \mathrm{e}-03$ & $-2,9381 \mathrm{e}-03$ & $-1,43 e-02$ \\
\hline EUROPA & $-1,0196 \mathrm{e}-03$ & 1,0791e-03 & $6,8681 \mathrm{e}-05$ & $3,1434 \mathrm{e}-03$ & $-2,3914 \mathrm{e}-03$ & $4,217 \mathrm{e}-03 * *=$ & $5,10 \mathrm{e}-03$ \\
\hline ÁSIA & $-8,4275 \mathrm{e}-03$ & $9,2050 \mathrm{e}-03$ & $5,4617 \mathrm{e}-04$ & $7,7529 \mathrm{e}-03$ & $2,6152 \mathrm{e}-03$ & $4,9543 e-03$ & $1,66 \mathrm{e}-02$ \\
\hline
\end{tabular}

Fonte: Dados da pesquisa

$\mathrm{R}^{2}=0,67$

$\mathrm{Q}(17)=14,14$

* significativo a $1 \%$

** significativo a $5 \%$

*** significativo a $10 \%$

/1 não difere estatisticamente de 1

Os resultados apresentados nos testes de causalidade, utilizando-se dados mensais, conforme apresentados na Tabela 25 e exemplificados na Figura 25, mostram quais variáveis dentre as testadas apresentam relação significativa com o prêmio de exportação do grão. As tabelas 25 e 26 mostram o resultado da regressão do prêmio com estas variáveis que se mostram relevantes nos testes de causalidade. Os resultados apresentados ms tabelas 25 e 26 mostram oscilação nos sinais das defasagens das variáveis explicativas. Desta forma, optouse por analisar o sinal da soma dos coeficientes. Utilizando-se a Tabela 26, nota-se que: 
a) Elevação nos valores passados do prêmio do grão tendem a elevar seu valor atual.

b) Aumento nos estoques no Brasil, Argentina e Estados Unidos tendem a reduzir o valor do prêmio em Paranaguá.

c) Elevação no prêmio do farelo de soja tendem a aumentar o prêmio do grão.

d) Incrementos no preço interno do farelo tendem a deprimir o prêmio do grão

c) Aumento na exportação de soja em grão tanto para a Europa quanto para a Ásia tendem a elevar o prêmio do grão.

Estes resultados estão em concordância com as hipóteses básicas discutidas inicialmente. Exceção apenas para a relação entre o preço do farelo no mercado interno e o prêmio de exportação. Esperava-se que aumentos no preço interno do farelo resultassem em elevação do prêmio do grão, o que não se verificou.

\subsection{Teste de causalidade entre as séries FOB e preços da soja em Maringá}

\subsubsection{Teste de Raiz Unitária}

Antes de realizar os testes de causalidade, é necessário definir a estacionariedade das séries, verificando a existência de raiz unitária. A Tabela 27 resume os resultados do teste de raiz unitária para as séries indicadas abaixo:

1. Preço da soja no mercado físico em Maringá, Paraná, (MAR)

2. Preço FOB para o primeiro embarque (FOBA)

3. Preço FOB para o segundo embarque (FOBB)

4. Preço FOB para o terceiro embarque (FOBC)

5. Preço FOB para o embarque mais próximo - "FOB spot" - (FOBD) 
Tabela 27. Resultado dos testes de Raiz Unitária para o preço da soja em Maringá, PR, e para as séries FOB.

\begin{tabular}{lcccccc}
\hline Variável & $\tau_{\tau}$ & $\tau_{\beta \tau}$ & $\tau_{\mu}$ & $\tau_{\alpha \mu}$ & $\tau$ & Defasagens \\
\hline MAR & $-2,38$ & $-1,58$ & $-1,81$ & 1,78 & $-0,33$ & $15^{* *}$ \\
DMAR & $-6,19^{*}$ & --- & --- & --- & -- & $14^{* *}$ \\
FOBA & $-2,60$ & $-2,38$ & $-1,27$ & 1,16 & $-0,67$ & $6^{* *}$ \\
DFOBA & $-5,36^{*}$ & --- & --- & --- & --- & $5 * *$ \\
FOBB & $-2,47$ & $-2,39$ & $-1,19$ & 1,09 & $-0,59$ & 5 \\
DFOBB & $-7,19 *$ & --- & --- & --- & --- & 5 \\
FOBC & $-2,27$ & $-2,18$ & $-1,13$ & 1,03 & $-0,62$ & 0 \\
DFOBC & $-17,39^{*}$ & --- & -- & --- & -- & 0 \\
FOBD & $-2,14$ & $-2,02$ & $-1,15$ & 1,04 & $-0,68$ & 1 \\
DFOBD & $-22,39^{*}$ & --- & --- & --- & --- & 0 \\
\hline
\end{tabular}

Fonte: Dados da pesquisa

* significativo a $1 \%$

** significativo a $5 \%$

Como observado na Tabela 27, todas as séries apresentam uma raiz unitária. Dessa forma, as variáveis deveriam ser utilizadas na diferença para que os resultados dos testes de causalidade sejam válidos. Contudo, os resultados dos testes de causalidade são mais facilmente interpretados utilizando-se o logaritmo das variáveis, o que, não altera significativamente os testes de raiz unitária anteriormente realizados, como mostrado na Tabela 28. 
Tabela 28. Resultado dos testes de Raiz Unitária para o preço da soja em Maringá, PR, e para as séries FOB, na forma logarítmica.

\begin{tabular}{lcccccc}
\hline Variável & $\tau_{\tau}$ & $\tau_{\beta \tau}$ & $\tau_{\mu}$ & $\tau_{\alpha \mu}$ & $\tau$ & Defasagens \\
\hline LMAR & $-2,48$ & $-1,66$ & $-1,86$ & 1,85 & $-0,15$ & $15^{* *}$ \\
DLMAR & $-6,20^{*}$ & --- & --- & --- & -- & $14^{* *}$ \\
LFOBA & $-2,70$ & $-2,54$ & $-1,19$ & 1,14 & $-0,62$ & $6^{* *}$ \\
DLFOBA & $-5,25^{*}$ & --- & --- & --- & --- & $5^{* *}$ \\
LFOBB & $-2,53$ & $-2,54$ & $-1,07$ & 1,03 & $-0,54$ & 5 \\
DLFOBB & $-7,27^{*}$ & --- & --- & --- & --- & $5^{* * *}$ \\
LFOBC & $-2,28$ & $-2,30$ & $-0,96$ & 0,92 & $-0,60$ & 0 \\
DLFOBC & $-17,05^{*}$ & --- & -- & --- & -- & 0 \\
LFOBD & $-2,17$ & $-2,13$ & $-1,03$ & 0,99 & $-0,64$ & 0 \\
DLFOBD & $-23,81^{*}$ & --- & --- & --- & --- & 0 \\
\hline
\end{tabular}

Fonte: Dados da pesquisa

* significativo a $1 \%$

** significativo a $5 \%$

$* * *$ significativo a $10 \%$

\subsubsection{Elasticidade de transmissão de preços}

Utilizando o logaritmo das variáveis na diferença, foram realizados os testes de causalidade. Os resultados mostram que todas as séries de preço FOB apresentaram relação causal com os preços observados em Maringá. Estes resultados estão sumarizados na Tabela 29. 
Tabela 29. Elasticidades de transmissão de preços da soja entre o preço de exportação (séries FOB) e o preço em Maringá, Paraná.

\begin{tabular}{cccc}
\hline Variável & Contemporânea & No Período & Teste F \\
\hline \multirow{2}{*}{ LFOBA } & $0,6187^{*}$ & 1 mês $\left(0,4262^{*}\right)$ & $5,67^{*}$ \\
& & 2 meses $\left(0,1722^{* *}\right)$ & \\
& & 3 meses $\left(0,1619^{* *}\right)$ & 3 mês $\left(0,1958^{* *}\right)$ \\
LFOBB & $0,3313^{*}$ & 2 meses $\left(0,1504^{* * *}\right)$ & $3,3677^{*}$ \\
& & 5 meses $\left(0,1734^{* *}\right)$ & $8,3820^{*}$ \\
LFOBC & $0,1788^{* *}$ & 1 mês $\left(0,2027^{*}\right)$ & $17,9944^{*}$ \\
\hline
\end{tabular}

Fonte: Dados da pesquisa

* significativo a $1 \%$

** significativo a $5 \%$

*** significativo a $10 \%$

Nota-se nos resultados apresentados na Tabela 29 que a relação mais significativa entre o preço de exportação (FOB) e o preço praticado em Maringá, Paraná, é a série FOBA, que representa os valores FOB da série 1, conforme definido na metodologia. Adicionalmente, foram realizados testes de causalidade no sentido preço em Maringá para as séries FOB, sendo que nenhuma série apresentou relação causal significativa, indicando que a relação entre o preço em Maringá e o preço FOB é unicausal, do preço FOB para o interno. Estas relações estão representadas na Figura 26. 


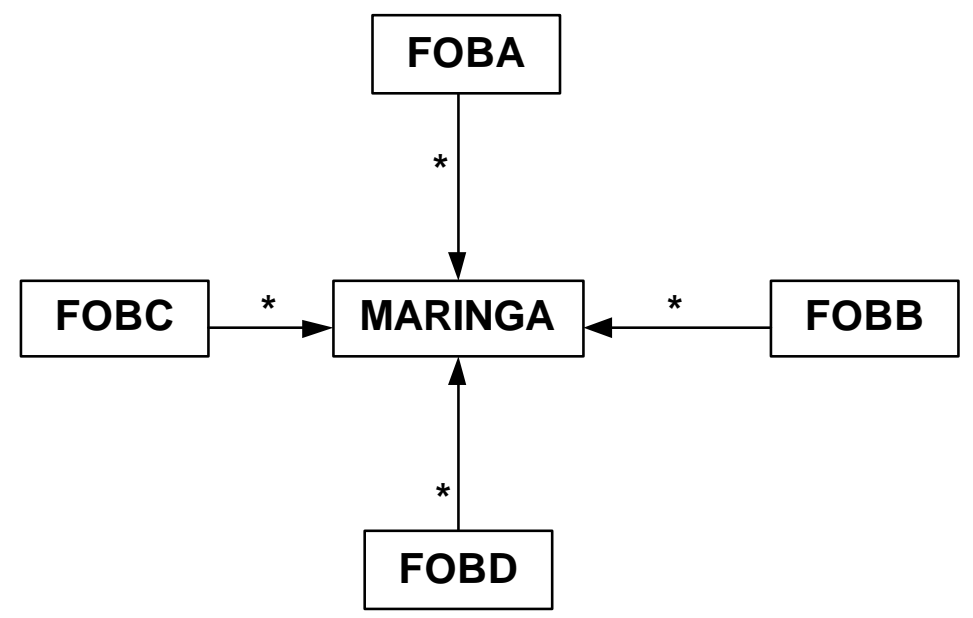

Figura 26 - Representação das relações causais entre os preços de exportação (séries FOB) e o preço da soja em dolar em Maringá.

* significativo a $1 \%$

** significativo a $5 \%$

Os resultados apresentados na Tabela 29 e resumidos na Figura 26 mostram que todas as quatro séries de preço FOB testadas possuem relação causal significativa com o preço interno. Este resultado confirma os resultados obtidos por Aguiar (1990), Mafioletti (2000), entre outros. Além de confirmar resultados anteriormente obtidos, a Tabela 29 mostra que a série de preços FOB A possui o maior valor da elasticidade de transmissão de preços $(0,6187)$. Isso indica que os preços de exportação referenciados no primeiro vencimento do contrato da soja na bolsa de Chicago possuem maior capacidade de explicar os preços internos, quando comparados àqueles das demais séries. 


\section{CONCLUSÕES}

O prêmio de exportação da soja brasileira é um fator que deve ser somado à cotação da bolsa de Chicago para se obter o preço recebido pelo exportador (FOB). O prêmio pode ser positivo, representando um ágio ou negativo, representando um deságio sobre as cotações do

produto na Bolsa de Chicago. É negociado entre importadores e exportadores de soja e representa um mecanismo para relacionar as cotações da CBOT e do mercado local. A participação do prêmio no preço recebido pelo exportador é significativa, chegando a elevá-lo em mais de $20 \%$ e reduzi-lo em até $5 \%$. Na negociação do prêmio, exportadores buscam o maior valor possível, enquanto os importadores procuram os menores valores possíveis. Da interação destes agentes é obtém-se o valor do prêmio.

O prêmio possui um caráter sazonal, com os maiores valores observados no período de entressafra e os menores no período de safra e exportação. Nesse período, os prêmios normalmente tornam-se negativos, isto é, o preço recebido pelo exportador fica abaixo das cotações da soja na bolsa de Chicago.

As variáveis significativas em explicar o prêmio de exportação da soja em grão estão ligadas à disponibilidade do produto e às alternativas de comercialização. Os estoques nos principais países produtores - Estados Unidos, Brasil e Argentina - alteram significativamente o valor do prêmio. Elevação nos estoques desses países tendem a reduzir o prêmio da soja pago em Paranaguá.

Representando as alternativas de exportação dos derivados da soja, os prêmios do farelo e do óleo apresentaram relação significativa e positiva com o prêmio, isto é, elevação no prêmio do farelo e do óleo eleva o prêmio do grão. Outras variáveis como a variação da 
taxa de câmbio e das cotações da soja na bolsa de Chicago, fretes internacionais (utilizandose como proxy o preço internacional do petróleo), não apresentaram relação causal significativa com o prêmio.

A partir dos valores de prêmio e das cotações na bolsa de Chicago foram construídas séries de preços recebidos pelos exportadores (preços FOB). Os preços da soja no mercado interno, tendo como referência Maringá, no Paraná, possuem relação causal significativa com os preços de exportação, sendo que para todas as séries o sentido causal é do preço de exportação para o preço interno. Os preços de exportação referenciados no primeiro vencimento dos contratos futuros da bolsa de Chicago mostram-se mais significativos em explicar o preço interno.

Este estudo exploratório mostrou as relações entre um conjunto de variáveis e o prêmio. Para o aprimoramento da identificação do mecanismo de formação do prêmio é necessária a criação de séries estatísticas de variáveis que podem influencia-lo e, a partir destas novas informações, comparar os resultados com outros métodos de análise. Propõe-se também a análise da diferença entre as cotações da bolsa de Chicago e o mercado interno, utilizando-se o preço de exportação mais significativo, conforme descrito neste trabalho, buscando-se verificar se os custos de exportação podem explicar a diferença entre o mercado local e a cotação na bolsa de Chicago. 


\section{REFERÊNCIAS BIBLIOGRÁFICAS}

AGUIAR, D.R.D. Formação de preços na indústria da soja - 1982/1989. Piracicaba, 1990. 140p. Dissertação (Mestrado) - Escola Superior de Agricultura "Luiz de Queiroz", Universidade de São Paulo.

ARGENTINA. Secretaria Agricultura, Ganadería, Pesca y Alimentación. Estimaciones Agricolas. Estimaciones Agrícolas. http://www.sagpya.mecon.gov.ar/agricu/informes/ semanal/estimac/estima.htm (25 Jul. 2002)

BARROS, G.S.A.C.; MARQUES, P.V.; BACCHI, M.R.P.; CAFFAGNI, L.C. Elaboração de indicadores de preços de soja: um estudo preliminar. Piracicaba: CEPEA/ESALQ/USP, abril de 1997.

BRASIL. Secretaria de comércio exterior. Balança comercial. http://www.mdic.gov.br/indicadores/estatistica.html (28 set. 2002)

CÂMARA, S.F.; MAIA, S.F.; LIMA, R.C. A formação de preços da soja no Brasil, uma visão sistemática considerando os efeitos de "feedback" em modelo do tipo VAR (compact disc). In: CONGRESSO BRASILEIRO DE ECONOMIA E SOCIOLOGIA RURAL, 38., Rio de Janeiro, 2000. Anais. Brasília: SOBER, 2000.

CANZIANI, J.R. GUIMARÃES, V.D.A. Cadeia produtiva da soja no Brasil. Curitiba: Universidade Federal do Paraná, Depto. de Economia Rural e Extensão, 2002. 113p.

DICKEY, D.A.; FULLER, W.A. Likelihood ratio statistics for autoregressive time series with a unit root. Econometrica, v.49, n.4, p.1057-1072, jul. 1981. 
DICKEY, D.A.; FULLER, W.A. Distribution of the estimators for autoregressive time series with a unit root. Journal of the American Statistical Association, v.74, n.366, p.427$431,1979$.

DAVIDSON, R.; MACKINNON, J.G. Estimation and inference in econometrics. New York: Oxford Economic Press, 1993. 874p.

ENDERS, W. Applied econometric time series. New York: John Wiley \& Sons, 1995. $433 p$.

ESTADOS UNIDOS. Department of Agriculture. Foreign agricultural service. http://www.fas.usda.gov/ (15 Sep. 2002)

ESTADOS UNIDOS. Department of Agriculture. National agricultural statistics service. http://www.usda.gov/nass/ (15 Sep. 2002)

FREITAS, S.M.; MARGARIDO, M.A.; BARBOSA, M.Z.; FRANCA, T.J.F. Análise da dinâmica de transmissão de preços no mercado internacional de farelo de soja no período de 1990/99 (compact disc). In: CONGRESSO BRASILEIRO DE ECONOMIA E SOCIOLOGIA RURAL, 38., Rio de Janeiro, 2000. Anais. Brasília: SOBER, 2000.

FULLER, W.A. Introduction to statistical time series. 2.ed. New York: John Wiley \& Sons, 1996. 698p.

GRANGER, C.W.J. Investigating causal relations by econometric models and cross spectral methods. Econometrica, v.37, n.3, p.424-438, 1969.

GUJARATI, D.N. Basic econometrics. 3.ed. New York: McGraw-Hill, 1995. 838p.

HOFFMANN, R. Análise de regressão: uma introdução à econometria. São Paulo: Hucitec, 1998. 379p.

HOFFMANN, R. Estatística para economistas. São Paulo: Pioneira, 1980. 379p.

HULL, J. Introdução aos mercados futuros e opções. São Paulo: BM\&F, 1996. 448p. 
MADDALA, G.S. Introduction to econometrics. 2.ed. New York: MacMillan, 1998. 472p.

MAFIOLETTI, R.L. Formação de preços na cadeia agroindustrial da soja na década de 90. Piracicaba, 2000. 95p. Dissertação (Mestrado) - Escola Superior de Agricultura "Luiz de Queiroz", Universidade de São Paulo.

MARGARIDO, M.A.; SOUSA, E.L.; BARBOSA, M.Z.; FREITAS, S.M. Transmissão de preços no mercado internacional de soja: uma aplicação da metodologia de séries temporais (compact disc). In: CONGRESSO BRASILEIRO DE ECONOMIA E SOCIOLOGIA RURAL, 38., Rio de Janeiro, 2000. Anais. Brasília: SOBER, 2000.

MARGARIDO, M.A.; SOUSA, E.L.L. Formação de preços da soja no Brasil (compact disc). In: CONGRESSO BRASILEIRO DE ECONOMIA E SOCIOLOGIA RURAL, 36., Poços de Caldas, 1998. Anais. Brasília: SOBER, 1998.

MARGARIDO, M.A.; MACHADO, E.L. Seasonal price analysis in soybean international market: the case of Brazil and Argentina (compact disc). In: CONGRESSO BRASILEIRO DE ECONOMIA E SOCIOLOGIA RURAL, 38., Rio de Janeiro, 2000. Anais. Brasília: SOBER, 2000.

MUROVA, O.; MUMMA, G.; HUDSON, D.; COUVILlION, W. Soybeans quality price differentials from an elevator's perspective. /Apresentado ao American Agricultural Economics Association, Tennessee, 1998/

PARCELL, J.L.; STIEGERT, K. Factors affecting wheat protein premiums. /Apresentado ao 1999 American Agricultural Economics Meetings, Tennessee, 1999/

TOSTO, S.G. Mercado interno de grãos de soja: modelos de equilíbrio e desequilíbrio. Piracicaba, 1996. 114p. Dissertação (Mestrado) - Escola Superior de Agricultura "Luiz de Queiroz”, Universidade de São Paulo. 


\section{APÊNDICES}


APÊNDICE 1 - Valores críticos das estatísticas $\hat{o}_{\hat{o}}$, $\hat{\mathrm{o}}_{\mathrm{i}}$ e ô para teste de raiz unitária.

\begin{tabular}{|c|c|c|}
\hline \multirow{2}{*}{$\begin{array}{l}\text { Tamanho da amostra } \\
n\end{array}$} & \multicolumn{2}{|c|}{ Probabilidade de um valor menor } \\
\hline & $1 \%$ & $5 \%$ \\
\hline & \multicolumn{2}{|c|}{$\hat{O}$} \\
\hline 25 & $-2,66$ & $-1,95$ \\
\hline 50 & $-2,62$ & $-1,95$ \\
\hline 100 & $-2,60$ & $-1,95$ \\
\hline 250 & $-2,58$ & $-1,95$ \\
\hline 500 & $-2,58$ & $-1,95$ \\
\hline \multirow[t]{2}{*}{$>$} & $-2,58$ & $-1,95$ \\
\hline & \multicolumn{2}{|c|}{$\hat{O}_{1}$} \\
\hline 25 & $-3,75$ & $-3,00$ \\
\hline 50 & $-3,58$ & $-2,93$ \\
\hline 100 & $-3,51$ & $-2,59$ \\
\hline 250 & $-3,46$ & $-2,88$ \\
\hline 500 & $-3,44$ & $-2,87$ \\
\hline \multirow[t]{2}{*}{$>$} & $-3,43$ & $-2,86$ \\
\hline & \multicolumn{2}{|c|}{$\hat{\mathrm{O}}_{\hat{\mathrm{o}}}$} \\
\hline 25 & $-4,38$ & $-3,60$ \\
\hline 50 & $-4,15$ & $-3,50$ \\
\hline 100 & $-4,04$ & $-3,45$ \\
\hline 250 & $-3,99$ & $-3,43$ \\
\hline 500 & $-3,98$ & $-3,42$ \\
\hline$>$ & $-3,96$ & $-3,41$ \\
\hline
\end{tabular}

Fonte: Enders (1995) 
APÊNDICE 2 - Valores críticos das estatísticas ôâô e ôầ.

\begin{tabular}{|c|c|c|}
\hline \multirow{2}{*}{$\begin{array}{l}\text { Tamanho da amostra } \\
n \\
\end{array}$} & \multicolumn{2}{|c|}{ Probabilidade de um valor menor } \\
\hline & $1 \%$ & $5 \%$ \\
\hline & \multicolumn{2}{|c|}{$\hat{\mathrm{O}}_{\hat{\mathrm{a}} \hat{\mathrm{o}}}$} \\
\hline 25 & 3,74 & 2,85 \\
\hline 50 & 3,60 & 2,81 \\
\hline 100 & 3,53 & 2,79 \\
\hline 250 & 3,49 & 2,79 \\
\hline 500 & 3,48 & 2,78 \\
\hline \multirow[t]{2}{*}{$>$} & 3,46 & 2,78 \\
\hline & \multicolumn{2}{|c|}{$\hat{\mathrm{o}}_{\text {áì }}$} \\
\hline 25 & 3,41 & 2,61 \\
\hline 50 & 3,28 & 2,56 \\
\hline 100 & 3,22 & 2,54 \\
\hline 250 & 3,19 & 2,53 \\
\hline 500 & 3,18 & 2,52 \\
\hline$>$ & 3,18 & 2,52 \\
\hline
\end{tabular}

Fonte: Dickey \& Fuller (1981) 